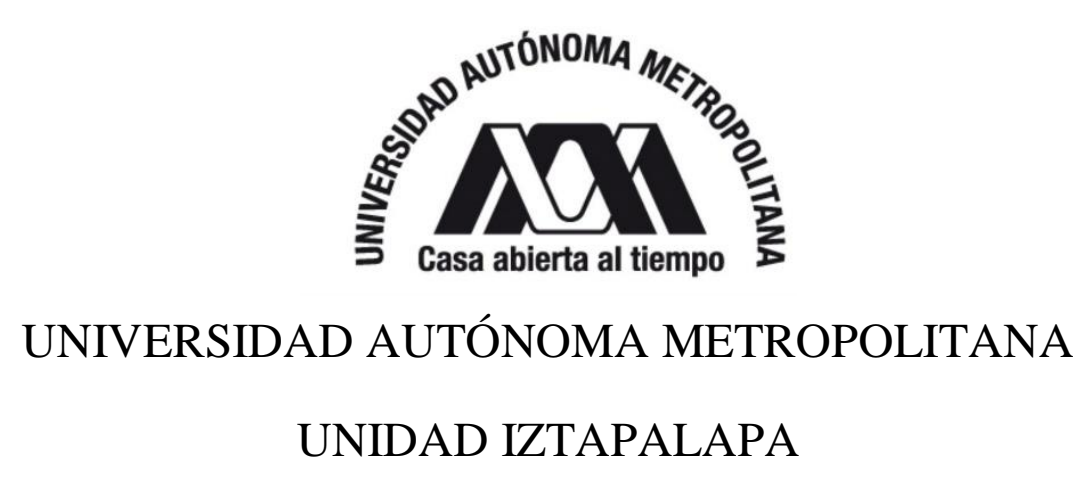

División de Ciencias Sociales y Humanidades

Posgrado en Humanidades

Línea de Lingüística

IDÓNEA COMUNICACIÓN DE RESULTADOS QUE

PRESENTA

DULCE MARIANA CORONEL AGUILAR

PARA OBTENER EL GRADO DE MAESTRA EN LINGÜÍSTICA

\title{
HABLAN BIBLIA: EL LENGUAJE RELIGIOSO DE LOS CRISTIANOS MÁS ALLÁ DE LA BIBLIA Y DEL TEMPLO
}

ASESORA: DRA. LAURA ADRIANA HERNÁNDEZ MARTÍNEZ

\section{LECTORES:}

DRA. MARÍA DEL REFUGIO PÉREZ PAREDES

MTRO. ROBERTO AGÚNDEZ MÁRQUEZ

Ciudad de México, enero de 2019 


\section{ÍNDICE}

Pág.

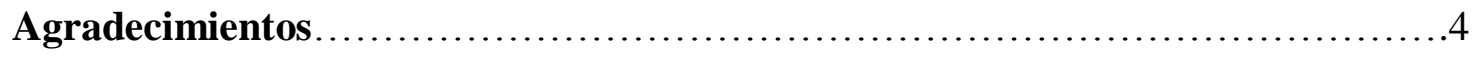

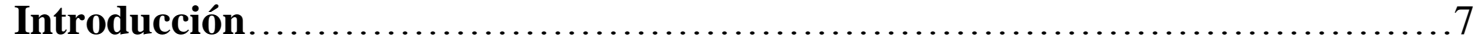

I. Breve planteamiento histórico-conceptual.............................20

1.1 ¿Qué es el cristianismo? Un seguimiento histórico.......................21

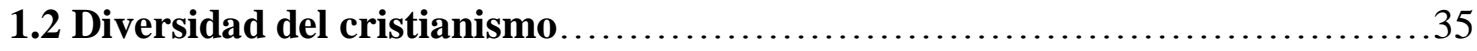

II. Marco teórico ......................................................46

2.1 Unidad de análisis: el enunciado.....................................46

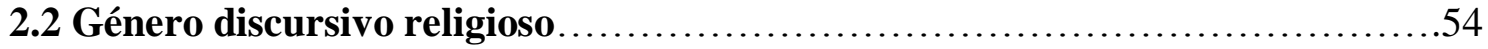

III. Los distintos soportes del lenguaje del cristianismo $\ldots \ldots \ldots \ldots \ldots \ldots \ldots \ldots \ldots . \ldots \ldots$

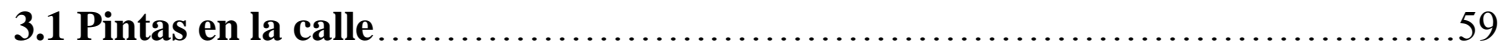

3.2 Tratados Chick ..................................................... 75

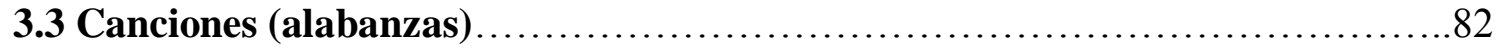

Conclusiones......................................................... 90

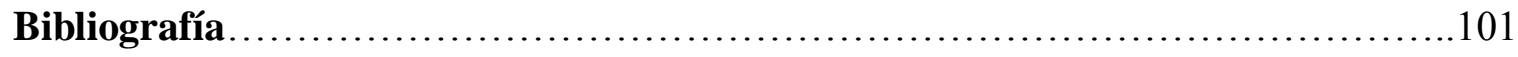




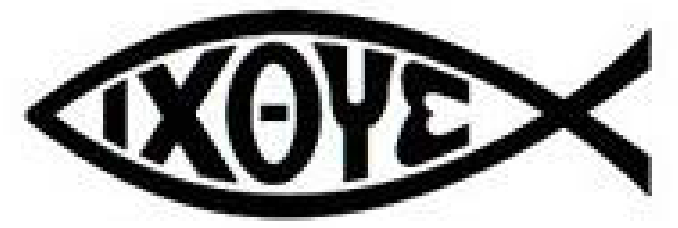

El fruto de mi investigación se lo dedico íntegramente a mi padre eterno, Dios, pues sin él no puedo hacer absolutamente nada, él es la fuente de todo lo que soy. Al ver el resultado final sólo puedo decir: ¡Gloria a Dios! 


\section{In Memoriam}

De mi amado Tío, José Luis Aguilar Luna 


\section{Agradecimientos}

En primer lugar, le agradezco a Dios por haberme permitido existir, le agradezco por su infinito amor y misericordia. Le doy las gracias porque, aún sin saberlo, en cada instante de la maestría me apoyó y me fortaleció cuando más lo necesitaba, me abrió paso cuando los caminos se cerraban. Sin duda alguna, todo se lo debo a él, todas las líneas de esta investigación le pertenecen íntegramente.

La vida de una persona se vive en distintos ámbitos cómo el espiritual, el familiar, el personal y el académico. En cada uno de ellos se encuentran personas a las cuales les tengo un profundo agradecimiento por su apoyo. En el plano espiritual le agradezco en primera instancia a Dios por haberme encontrado y haberme permitido ser una hija suya. Le agradezco a mi amado tío, José Luis Aguilar Luna $\uparrow$ por haber sido el instrumento que Dios utilizó para lograrlo. Siempre vivirás en mi corazón.

Dentro de mi esfera familiar, quiero agradecer y hacer mención especial a mi mamá, María de Lourdes Aguilar Luna, mi papá, Héctor Coronel Villegas y mi pequeño hermano, Héctor Coronel Aguilar. Su compañía y ejemplo de vida me incentivaron siempre a ser una mejor persona, a esforzarme cuando ya no podía más, encontré en sus palabras una razón más para vencer mis miedos y limitaciones. Les agradezco su amor infinito, su confianza, su apoyo incondicional, los esfuerzos y sacrificios que emprendieron para ayudarme a concluir este sueño, a ellos, siempre mi gratitud y mi amor. Espero que este trabajo sea una prueba de que todo valió la pena. Una cosa es segura, las palabras no logran reflejar lo que siento por ustedes, espero que mis hechos si lo hagan. 
Académicamente hablando, le debo mi gratitud a todos los profesores que conforman el posgrado en humanidades, de cada uno de ellos me llevo sus valiosos comentarios dados en los seminarios de investigación. Le agradezco, especialmente a mi asesora, la Dra. Laura Adriana Hernández Martínez por guiarme no sólo en la elaboración de esta investigación, sino por mostrarme en cada una de sus clases que se puede hacer lingüística desde diferentes perspectivas. Gracias por enseñarme que siempre hay temas novedosos listos para ser aprehendidos por nuestra perspectiva lingüística, sin renunciar a nuestros gustos personales. Esta investigación es la prueba de esta enseñanza. Gracias por ayudarme a plasmar este sueño.

También quiero hacer un énfasis en la ayuda que me proporcionaron cada uno de mis lectores. A la Dra. María del Refugio Paredes, por su constante apoyo en el ir y venir de esta investigación. Al Mtro. Roberto Agúndez, por enseñarme en los eventos académicos que compartimos, que la antropología y la lingüística pueden hacer una bonita e interesante mancuerna, gracias por las horas invertidas en este proyecto. Al Dr. Carlos Garma, le quiero agradecer todo el apoyo brindado hacia mi persona, al conocerlo me ha contagiado de su gran entusiasmo por la investigación, cada asesoría y coloquio compartido me incentivo a profundizar en esta fascinante temática. A todos ellos, mi eterna gratitud.

A la Universidad Autónoma Metropolitana, Unidad Iztapalapa, mi alma mater, le tendré siempre un profundo agradecimiento por permitirme desarrollarme académica y personalmente, los años que pase en sus aulas me forjaron como lingüista y persona. Mis agradecimientos no estarían completos sin mencionar al Consejo Nacional de Ciencia y Tecnología (CONACYT) por brindarme la oportunidad de realizar mis estudios de posgrado. 
A mis colegas del posgrado, Jessica, Claudia, Ángeles, Andrés, Rocío, Enrique, Jorge, Tania y Yúrik, el tiempo compartido en las aulas y fuera de ellas fueron parte integral de esta aventura llamada maestría.

Por último, quiero darle mi especial agradecimiento a David, quién se encuentra presente en cada uno de los ámbitos que mencioné. Estoy sumamente agradecida con él, porque siempre me apoyó y confió en mí, en todo momento me hizo sentir la persona más especial. Gracias por su amor, confianza y comprensión. Cada vez que estuve a punto de rendirme siempre me sostuvo con una palabra, con su sonrisa y con su mano extendida lista para levantarme y animarme a seguir hasta terminar.

Espero que esta investigación se convierta en un material de apoyo para todos aquellos aventureros que quieran acercarse a nuevas formas de hacer lingüística, antropología, etnografía y a la Palabra de Dios. 


\section{Introducción}

La muerte y la vida están en poder de la lengua, y el que la ama comerá de sus frutos.

Proverbios 18:21

Mi investigación está encaminada a estudiar la manera en que la Biblia pasa al lenguaje de los cristianos, es decir, cómo el lenguaje religioso sobrepasa el espacio habitual e histórico de la iglesia. En otras palabras, estudiar la relación entre un texto que no puede cambiar (la Biblia) y diferentes prácticas culturales que se encuentran encaminadas a propagar el mensaje bíblico. Normalmente, se entiende que la religión tiene un espacio determinado que no puede invadir otras esferas de la vida, sin embargo, si reflexionamos al respecto de esto, nos daremos cuenta de que un texto como la Biblia tiene presencia en la vida cotidiana, incluso para personas que no son creyentes. Por ejemplo, una frase como: "Me lavo las manos" (que se refiere a deslindarse de cualquier responsabilidad) remite a un pasaje bíblico (Mateo 27:24) y puede ser entendido por cualquier persona. Otro ejemplo, "lo crucificaron en la tesis" (denota que la persona que presentó la tesis fue muy criticada por su audiencia) alude a un pasaje bíblico (Mateo 15). La frase "todo tiene su tiempo" (hace referencia a que no hay que forzar las cosas) refiere a un pasaje bíblico (Eclesiastés 3). Por último, la frase "nadie es profeta en su propia tierra" tiene origen en el pasaje bíblico de Lucas 4:24 (da la idea de que la persona no puede triunfar en su lugar de origen). Como nos podemos dar cuenta existe presencia de la Biblia en el lenguaje coloquial.

De este modo, mi hipótesis es la siguiente: Tradicionalmente, el discurso religioso de los cristianos se constreñía al espacio privado y a la lectura de un libro religioso. En la actualidad, dicha situación ha cambiado, en tanto el lenguaje religioso se ha trasladado al 
espacio público y a la cultura popular, produciendo nuevos discursos y nuevas escrituras que seguirían considerándose religiosos.

Antes de continuar, es necesario establecer lo que entiendo por práctica cultural, tomando las palabras del antropólogo Ángel Díaz: “[...] significa que se desenvuelve necesariamente con tres condiciones. Es una acción hecha por alguien en concreto, es una acción hecha en algún lugar concreto, es una acción en el tiempo concreto de una vida." De acuerdo con lo anterior, la religión cristiana se puede considerar como una práctica cultural que está ligada a un lugar concreto, la iglesia; el creyente es el que la realiza en un tiempo determinado cuando se congrega. El discurso de esta práctica religiosa tiene su base en la Biblia, no obstante, sobrepasa los muros del templo generando una relación con otro tipo de discursos, llegando a tener presencia en otras prácticas que conforman la vida cotidiana del cristiano.

Desde esta perspectiva analítica, mi objeto de estudio son los cristianos, específicamente, su manera de construir un discurso sobre la interpretación que hacen de la Biblia (Palabra de Dios), este discurso se puede ver en la serie de enunciados presentes en mi corpus (Pintas en la calle, Tratados Chick, alabanzas² ${ }^{2}$, de modo que estudiaré el lenguaje que van construyendo y utilizando en su vida cotidiana, a partir de esta interpretación. Es decir, parto del texto sagrado de los cristianos desde el cual se construye un lenguaje muy particular, propio de este grupo social. En este planteamiento se conjugan distintos factores que trabajan en conjunto y determinan el desarrollo de mi investigación. En primer lugar identifico la existencia de un lenguaje religioso qué surge de la Biblia, éste normalmente

\footnotetext{
1 Á. Díaz de Rada, Cultura, antropología y otras tonterías, Madrid,Trotta, 2010, p.82.

${ }^{2}$ Cada elemento lo detallaré posteriormente.
} 
tiene sentido en el espacio del templo, sin embargo, al salir de esta esfera se convierte en un lenguaje anómalo, el cual podemos decir que es una especie de jerga ${ }^{3}$, debido a que se produce en situaciones cotidianas de la vida del creyente, otorgándole una identidad como cristiano. Después del análisis de mi corpus podré determinar si este lenguaje puede ser considerado coloquial o no, en su forma textual u oral.

Cabe señalar que esta perspectiva de estudio nació de una investigación previa que realicé en la licenciatura, en ese entonces mi interés se centraba en un análisis lexicográfico de los símbolos que aparecían en las parábolas de la Biblia, específicamente en el Nuevo Testamento. Ese análisis lo realicé para poder entender y comprobar el significado metafórico de los símbolos bíblicos. Para realizar el análisis lexicográfico mis herramientas principales fueron la Concordancia Strong, así como los diccionarios bíblicos de W. E. Vine, titulados: Diccionario expositivo de palabras del Antiguo y del Nuevo Testamento. Exhaustivo y la obra editada por Wilton N., Nelson, titulada: Diccionario ilustrado de la Biblia.

Para que el lector entienda lo que es la Concordancia Strong puedo agregar que, fue escrita en 1890 por el Dr. James Strong (1822-1894), profesor de teología exegética en el seminario teológico de la Universidad Drew, ubicada en New Jersey, Estados Unidos de América; dedicó su vida al estudio de las lenguas antiguas y al análisis exhaustivo de la Biblia. El título original del texto fue The Exhaustive Concordance of the Bible: Showing Every Word of the Text of the Common -English Version of the Canonical Books, and Every Occurrence Of Each Word in Regular Order; together with a Comparative Concordance of the Authorized and Revised Versions, including the American Variations; also brief

\footnotetext{
${ }^{3}$ Este concepto lo definiré en otro apartado del texto.
} 
Words, (véase imagen 1).

Imagen 1. Portada de la versión original escrita en 1890.

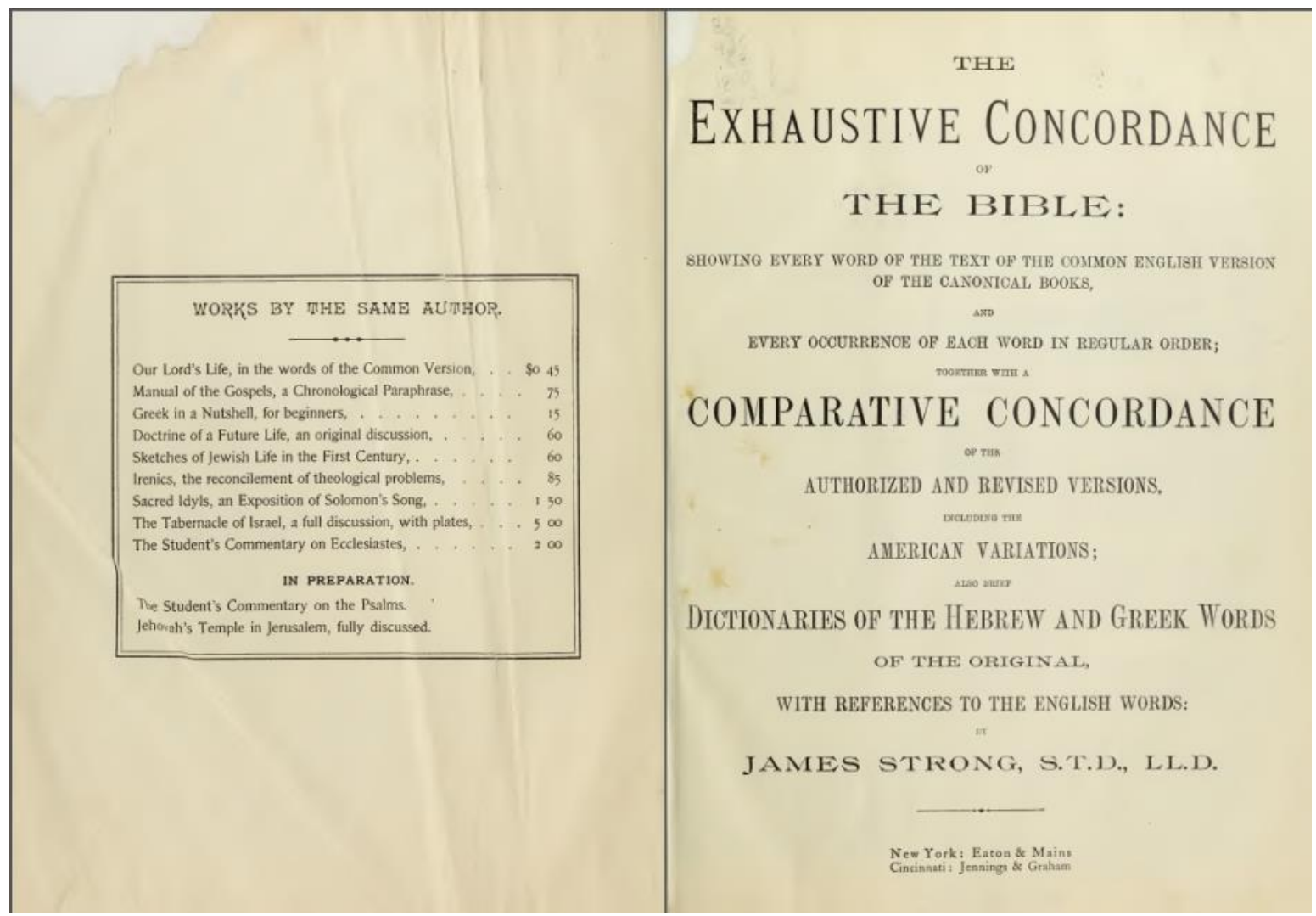

Cabe señalar que utilicé una versión traducida y editada al español en el año 2002 por

la Editorial Caribe, (véase imagen 2). ${ }^{4}$

\footnotetext{
${ }^{4}$ Mi ejemplar lo conseguí en una librería cristiana llamada Sociedad Bíblica de México de la Ciudad de México, pero es muy difícil conseguirla, incluso en las librerías cristianas especializadas en la exégesis.
} 

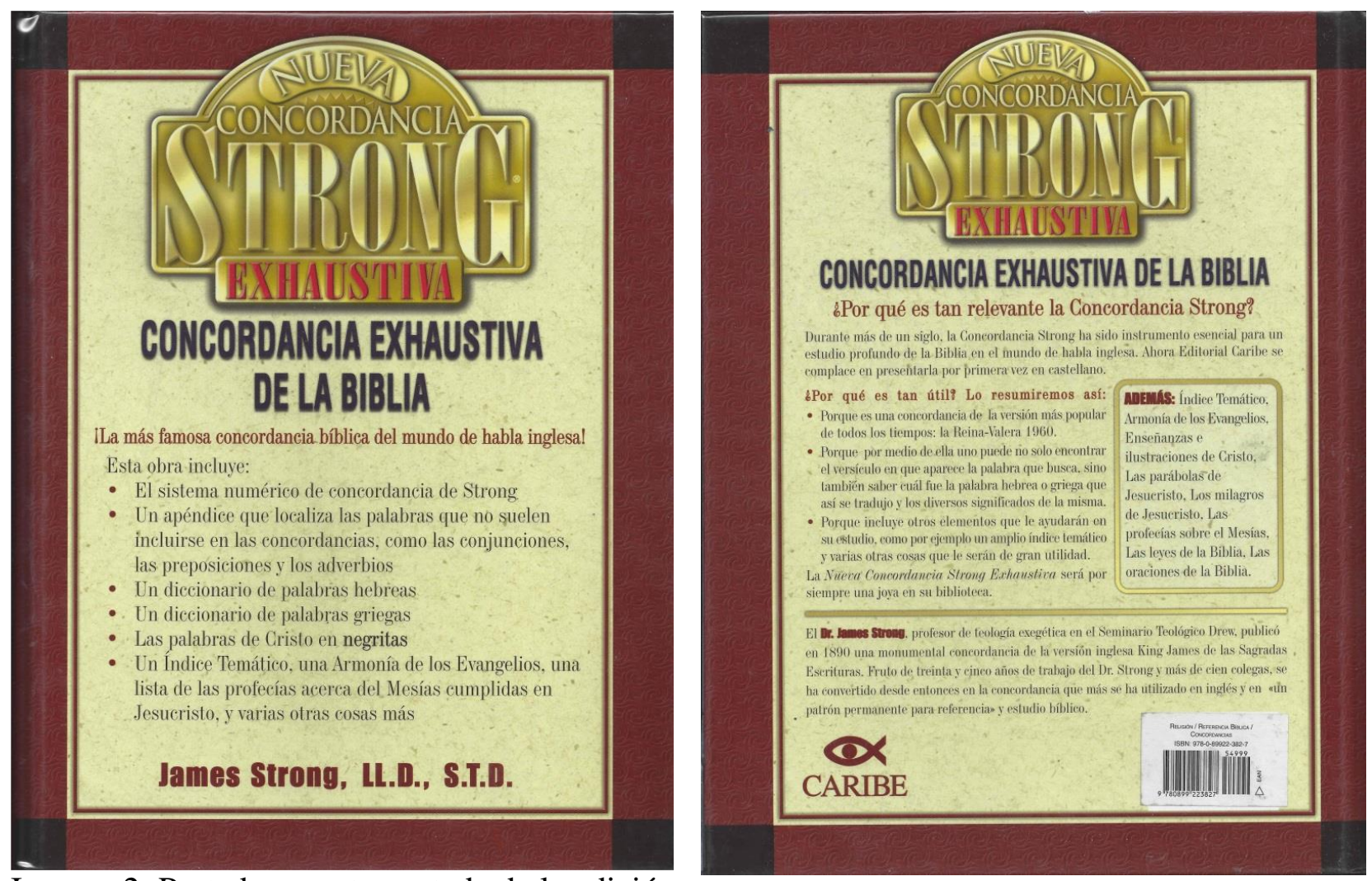

Imagen 2. Portada y contraportada de la edición de 2002.

Al igual que la original, ésta cuenta con tres diccionarios integrados del hebreo, el arameo y el griego, debido a que la Biblia fue escrita originalmente en estos tres idiomas, ${ }^{5} \mathrm{y}$ la concordancia al dar definiciones en el contexto original nos remite a alguno de estos diccionarios. En mi trabajo para obtener la licenciatura, analicé los símbolos de la parábola del Nuevo Testamento titulada "Los dos cimientos", porque incluye distintos términos que bajo el contexto del cristianismo tiene un significado especial. La parábola analizada fue la siguiente:

7:24 Cualquiera, pues, que me oye estas palabras, y las hace, le compararé a un hombre prudente, que edificó su casa sobre la roca.

\footnotetext{
${ }^{5}$ El Nuevo Testamento fue escrito en griego, en el caso del Antiguo Testamento hay una diferencia entre palabras en arameo y hebreo, los libros Esdras 4,8-6,18; 7,12-26, Daniel 2,4-7, 28, Génesis 31,47 (dos palabras), Jeremías 10,11 están en arameo y los demás libros están escritos en hebreo.
} 
7:25 Descendió lluvia, y vinieron ríos, y soplaron vientos, y golpearon contra aquella casa; y no cayó, porque estaba fundada sobre la roca.

7:26 Pero cualquiera que me oye estas palabras y no las hace, le compararé a un hombre insensato, que edificó su casa sobre la arena;

7:27 y descendió lluvia, y vinieron ríos, y soplaron vientos, y dieron con ímpetu contra aquella casa; y cayó, y fue grande su ruina.

7:28 Y cuando terminó Jesús estas palabras, la gente se admiraba de su doctrina;

7:29 porque les enseñaba como quien tiene autoridad, y no como los escribas. ${ }^{6}$

Las palabras subrayadas (roca, lluvia, ríos, vientos, arena y casa) dentro del contexto bíblico utilizado por los cristianos, pueden ser vistas como el criptograma de una idea, debido a que su significado no es explícito, y en ello radica la importancia de descifrar palabra por palabra. Elegí estas palabras por ser las que denotan mayor simbolismo. No hay que olvidar que bajo la visión del cristiano: “[...] en un texto inspirado por Dios nada puede quedar librado al azar y lee la Biblia como un libro de parábolas sagradas, escrito en un lenguaje simbólico peculiar."7

El método que seguí fue el siguiente: en primer lugar, identifiqué la palabra a estudiar, en este caso, río. El primer paso es buscarla en la Concordancia Strong, identificando el versículo donde aparece la palabra; adicionalmente se busca un contexto parecido al que se está estudiando, con el fin de encontrar y hacer más fácil la interpretación; en este caso Apocalipsis 12:15 es el que muestra un contexto más acorde con las necesidades interpretativas de la palabra estudiada: “12:15 Y la serpiente arrojó de su boca, tras la mujer, agua como un río, para que fuese arrastrada por el río.”

La Concordancia principal me remite a un número del diccionario en griego (4215),

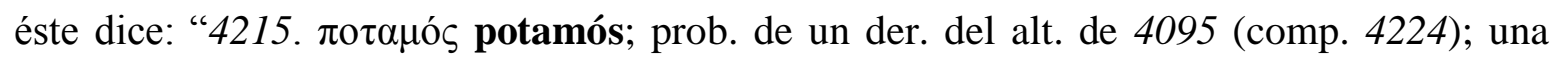

\footnotetext{
${ }^{6}$ Mateo 7:24-29. En las ediciones de biblias cristianas es común encontrar el texto en color rojo cuando se trata de palabras pronunciadas por Jesús.

${ }^{7}$ Roberto Bascom, Daniel Bonilla, et al., «Enseñaba por parábolas... »Estudio del género «parábola »en la Biblia, México, Editado por Edesio Sánchez Cetina, 2003, p. 31.
} 
corriente, arroyo o riachuelo (como bebible), i.e. agua corriente:-río." ${ }^{8}$ Conociendo el significado original en griego es posible reconocer el uso original de la palabra. En este caso, el río cómo corriente es el significado de mayor importancia para la interpretación. Como nos podemos dar cuenta, la utilidad de la Concordancia Strong radica en que simplifica el trabajo de buscar una palabra específica en todos los libros que conforman la Biblia.

Con el fin de encontrar más pistas para resolver el misterio interpretativo, el segundo paso que se realiza es consultar los diccionarios de W. E. Vine y W. M. Nelson. Una vez que revisé las tres obras que ya mencioné, procedo a la interpretación. Con los elementos que se encontraron en el contexto de la Concordancia Strong se puede identificar que la frase: "Y la serpiente arrojó de su boca, tras la mujer agua como un río[...],"9 tiene el mismo número de referencia que el versículo que se estoy analizando. Para entender íntegramente esta frase se tiene que identificar quién es la serpiente y qué es lo que arroja. Para poder responder a la primera pregunta, hay que apoyarse en el siguiente versículo: “12:9 Y fue lanzado fuera el gran dragón, la serpiente antigua, que se llama diablo y Satanás, el cual engaña al mundo entero; fue arrojado a la tierra, y sus ángeles fueron arrojados con él."10 Con lo anterior, es posible afirmar que la serpiente es Satanás. La respuesta de la segunda pregunta tiene que ver con la idea de que ninguna serpiente arroja agua por su boca, por lo que se infiere que cuando se habla de agua, se trata de un símbolo y se deduce que si las serpientes arrojan veneno y Satanás es un ser engañador y tentador, él arroja este veneno a los hombres, provocando que realicen acciones en conjunto, dado que Satanás puede engañar a una o a

\footnotetext{
8 James Strong. Nueva concordancia STRONG EXHAUSTIVA, Nashville/Dallas/México/Río de Janeiro/Beijing, Grupo Nelson, 1890/2002, p. 70.

${ }^{9}$ Apocalipsis 12:15.

${ }^{10}$ Apocalipsis 12:9.
} 
muchas personas. Para redondear la interpretación se toma en cuenta el concepto de corriente (Strong, Vine y Nelson), deduciendo que se trata de un símbolo que representa a una muchedumbre de personas.

Siguiendo el método anterior y revisando cada una de las obras mencionadas repetidamente, se llega a la interpretación de todos los símbolos incluidos en la parábola "Los dos cimientos". A continuación presento una tabla donde se pueden observar los símbolos (las palabras analizadas) con su respectivo significado bajo el contexto de la parábola ya referida:

\begin{tabular}{|c|c|}
\hline Misterio & Significado \\
\hline ROCA & Jesucristo \\
\hline LLUVIA & Pruebas \\
\hline RÍOS & Muchedumbre de personas \\
\hline CASA & Confiar en sí mismo \\
\hline ARENA & Tentaciones \\
\hline VIENTO & \\
\hline
\end{tabular}

Con todo lo anterior, resulta posible dar una interpretación de la parábola, el sentido revelado es el siguiente: “Cualquier persona que oye y hace la voluntad de Dios escrita en la Biblia es considerado un hombre prudente que edificó su fe sobre Jesucristo, fue capaz de soportar las pruebas, la muchedumbre de personas y tentaciones, su fe no cayó porque estaba fundada sobre Jesucristo. Pero cualquier persona que oye, pero no hace la voluntad de Dios, es considerado un hombre insensato que edificó su fe sobre sí mismo y no pudo soportar las pruebas, la muchedumbre de personas y las tentaciones por lo que cayó y fue grande su ruina." 
Así, llegué a la conclusión de que los cristianos entendían y usaban estas palabras de manera usual por lo que determine que usaban una jerga muy particular. Esto último determinó el alcance de mis resultados anteriores, es decir, reconocer símbolos y palabras especiales que se encontraban en las parábolas y determinar su significado con la ayuda de la concordancia y los diccionarios bíblicos.

En aquella ocasión terminé mi trabajo académico incluyendo un ejemplo de apropiación de los símbolos bíblicos, específicamente, el caso de los cristianos de la Congregación Metro Christian Center ubicada en Brooklyn, Nueva York. Esta congregación fue fundada por los pastores Tony Lara y Gladys Lara, que forman parte de la Metro World Child, considerada la escuela dominical más grande del mundo. Sus congregantes jóvenes crearon un ideograma ${ }^{11}$ (véase imagen 3 ) expresado en un grafiti que resume la doctrina cristiana:

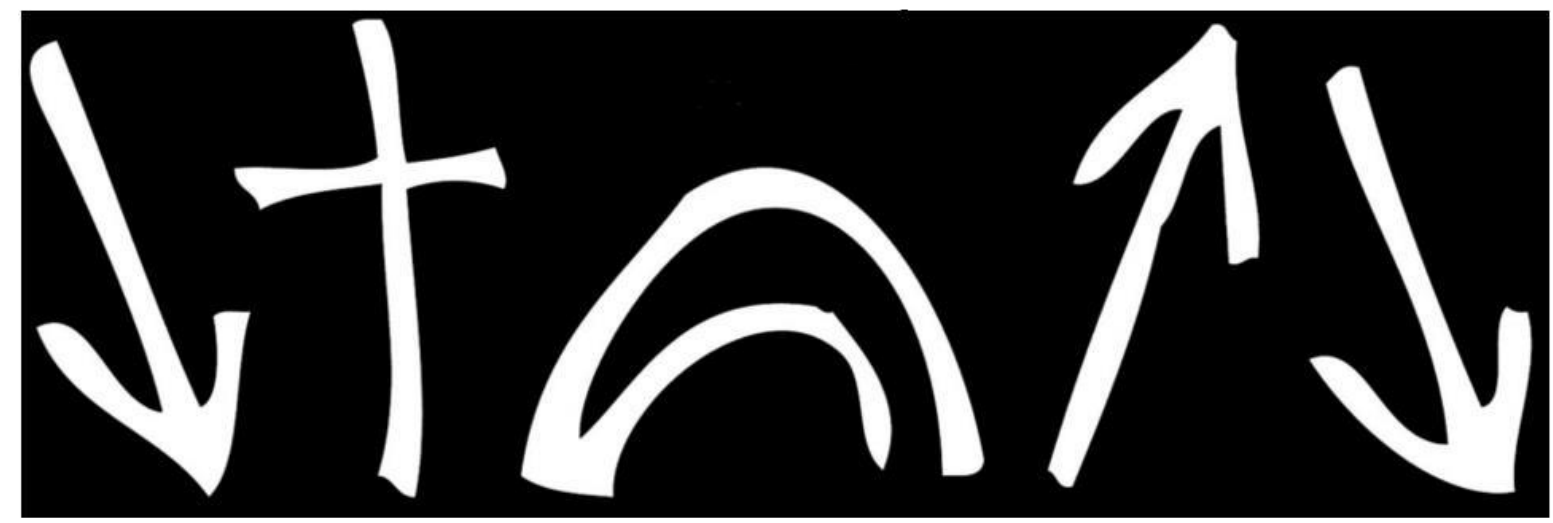

Imagen 3. Ideograma cristiano ${ }^{12}$

\footnotetext{
${ }^{11}$ Entendido como: "un símbolo que representa un concepto", Cfr. George Yule, El lenguaje, Madrid, Akal, 2008, p.301.

${ }^{12}$ Tomado de http://metrochristiancenter.org/hispano/\#intro-es (consultado el 20 de febrero de 2016).
} 
Cada símbolo representa una enseñanza bíblica, el primero de ellos la primera venida de Cristo al mundo; el segundo la muerte de Jesús; el tercero, que está en forma de cueva, da la idea de que Jesús resucitó, lo cual se conecta con el cuarto símbolo que representa el ascenso de Cristo al cielo; por último, el quinto símbolo denota la segunda venida de Cristo al mundo. Bajo la perspectiva cristiana, los cuatro primeros símbolos hacen referencia a acontecimientos que ya sucedieron, no obstante el quinto símbolo se identifica con un suceso que todavía no ha pasado, pero que todo cristiano espera. En suma, los símbolos en conjunto son la síntesis de la fe cristiana.

La difusión de este ideograma forma parte de la campaña de evangelización permanente que realizan los jóvenes de esta congregación en las calles, especialmente en las lineas del metro donde realizan grafitis, pegan calcomanías y reparten volantes. Todo con el fin de socializar la doctrina cristiana. Este ejemplo es ilustrativo para la versatilidad de apropiación, transformación y llegada de los símbolos bíblicos a otros contextos fuera de la iglesia. Estos resultados me ayudaron a definir el camino de mi investigación actual, en la que me interesa analizar el salto de los mensajes bíblicos desde la Biblia hacia diferentes soportes, es por ello que me enfocaré en primera instancia en las pintas de la calle, también en los Tratados Chick y en las alabanzas (canciones). Todas estas expresiones del mensaje bíblico tienen presencia en la vida del cristiano, puesto que, desde su cosmovisión su fe forma parte integral de su estilo de vida. Estas manifestaciones nacen de su texto sagrado pero no se limita a esa esfera social. Para ahondar en la explicación de este tipo de lenguaje me referiré a lo que Wittgenstein considera al respecto, cuando señala que la característica más importante del lenguaje religioso radica en que sólo funciona en un contexto determinado, el religioso, el cual se encuentra en un plano diferente al de la razón, en tanto se encuentra 
anclado en las creencias de una persona: "No es cuestión de que estemos cerca o no en alguna parte, sino de que su propio planteamiento se realiza en un plano completamente diferente [...]"13 Para un creyente la importancia de su discurso no está en la armonía de sus argumentos o razones, las cosas que creen, simplemente son verdad: "En un discurso religioso usamos expresiones como: «creo que sucederá tal y tal cosa», pero no las usamos del mismo modo que las usamos en la ciencia $[\ldots]$ la gente que tiene fe no aplica la duda que ordinariamente aplicaría a cualquier proposición histórica."14

En este sentido, los cristianos no se preocupan por normar su discurso con el del lenguaje estándar, debido a que los símbolos que aparecen cotidianamente en sus expresiones tienen una lógica interna que justifica su utilización. En las prácticas sociales de este grupo es posible observar la dinámica de convivencia existente entre las esferas de los lenguajes estándar y religioso, donde se comunican lo sacro y lo profano.

Antes de dar cuenta de la organización de los capítulos de mi investigación quiero ocuparme de una cuestión epistemológica relevante, me refiero a mi pertenencia al cristianismo, lejos de ser una limitación, me permite realizar mi investigación desde dos perspectivas: la emic $^{15}$ y la etic. ${ }^{16}$ Considero que, particularmente para el tema de mi investigación, la combinación de ambas perspectivas resulta benéfico para el análisis, pues al enfrentarme a las prácticas cristianas, como el uso de versículos bíblicos y palabras

13 Ludwig Wittgenstein, Lecciones y conversaciones sobre estética, psicología y creencia religiosa, Barcelona/Buenos Aires/México, Ediciones Paidós/Universidad Autónoma de Barcelona, 1992, p. 129.

${ }^{14}$ Ibíd.,pp. 133-134.

${ }^{15}$ Percepción de los propios miembros del objeto de estudio, los cuales tienen una opinión propia de sus aspectos culturales, mirada desde dentro.

${ }^{16}$ Perspectiva desde el punto de vista externo de una cultura estudiada, que es mirada desde afuera. Cabe señalar que estos conceptos son términos originales del lingüista Kenneth Pike, quien los utilizó para distinguir la fonología de la fonética, no obstante estoy utilizando también la perspectiva antropológica de Marvin Harris. Para un seguimiento teórico e histórico de estos términos usados por ambos autores, véase Á. Díaz de Rada, op. cit., pp.62-79. 
simbólicas, mi perspectiva como practicante (emic) me permite obtener un entendimiento completo de ellas, ya que : "La socialización de una nueva religión conlleva también aprender los nuevos términos y sus significados, los cuales sólo pueden ser cabalmente entendidos por los adeptos." ${ }^{17}$ Por otro lado, este estudio lo realicé desde una perspectiva científica (etic), específicamente como lingüista, todos los conceptos y las teorías lingüísticas, etnológicas y antropológicas me otorgan la objetividad necesaria para poder analizar este fenómeno de uso del lenguaje. Con la síntesis de estos dos frentes, el análisis se complementa de manera correcta, sin prejuicios, juicios de valor o conclusiones apresuradas, mostrando los detalles de esta interesante problemática. Al final de cuentas hay que reconocer que: "Eticlemic tiene la utilidad de permitirnos distinguir con la mayor precisión posible el plano de nuestras acciones, reflexiones e interpretaciones como investigadores del plano de las acciones, reflexiones e interpretaciones de las personas cuyo comportamiento tomamos por objeto de análisis." 18

En suma, puedo decir que estoy interesada en estudiar las prácticas sociales de los cristianos, configuradas en su discurso religioso, cuyas implicaciones sociales son múltiples. Por un lado, puedo observar la dinámica entre un lenguaje estándar y el lenguaje de los cristianos; por otro lado, puedo observar cómo se va replicando el uso de elementos religiosos en el contexto social de los cristianos y también fuera de él. Así, un análisis lingüístico de la Biblia resulta de sumo interés, en tanto es capaz de ejemplificar el funcionamiento de un grupo social y su lógica bajo su propio contexto.

\footnotetext{
${ }^{17}$ Carlos Garma Navarro, Buscando el espíritu. Pentecostalismo en Iztapalapa y la ciudad de México, México, Universidad Autónoma Metropolitana. Unidad Iztapalapa/Plaza y Valdés Editores, 2004, p. 229.

${ }_{18}$ Á. Díaz de Rada, op. cit., p. 75.
} 
La relevancia de este trabajo está dada por el hecho de que es un área poco explorada por los lingüistas, pues los pocos estudios sobre discursos religiosos se enfocan en el aspecto teológico de la doctrina cristiana y no en su contexto social y mucho menos en su lenguaje. Por lo anterior, puedo decir que un análisis del discurso de los cristianos, resulta de suma importancia para analizar el funcionamiento del lenguaje religioso. La transportación del texto religioso por parte del creyente a las diferentes esferas sociales de su vida cotidiana es lo que caracteriza y hace muy interesante este fenómeno lingüístico. Este salto le otorga a mi investigación un carácter innovador que trataré de explotar en cada página.

La organización de la investigación es la siguiente. El primer capítulo está dedicado a exponer el contexto histórico del cristianismo, así como una reflexión acerca de la diversidad del mismo, con el fin de acercar al lector a la comprensión de mi objeto de estudio. El segundo capítulo está dedicado a la discusión crítica y analítica de los conceptos que me ayudaron a construir mi análisis del discurso, por ejemplo, enunciado, escena enunciativa, género discursivo, entre otros. Al introducir un concepto nuevo trataré de adecuarlo al contexto de mi investigación para poder aplicarlo de una mejor manera. El tercer capítulo contiene el análisis que realicé de mi corpus, mi punto de partida es un breve seguimiento de las prácticas cristianas de socialización de su fe que van más allá de la Biblia, por ejemplo, la imágenes en la catacumbas romanas en los inicios del cristianismo y la conformación de símbolos de identidad como el pez que sigue siendo utilizado en comercios, automóviles, entre otros soportes; posteriormente me dedico al análisis de las pintas en la calle, los Tratados Chick y las alabanzas. Cierro la investigación presentando las conclusiones, donde además de su carácter reflexivo, intento señalar caminos posibles para futuras investigaciones. 


\section{Breve planteamiento histórico-conceptual}

El presente capítulo tiene el objetivo de presentar un breve seguimiento histórico del cristianismo, identificando sus vínculos con el judaísmo y el protestantismo. Mi punto de partida son las acciones de los primeros cristianos incluidos los discípulos de Jesús, pasando por la persecución del Imperio romano, la Reforma protestante hasta llegar a la situación actual del cristianismo en México. Se trata de un esfuerzo por entender el presente de esta religión en nuestro país, además el seguimiento histórico ayuda a comprender la resistencia por parte de los creyentes a ser confundidos como pertenecientes a otras religiones como el catolicismo.

La segunda parte del capítulo está dedicada a discutir las diversas denominaciones presentes en el cristianismo, mi objetivo es justificar mi postura, que explora el camino de hablar en esta investigación de un cristianismo en general. Cabe señalar que mi decisión no responde a un parámetro reduccionista, simplemente corresponde a las necesidades analíticas actuales de mi investigación, pienso que posteriormente podría enfocarme detalladamente a cada una de las variantes del cristianismo. Además incluyo una breve descripción de la forma en que se encuentran constituidas algunas denominaciones cristianas, destacando que es posible encontrar múltiples modelos organizativos, esto resulta un diferenciador con respecto a otras religiones, en donde la jerarquía marca un rígido modelo vertical.

En suma el capítulo orienta al lector sobre las características principales de mi objeto de estudio, pienso que estas acotaciones son necesarias para entender la lógica de las prácticas que quiero analizar, como son el caso de las pintas en la calle, los Tratados Chick y las alabanzas. 


\section{1 ¿Qué es el cristianismo? Un seguimiento histórico}

Al iniciar mi investigación, uno de los primeros problemas que tuve que resolver fue la definición del cristianismo, esto para diferenciarlo de otras tradiciones culturales, en especial el catolicismo. Para resolver este inconveniente decidí enfocarme en el desarrollo histórico para entender la actitud de los cristianos al momento de sustentar su identidad. Considero pertinente retomar los hechos históricos fundamentales para entender esta situación.

Indagando en el pasado, se puede afirmar que formalmente, los cristianos existieron desde el momento en que Jesús contó con sus primeros seguidores, etimológicamente el término "cristiano" fue utilizado por primera vez alrededor del año 60 d. C. en Antioquía: "Y se congregaron allí todo un año con la iglesia, y enseñaron a mucha gente; y a los discípulos se les llamó cristianos por primera vez en Antioquía." ${ }^{19}$ Sin embargo, la manera de vivir de los cristianos se fue definiendo durante los años que estuvo el ministerio ${ }^{20}$ de Jesús, quien a su vez conocía perfectamente las tradiciones y costumbres de los judíos, puesto que él mismo era judío, por lo cual contaba con una formación sólida dentro de esta cultura. Lo anterior, provocó que algunas de las enseñanzas adquiridas en su vida, las heredara a sus propios discípulos. Por lo anterior, se puede afirmar que el cristianismo tiene sus raíces en la tradición judía, lo que nos da el fundamento para situar el origen de los preceptos cristianos en el año 4,000 a. C. relacionado con lo vivido por Abraham, quien es considerado el padre de la fe. ${ }^{21}$

\footnotetext{
${ }^{19}$ Hechos 11:26.

${ }^{20}$ Lapso de tiempo en el que Jesús predicó y realizó, según el cristianismo, sus milagros, aproximadamente esto duró tres años y medio.

${ }^{21}$ Hay que recordar que Abraham, personaje bíblico, estuvo a punto de sacrificar a su primogénito en obediencia a Dios, demostrando la gran fe que tenía, por lo que Dios decidió salvar al hijo de Abraham.
} 
Continuando el seguimiento cronológico, se puede identificar el paleo-cristianismo, que va del año 30 al año 325 d. C. En estos primeros años es cuando, en la práctica, los cristianos fueron adaptándose a la difícil situación que enfrentaron durante el dominio romano. Uno de los primeros objetivos de los cristianos era propagar el evangelio legado por Jesús, mismo que provocó a las autoridades romanas a que los persiguieran. El principal problema era que los seguidores de Jesús no estaban dispuestos a seguir con la tradición de rendirle culto al emperador, lo que los romanos consideraban contrario a la pax de ourum $^{22}$ una situación que ponía en peligro la sobrevivencia del Imperio. Este hecho no era un asunto menor, pues para obtener la defensa de esta paz, el Imperio era capaz de movilizar ejércitos para restablecerla; el antecedente directo fue la guerra contra los judíos, ésta se desencadenó entre los años 66-73 d. C., dando como resultado final la expulsión de los judíos del Imperio Romano y la destrucción del templo de Herodes. “Jerusalén estaba en ruinas, el templo había ardido. De la resistencia judía no quedaba ya más que unos grupos insignificantes, ocultos en cuevas, que sucumbirían al cabo de tres años. Judea convirtióse en una provincia romana, separada de Siria y ocupada por una legión en Jerusalén." ${ }^{23}$ La principal causa de esta guerra fue la negativa de los judíos de reconocer la divinidad del emperador.

Durante los años del paleo-cristianismo, el Imperio Romano vivió lo que se conoce como " La crisis del siglo III", que comprende los años 235 a 284 d.C. En esta etapa, se empezaron a tener serias dificultades defensivas, en vista de que, la mayoría del ejército imperial se fue llenando de extranjeros, los cuales luchaban sólo por el botín obtenido de la guerra y no por exaltar la gloria romana. En materia política, los golpes de estado fueron

\footnotetext{
${ }^{22}$ La paz de los dioses, implicaba no crear hostilidad entre ellos, se les ofrecían ofrendas a todos los dioses conocidos con el objetivo de no contrariar a ninguno de ellos y evitar así, repercusiones adversas en contra de los objetivos del Imperio.

${ }^{23}$ Flavio Josefo, La guerra de los judíos, México, Porrúa, 2008, p. xii.
} 
sucediendo uno tras otro e incluso se llegó a tener más de un emperador a la vez: “Los incidentes de este período son difíciles de seguir, pero están dominados por dos hechos sobresalientes: primero, las invasiones bárbaras sobre la frontera reno-danubiana y el peligro persa; segundo, las continuas conmociones militares, junto con numerosas usurpaciones que llevan al trono a personajes indignos." 24

Todo lo anterior, propició un ambiente de pesimismo generalizado en la población romana, la religión politeísta romana no daba esperanza a sus seguidores dado que se enseñaba que no había vida después de la muerte. El común de la población se sentía abatido, ya que la vida representaba incertidumbre cotidiana. Bajo este escenario, las enseñanzas cristianas van a florecer en la sociedad romana, debido a que el mensaje dado por los cristianos ofrece recompensas después de la muerte: "Jesús les respondió: Os lo he dicho, y no creéis; las obras que yo hago en nombre de mi Padre, ellas dan testimonio de mí; pero vosotros no creéis, porque no sois mis ovejas, como os he dicho. Mis ovejas oyen mi voz, y yo las conozco, y me siguen, y yo les doy vida eterna; y no perecerán jamás, ni nadie las arrebatará de mi mano." ${ }^{25}$ Esto le resultará muy atractivo a la población romana, por lo tanto muchos de ellos adoptaron al cristianismo como religión.

La gran popularidad del cristianismo se convirtió en una amenaza para el Imperio, sobre todo para la figura del emperador pues no se reconocía su carácter divino. A pesar de las persecuciones que vivían los cristianos, los emperadores no pudieron detener el

\footnotetext{
${ }^{24}$ Armind Lozano y Emilio Mitre, Análisis y comentarios de textos-históricos I. Edad Antigua y Media, Madrid, Alhambra, 1984, pp. 95-96.

${ }^{25}$ Juan 10: 25-28. Esta promesa aparece reiteradamente en el Nuevo Testamento, por ejemplo en Marcos 10:2930: "Respondió Jesús y dijo: De cierto os digo que no hay ninguno que haya dejado casa, o hermanos, o hermanas, o padre, o madre, o mujer, o hijos, o tierras, por causa de mí y del evangelio, que no reciba cien veces más ahora en este tiempo; casas, hermanos, hermanas, madres, hijos, y tierras, con persecuciones; y en el siglo venidero la vida eterna."
} 
crecimiento de éstos: "La unidad religiosa en torno a los dioses del panteón romano y del culto imperial fue considerada un elemento fundamental de esta política y el cristianismo, [sic] que había alcanzado una gran difusión en el medio siglo anterior, representaba, a los ojos de los elementos más tradicionalistas, un obstáculo fundamental para alcanzar" ${ }^{26}$ la cohesión del Imperio. La lógica imperial sostenía que al ejercer represión contra ellos, los cristianos abandonarían su fe, sin embargo las autoridades nunca entendieron que para un seguidor de Cristo, morir por la palabra de Dios garantiza su entrada al cielo: "A cualquiera, pues, que me confiese delante de los hombres, yo también le confesaré delante de mi Padre que está en los cielos. Y cualquiera que me niegue delante de los hombres, yo también le negaré delante de mi Padre que está en los cielos. ${ }^{27}$ Ellos morían convencidos de que habían obtenido la salvación eterna y por ello no renunciaron a su fe.

A causa de lo anterior, en el año 313 d. C., fue emitido el Edicto de Milán por orden de Constantino I El Grande, en el cual se otorgaba la libertad religiosa dentro de la jurisdicción romana: “[...] que a nadie se [sic] le sea negada la facultad de seguir libremente la religión que ha escogido para su espíritu, sea la cristiana o cualquier otra que crea más conveniente [...]"28 El objetivo de este texto fue lograr la armonía dentro del Imperio, lo cual era una prioridad para Constantino, puesto que él fue el encargado de reformar profundamente el Imperio Romano para poder superar "la crisis del siglo III".

Posteriormente, en el año 380 d. C., el emperador romano Teodosio decretó el Edicto de Tesalónica, en donde es proclamado el catolicismo y no el cristianismo, como religión

\footnotetext{
${ }^{26}$ Manuel Sotomayor y José Fernández Ubiña (coords.), Historia del cristianismo I. El mundo antiguo, Madrid, Trotta, 2003, p. 307.

${ }^{27}$ Mateo 10:32-33.

28 "Edicto de Milán“, en Miguel Artola, Textos fundamentales para la historia, Madrid, Alianza, 1978, p.21.
} 
oficial del Imperio. Para entender mejor esta situación es necesario incluir el edicto en su totalidad:

Queremos que todas las gentes que estén sometidas a nuestra clemencia sigan la religión que el divino apóstol Pedro predicó a los romanos y que, perpetuada hasta nuestros días, es el más fiel testigo de las predicaciones del apóstol, religión que siguen también el papa Dámaso y Pedro, obispo de Alejandría, varón de insigne santidad, de tal modo que según las enseñanzas de los apóstoles y las contenidas en el Evangelio, creamos en la Trinidad del Padre, Hijo y Espíritu Santo, un solo Dios y tres personas con un mismo poder y majestad. Ordenarnos que de acuerdo con esta ley todas las gentes abracen el nombre de cristianos y católicos, declarando que los dementes e insensatos que sostienen la herejía y cuyas reuniones no reciben el nombre de iglesias, han de ser castigados primero por la justicia divina y después por la pena que lleva inherente el incumplimiento de nuestro mandato, mandato que proviene de la voluntad de Dios. ${ }^{29}$

El primer elemento que nos ayuda a reconocer que dentro del edicto se está hablando del catolicismo y no del cristianismo es la figura del papa: “[...] religión que siguen también el papa Dámaso y Pedro, obispo de Alejandría, varón de insigne santidad [...]"30 Dentro de la Biblia, nunca es mencionado el papa, ni como autoridad, ni como puesto de jerarquía, simplemente esta palabra no aparece en ésta, del mismo modo, los primeros cristianos nunca mencionan que le hayan otorgado a alguien esa designación.

Otro fragmento del Edicto que nos ayuda a identificar las diferencias entre católicos y cristianos, es el siguiente: “Ordenarnos que de acuerdo con esta ley todas las gentes abracen el nombre de cristianos y católicos, declarando que los dementes e insensatos que sostienen la herejía y cuyas reuniones no reciben el nombre de iglesias [...]"31 Es claro que en el edicto se reconoce la distinción entre cristianos y católicos, el simple hecho de mencionar dos términos que supuestamente designan a un mismo grupo, nos habla de que existen diferencias, si católicos y cristianos fueran lo mismo ¿por qué utilizar dos términos? Lo que

\footnotetext{
29 "Edicto de Tesalónica“, en Miguel Artola, op.cit., pp.22-23.

${ }^{30}$ Ídem.

${ }^{31}$ Ídem.
} 
podemos discernir es que el edicto trata de erradicar esa diferencia apropiándose del término cristiano, equiparándolo con el de católico. Del mismo modo, dentro del Edicto se reconoce y se desprestigia a otro grupo, al cual se le llama hereje y cuyas reuniones no se les reconoce como iglesia.

Por otro lado, en este contexto, la figura del papa de la iglesia de Roma se convirtió en la cabeza de la Iglesia católica, la cual va obteniendo más poder y se va transformando en el símbolo de la tradición en la antigüedad, durante toda la época medieval. En Occidente, durante todo el medievo, la Iglesia católica fue la autoridad máxima representada por la figura del papa, el cual bendecía o condenaba cualquier situación, ya fuera en la esfera política, militar, económica o personal. Bajo esta situación, los cristianos no tenían ninguna posibilidad de competir frente a esta institución:

En el contexto general de la configuración de Occidente como una sociedad represora, el mundo feudal fue construyéndose sobre el principio de ordenar y excluir a los disidentes herejes, judíos, leprosos, sodomitas-. El progresivo endurecimiento de las medidas represivas se vio favorecido desde el siglo XII por la consolidación del proceso de centralización eclesiástica (derecho canónico, monopolio pontificio de la ortodoxia, protagonismo de las órdenes monásticas, desarrollo de las estructuras eclesiales) y por el fortalecimiento interno de las monarquías feudales (Francia, Inglaterra, Corona de Aragón, Castilla). Pero el camino que condujo a la represión militar - la cruzada- o a la represión policial y judicial -la Inquisición- no habría sido posible sin la construcción de un potente discurso eclesiástico: los herejes como un cáncer que debía ser erradicado de la sociedad cristiana; la herejía como un todo homogéneo y uniforme que aspiraba a la destrucción de la cristiandad. ${ }^{32}$

Bajo estas circunstancias, paradójicamente los cristianos encontraron un refugio en los territorios dominados por los musulmanes, debido a su característica tolerancia hacia lo que ellos denominan "los pueblos del libro" (judíos y cristianos). Éstos tenían la opción de convertirse en musulmanes o seguir con su fe. Si querían seguir con su fe tenían que pagar un impuesto al Estado, sin sufrir mayores cambios en su vida diaria. Principalmente, en los

\footnotetext{
${ }^{32}$ Emilio Mitre Fernández (coord.), Historia del cristianismo II. El mundo medieval, Madrid, Trotta, 2006, p. 388.
} 
territorios de Asia, África y Medio Oriente dominados por el Islam, es donde se van a refugiar los cristianos de la intolerancia de Occidente: "El Islam era una religión tolerante con las otras dos del Libro Revelado -judaísmo y cristianismo- a las que tanto debía pero a las que dejaba en un plano de franca subordinación."33

En Occidente, específicamente en los reinos germánicos, no se encontrarán noticias de los cristianos prácticamente hasta la Reforma de 1517 de Martín Lutero y el nacimiento del protestantismo; un movimiento que nace en el seno de la Iglesia Católica y que trata de reivindicar las primeras enseñanzas de Cristo. Lutero cuestionó las actitudes de la Iglesia como las ventas del perdón e indulgencias, la prohibición de leer la Biblia, dar las misas en latín, entre otros. "La alternativa propuesta por Lutero implicaba, cómo no, cambios profundos en esta religiosidad, que, hay que insistir en ello, en muchas de sus expresiones no era sólo popular. Su alternativa se centró en ofrecer, en vez de tantas mediaciones y para él supersticiones, la única que valía la pena para asegurar la salvación: sólo Cristo. Pero Cristo descubierto en la sagrada Escritura y sólo en ella, fuente única de fe."34

Muchos desacuerdos hacen inconciliables al protestantismo con el catolicismo, como lo señaló Martín Lutero, en su obra Cuestionamiento al Poder y Eficacia de las Indulgencias, donde denuncia las incongruencias de los católicos con respecto a la Biblia: “Cualquier cristiano verdadero, sea que esté vivo o muerto, tiene participación en todos los bienes de Cristo y de la Iglesia; esta participación le ha sido concedida por Dios aun sin cartas de indulgencias." ${ }^{35}$ De manera general, se puede decir que Lutero estaba inconforme con las

\footnotetext{
${ }^{33}$ Ibíd., p.37.

34 Antonio Luis Cortés Peña (coord.), Historia del cristianismo III. El mundo moderno, Madrid, Trotta, 2006, p. 93.

35 Martín Lutero, Las 95 tesis, disponible en http://www.fiet.com.ar/articulo/95_tesis.pdf (consultado el 15 de febrero de 2018).
} 
actitudes de algunos clérigos dentro de la iglesia, ya que consideraba que las enseñanzas de estos se alejaban e incluso contradecían el mensaje bíblico. Este personaje estaba plenamente convencido de que el hombre no podía revocar, ni contradecir lo que Dios había dicho, pues la autoridad máxima le pertenece a Dios y no al hombre. Si para lograr la salvación, una persona debía sufrir, las autoridades eclesiásticas no podían evitar ese sufrimiento por más indulgencias y bendiciones que emitieran, esto es claro en la conclusión de sus 95 tesis:

Que se vayan, pues todos aquellos profetas que dicen al pueblo de Cristo: "Paz, paz"; y no hay paz. Que prosperen todos aquellos profetas que dicen al pueblo: "Cruz, cruz" y no hay cruz. Es menester exhortar a los cristianos que se esfuercen por seguir a Cristo, su cabeza, a través de penas, muertes e infierno. Y a confiar en que entrarán al cielo a través de muchas tribulaciones, antes que por la ilusoria seguridad de paz. ${ }^{36}$

Bajo este nuevo movimiento, las ideas cristianas tienen un nuevo espacio en Occidente sin dejar de lado su lugar en Asia y África; por otra parte, la Iglesia Católica reaccionó con la Contrarreforma encabezada por los jesuitas, quienes van a reivindicar el papel del catolicismo como la verdadera guardiana del mensaje de Dios y la única y verdadera religión. La disputa va a tener distintos resultados dependiendo del país donde centremos nuestra atención, por ejemplo, España se convierte en la defensora del catolicismo al igual que Francia e Italia, sin embargo en países como Holanda e Inglaterra, el protestantismo tendrá buena aceptación.

Aproximadamente, en el año de 1605 las primeras colonias inglesas y holandesas se empezaron a establecer en el norte del continente americano, desde el ámbito religioso, la mayoría de los colonos eran protestantes. Una vez alcanzada la independencia de la corona inglesa por parte de las llamadas 13 colonias, Estados Unidos no deja de crecer y fortalecerse

36 Ídem. 
en todos los sentidos hasta convertirse en la primera potencia mundial. El ambiente favorable que se vivía posibilitó la existencia de misiones ${ }^{37}$ enviadas a distintas partes del mundo.

Específicamente, en México antes de la Guerra de Reforma (1857-1861), la religión católica era la oficial y no había libertad de cultos. Con la ley de libertad de cultos del 4 de diciembre de 1860, México abría las puertas al establecimiento de otras religiones. El texto ordenaba lo siguiente:

Artículo 1. Las leyes protegen el ejercicio del culto católico y de los demás que se establezcan en el país, como la expresión y efecto de la libertad religiosa, que siendo un derecho natural del hombre, no tiene ni puede tener más límites que el derecho de tercero, y las exigencias del orden público. En todo lo demás, la independencia entre el Estado por una parte, y las creencias y prácticas religiosas por otra, es y será perfecta e inviolable. Para la aplicación de estos principios se observará lo que por las leyes de la Reforma y por la presente se declara y determina. ${ }^{38}$

De esta manera: "Los presbiterianos llegaron al norte de México al año siguiente, en 1857, estableciendo iglesias en las ciudades de Zacatecas y Monterrey. Los bautistas llegaron en 1862 y los metodistas en 1872, también fundaron iglesias en la mitad norte del país."39 Estos grupos fueron recibidos como una minoría exótica, eran mal vistos, se les consideraba como herejes sectarios por estar en contra de la iglesia católica; hay que recordar que esta institución formó parte fundamental en el nacimiento y establecimiento de México como Nación independiente: "Por su parte, la iglesia católica hace frente a la invasión de las sectas, tratando de desacreditarlas bajo la sospecha de que la penetración de estos grupos religiosos

\footnotetext{
${ }^{37}$ Las misiones se encuentran conformadas por personas que viajan por distintas partes del mundo con el objetivo de evangelizar a una o varias personas al cristianismo, socializando la fe.

38 "Ley sobre libertad de cultos 4 de diciembre de 1860", Disponible en http://www.anfade.org.mx/docs/ponencias/Leysobrelibertadcultos_Anexo13.pdf (consultado el 20 enero de 2018).

${ }^{39}$ Carlos Garma Navarro y Virginia Garrard Burheh, "Protestantism in Mexico", en John Bowden (ed.), Encyclopedia of Christianity, Nueva York, Oxford Univesity Press, 2006, p. 1. "Presbyterians arrived in Northern Mexico the following year, in 1857, establishing churches in the cities of Zacatecas and Monterrey. Baptists arrived in 1862 and Methodists in 1872, also founding churches in the northern half of the country." [la traducción es mía].
} 
obedece a fines políticos vinculados con los intereses del imperialismo norteamericano en México." 40

Para comprender la hostilidad que vivieron los primeros protestantes en México, hay que tener en cuenta que el catolicismo se encuentra fuertemente arraigado en nuestro país, como consecuencia de la conquista española. A partir de ese momento, se vivió un proceso de sincretismo entre las costumbres de los mesoamericanos y el catolicismo español.Un claro ejemplo de ello fue lo sucedido con Tonantzin, “ la madre de los dioses", una figura que fue aprovechada para arraigar el culto a la virgen de Guadalupe, como símbolo de la nueva realidad que representaba la Nueva España. No era fácil abrirse a nuevas religiones en un país mayoritariamente católico.

Una de las razones por las cuales el gobierno mexicano buscaba la entrada de migrantes protestantes era su deseo de modernizar el país, por un lado la migración se veía como una estrategia para incentivar las inversiones dentro del país. "Durante todo el siglo XIX, México intentó atraer migrantes y a los posibles colonos con la promulgación de leyes." ${ }^{41}$ Por otro lado, siempre se reconoció la admiración de los liberales por el progreso de Estados Unidos de América y las virtudes del estilo de vida protestante, por ejemplo, la llamada ética de trabajo: "Los primeros misioneros, por ejemplo, buscaron establecer en México un estilo de vida ético basado en la prohibición del alcohol, el apoyo a la monogamia, haciendo hincapié en la educación y valorizando los méritos del trabajo duro."42

40 Juan Schuster, “Antecedentes históricos de la penetración protestante en México", Disponible en http://cdigital.uv.mx/bitstream/123456789/2263/2/198658P12.pdf ( consultado el 20 de enero 2018).

41 Marcela Martínez Rodríguez, "El proyecto colonizador de México a finales del siglo XIX. Algunas perspectivas comparativas en Latinoamérica", en Secuencia, núm. 76, enero/abril 2010, p. 110.

${ }^{42}$ Carlos Garma Navarro, op. cit. 2006, p. 2, "The first missionaries, for example, sought to establish in Mexico an ethical way of life based on the prohibition of alcohol, support for monogamy, by placing an emphasis on education and valorizing the merits of hard work." [la traducción es mía]. 
En lo que respecta al siglo XX, el país comenzó la centuria con una revolución que cambiaría por completo al gobierno mexicano y a sus habitantes. Por su parte el protestantismo, no se vería afectado debido a la promulgación de la Constitución de 1917, la cual ratificaba la libertad de culto dentro del territorio mexicano, lo anterior no implicaba que la religión católica disminuyera su influencia en el común de la población. Dentro de las tensiones entre el Estado mexicano y la religión, se puede mencionar la llamada Guerra cristera que transcurrió entre 1926 y 1929, un conflicto que tuvo lugar durante el gobierno de Plutarco Elías Calles: "la iglesia quedó bajo la tutela del gobierno y excluida de las nuevas empresas públicas del Estado, ya que el plan que los nuevos gobernantes tenían para el nuevo país emergente consideraba impropia la injerencia de dicha institución en los asuntos políticos del país." ${ }^{43}$

En el caso del protestantismo podemos señalar que, aunque las tendencias hacia un Estado laico siguieron avanzando durante el siglo XX, existió una colaboración muy particular entre el presidente Lázaro Cárdenas y organizaciones protestantes que buscaban aportar algo a la sociedad mexicana además de su oferta religiosa, así es como se explica la llegada al país, en el año de 1935, del Instituto Lingüístico de Verano: “el presidente apoyó al SIL para su trabajo entre los indígenas, particularmente en la transcripción y traducción de lenguas indígenas, y solicitó que SIL (Summer Institute Linguistics) iniciara un proyecto para traducir la Biblia a cada idioma indígena en el país. ${ }^{24}$ Un elemento común que se puede

\footnotetext{
${ }^{43}$ Claudia Julieta Quezada, "La mujer cristera en Michoacán, 1926-1929”, en Historia y Memoria, núm. 4, 2012, p. 195.

${ }^{44}$ Carlos Garma Navarro, op. cit., 2006, p. 4, "the president supported SIL for its work among the indigenous, particularly in transcribing and translating indigenous languages, and he requested that SIL initiate project to translate the Bible into every indigenous language in the country." [la traducción es mía].
} 
observar desde el siglo XIX es la tolerancia del protestantismo por parte del gobierno mexicano que reconoce el trabajo a favor de la sociedad que hacen los protestantes. ${ }^{45}$

De manera general, el protestantismo, que en nuestro país también es reconocido como cristianismo, se mantuvo durante los siguientes años como una religión minoritaria. Carlos Garma ${ }^{46}$ reconoce un crecimiento muy grande en la década de los 70 del siglo XX, una tendencia a la alza que se mantiene, hasta ahora, según este autor. Dentro de las variantes cristianas nos dice que: "el pentecostalismo se ha convertido en la principal expresión del protestantismo en México, con una membresía más orientada a las clases populares de la sociedad mexicana, y ayudado por la formación de líderes religiosos mexicanos, incluyendo pastores indígenas, que entienden sus culturas nativas y las necesidades de su gente. ${ }^{47}$ Esto nos demuestra que México no sólo es receptor pasivo de esta religión, sino que se apropia de las enseñanzas religiosas adaptándolas a su entorno, lo cual permite un acercamiento más fácil de los nuevos adeptos, que no lo reconocen como algo ajeno a su entorno.

Un gran cambio para la vida política y religiosa del país tuvo lugar durante el sexenio del presidente Carlos Salinas de Gortari, específicamente en el año de 1992, donde la Constitución fue reformada dando lugar a la Ley de Asociaciones Religiosas, que implica el reconocimiento legal de las Asociaciones Religiosas, el derecho a votar a los líderes religiosos ${ }^{48}$ y el permiso para celebrar ceremonias religiosas fuera de los templos, así como manifestaciones públicas de fe. Los cambios provocaron el restablecimiento de las relaciones

\footnotetext{
${ }^{45}$ El apoyo de los presidentes mexicanos hacia el SIL se perdió a partir de 1979 debido a presiones políticas.

${ }^{46}$ Carlos Garma Navarro, op. cit., 2006, p. 5.

${ }^{47}$ Ídem. "Pentecostalism has became the main expression of Protestantism in Mexico, with a membership more oriented to the popular classes of Mexican society, and aided by the formation of Mexican religious leaders, Including indigenous pastors, who understand their native cultures and the needs of their people." [la traducción es mía].

${ }^{48}$ Pueden aspirar a un cargo de elección pública siempre y cuando hayan renunciado a su puesto religioso 5 años antes del proceso electoral.
} 
diplomáticas entre México y el Vaticano, por lo que la Iglesia Católica se vio beneficiada, en este sentido los cristianos no cambiaron sustancialmente su papel como minoría religiosa.

En 2010, se legisló nuevamente sobre los derechos constitucionales de las Asociaciones Religiosas, pero el resultado no afectó las libertades ya existentes: "las libertades éticas, la prohibición de que las reuniones de cultos sean utilizadas con fines políticos, mantener la restricción al Congreso de legislar en contra de religión alguna y que los actos de culto público se celebren en los templos fueron definidos a partir del trabajo parlamentario de algunos diputados de partidos de izquierda. Esos contenidos garantizan la laicidad del Estado." 49

Por último vale la pena atender a la situación actual del Partido Encuentro Social (PES), el cual desde su fundación como partido estatal en 2006 y posteriormente, como partido nacional en 2014 , ha sido señalado como un partido religioso, ${ }^{50}$ sin embargo, hasta el momento ha logrado permanecer vigente, incluso en las elecciones presidenciales de 2018, donde figuró en la coalición de candidato Andrés Manuel López Obrador. Es interesante resaltar la ceremonia de postulación del candidato por parte del PES que tuvo lugar el día 20 de febrero del 2018, en la que el dirigente del partido político, Hugo Éric Flores, hizo una analogía entre Andrés Manuel López Obrador y el personaje bíblico Caleb. Esto en referencia

\footnotetext{
${ }^{49}$ Iván García Garate, "Los contenidos sustanciales de la libertad de religión se definen por la Constitución y por tratados internacionales de derechos humanos interpretados por los órganos jurisdiccionales competentes. No por la Iglesia", en Letras Libres, 21 de marzo de 2012, disponible en http://www.letraslibres.com/mexicoespana/religion-y-constitucionalismo-mexicano (consultado el 15 de junio de 2018).

${ }^{50} \mathrm{Su}$ fundador Hugo Éric Flores Cervantes, reconoce que existen militantes cristianos pero menciona que son minoría en el partido. Véase, Pedro Domínguez, "No somos un partido religioso", en Milenio, 10 de febrero de 2014, disponible en http://www.milenio.com/politica/partido-religioso-contrario-liberales-dirigente-encuentrosocial (consultado el 15 de junio de 2018).
} 
a la conquista de la tierra prometida que alcanzó el israelita, a pesar de todos los obstáculos que se presentaban.

Durante la ceremonia Hugo Éric Flores le dedicó al candidato la canción “Dame este monte" ${ }^{\natural 1}$ del cantautor cristiano Jesús Adrián Romero, mostrando un video con imágenes de la carrera política del político tabasqueño. "Esa es la canción que le queremos poner don Andrés Manuel López Obrador, surge de que pensamos que usted es Caleb y que está a punto de conquistar el monte Hebrón, donde gobernó David."52 Paradójicamente, a pesar del triunfo de la coalición de los partidos políticos, Movimiento de Regeneración Nacional (MORENA), Partido del Trabajo (PT) y Partido Encuentro Social (PES), éste último sigue en espera de la resolución final del Tribunal Electoral del Poder Judicial de la Federación, para saber si su registro como partido político a nivel nacional seguirá vigente.

Considerando todo lo anterior, es evidente que, un factor común, presente durante toda la historia del cristianismo, es su capacidad de adaptación ante el contexto vivido. Desde los años del ministerio de Jesús hasta su llegada a México ha tenido el papel de una religión minoritaria. Específicamente, en México, su posición frente a la amplia mayoría católica ha determinado sus acciones $y$, en cierto sentido, ha fortalecido la identidad de aquellos que se sienten diferentes a la mayoría, por pertenecer al cristianismo, haciendo de su religión un factor diferenciador en su vida.

\footnotetext{
${ }^{51}$ En la canción se resalta la vida de constante lucha que llevó Caleb, conquistando y peleando contra los enemigos de Israel, hasta alcanzar la conquista de Canaán, la cual es la tierra que Dios prometió a los israelitas cuando salieron del dominio de esclavitud de los egipcios.

52 Tomado de José Antonio Belmont, "AMLO, a punto de conquistar la tierra prometida: Hugo Éric Flores" en Milenio, disponible en http://www.milenio.com/politica/amlo-punto-conquistar-tierra-prometida-hugoeric-flores (consultado el 30 de agosto de 2018).
} 
Todo este recuento histórico responde a la lógica de comprender el pasado del cristianismo, en cada una de las épocas en las que ha tenido lugar, su identidad se encuentra contrapuesta a las religiones dominantes de su contexto, es por ello que el creyente se siente identificado y diferenciado del catolicismo u otra religión. Desde la perspectiva de mi investigación debo decir que aunque el cristiano no conozca la historia del cristianismo a detalle, sí se diferencia y reconoce como parte de un grupo con características propias y diferente a otras creencias religiosas.

\subsection{Diversidad del cristianismo}

Dentro del cristianismo existen diferentes variantes, las cuales se han desarrollado y definido a lo largo del tiempo, entre ellas se encuentran la pentecostal, bautista, evangélica, metodista, entre otras. Cabe señalar que esta ha sido una de dificultades con las que me he encontrado al realizar mi investigación. Al momento de reconocer esta diversidad me vi en la necesidad de tomar la decisión de tener una perspectiva aglutinante, es decir, trascender las diferencias y enfocarme en los aspectos comunes, unificándolos en el término cristianismo. Concretamente en las prácticas que estudio (pintas en la calle, Tratados Chick, y alabanzas) las diferencias entre denominaciones no trasciende, debido a que todos aceptan y utilizan estos mecanismos para propagar el evangelio.

Sin duda, un análisis pormenorizado de las diferentes variantes junto con la identificación de las estrategias de propagación evangélica que ocupan sería muy esclarecedor, sin embargo, por el momento, está perspectiva la dejaré pendiente para futuras investigaciones. Para demostrar al lector las diferencias pero también las semejanzas dentro 
del cristianismo hablaré, brevemente, de tres de las variantes más representativas, la pentecostal, la bautista y la metodista. En cada caso menciono sus características principales y destaco su organización, con el fin de identificar de una mejor manera al enunciador ${ }^{53}$ dentro de mi corpus. Posteriormente me ocupo de los elementos que hermanan estas denominaciones.

En primera instancia me quiero ocupar del pentecostalismo, que como se mencionó en el apartado anterior, es la denominación con más presencia en México: "El pentecostalismo es la rama del cristianismo que pone gran énfasis en la Tercera Persona de la Trinidad, el Espíritu Santo. Los creyentes son ‘bautizados en el Espíritu’, una experiencia que se expresa a través de experiencias milagrosas y somáticas tales como hablar en lenguas, sanar enfermedades y otras conductas extáticas." 54

Como podrá apreciar el lector, la creencia central del pentecostalismo son los dones que otorga el Espíritu Santo. El don de la sanación se entiende como la facultad que tiene un individuo para curar a través de la oración y la imposición de manos $^{55}$ a sus hermanos en la fe. ${ }^{56} \mathrm{El}$ don de hablar en lenguas se refiere a la capacidad, por parte del creyente, de pronunciar sílabas o palabras, en muchos casos inconexas, en una lengua irreconocible, también se le puede llamar: "glosolalia, es una forma de vocalización que muestra varios rasgos distintivos. En primer lugar, no es estrictamente una lengua. Quien posee el don de

\footnotetext{
${ }^{53}$ Este término lo explicaré detalladamente dentro del apartado siguiente, sin embargo, se puede entender, burdamente, como aquél que se apropia del lenguaje produciendo enunciados.

${ }^{54}$ Carlos Garma Navarro, op. cit., 2006, p. 4. "Pentecostalism is the branch of Christianity that places great emphasis on the Third Person of the Trinity, the Holy Spirit. Believers are "baptized in the Spirit," an experience that is expressed through miraculous and somatic experiences such as speaking in tongues, healing of illness, and other ecstatic behavior." [la traducción es mía].

${ }_{55}^{5}$ Acto en el que un cristiano toca a otro al momento de orar, se realiza principalmente en la sanación.

56 Entendido como otro cristiano, existe cierta resistencia a imponer manos en personas inconversas, principalmente por temor a un castigo divino que se puede materializar en la perdida de la salud por parte del sanador.
} 
lenguas no entiende lo que dice. Lo que él o ella emite no son palabras con un significado específico. ${ }^{57}$ Cabe señalar que este don se complementa con el de interpretación de lenguas, que puede tener el mismo creyente u otro diferente. Se considera que a través del don de lenguas Dios se comunica con los creyentes.

En cuanto a la organización de los pentecostales no existe un modelo único, ya que, existen iglesias que se mueven de manera más independientes que otras. Por ejemplo, Carlos Garma en su investigación sobre el pentecostalismo en Iztapalapa encontró dos modelos claros. El primero contempla iglesias pequeñas que mantenían su independencia con respecto a organizaciones nacionales e internacionales: "Eran iglesias pequeñas que se habían escindido de organizaciones religiosas más grandes... el liderazgo recaía sobre pastores o predicadores activos y enérgicos que evitaron subordinarse o volver a la asociación vinculada... por lo menos así podían seguir siendo independientes y alejadas de una centralización burocrática o hierocrática." ${ }^{58}$ El segundo modelo incluye iglesias más estructuradas en donde la jerarquía marcaba, de cierta manera, el día a día de la congregación. A continuación replico un cuadro mostrado en la investigación de Carlos Garma en donde se muestra este aspecto:

\footnotetext{
${ }^{57}$ Carlos Garma Navarro, "La socialización del don de lenguas y la sanación en el pentecostalismo mexicano", en Alteridades, núm. 10, 2000, p. 86.

${ }^{58}$ Carlos Garma Navarro, op. cit., 2004, p. 154.
} 


\begin{tabular}{|lll|}
\hline \multicolumn{3}{|c|}{ Jerarquía } \\
\hline 1) & Obispo \\
\hline 2) & Pastor \\
\hline 3) & Diácono \\
\hline 4) & Predicador \\
\hline 5) & Autoridad en Congregación o Director de \\
& Fraternidad \\
\hline 6) & Creyente, miembro de la congregación \\
\hline
\end{tabular}

Cuadro 1. Jerarquía de la Iglesia ${ }^{59}$

Para fines explicativos quiero señalar brevemente la función de cada uno de estos elementos. El obispo está encargado de supervisar a diferentes iglesias en un territorio establecido, nombra y traslada a los pastores según la conveniencia de la congregación. Los pastores son los líderes de su congregación, sus funciones están enfocadas al campo espiritual (predicando el evangelio) pero también al administrativo (supervisando finanzas, logística de eventos, entre otras cosas), velan por el bienestar de su congregación y el buen funcionamiento de ésta. ${ }^{60}$ El diácono tiene funciones múltiples, puede ser desde tesorero hasta acomodador en las conferencias, pues según la Biblia los diáconos deben ser: “... honestos, sin doblez, no dados a mucho vino, no codiciosos de ganancias deshonestas; que guarden el misterio de la fe con limpia conciencia. Y éstos también sean sometidos a prueba primero, y entonces ejerzan el diaconado, si son irreprensibles. ${ }^{" 61}$ El predicador se encarga de oficiar las conferencias, cabe señalar que es libre de preparar el mensaje que quiere compartir cada que se presenta. La autoridad o director de fraternidad se encarga de liderar

\footnotetext{
${ }^{59}$ Tomado de Ibíd., p. 160.

${ }^{60}$ Los congregantes pueden acercarse al pastor, esperando algún consejo o guía, ya sea en el ámbito espiritual o terrenal.

${ }^{61} 1$ ra Timoteo 3:8-10.
} 
los distintos subgrupos de la congregación, estas fraternidades se organizan de diversas maneras, por ejemplo, varones, mujeres, jóvenes solteros, abuelos, entre otros. Por último, el creyente, a pesar de no ostentar ningún cargo, es una pieza fundamental de la congregación debido a que su asistencia es vital para la existencia de la Iglesia.

Hay que señalar que aunque cada eslabón depende del otro, existen dos elementos que no permiten considerar esta jerarquía de una manera tan rígida y vertical como a simple vista parece; en primer lugar, porque cada creyente se encuentra constantemente evaluando su pertenencia a cierta congregación, por lo que es común que cuando no se siente bien representado o guiado por las autoridades, abandone el grupo. "Los fieles lo pueden abandonar por otra iglesia y otro líder en el momento que quieran y, además, lo hacen con frecuencia." ${ }^{62}$ En segunda instancia, el pastor también puede abandonar la congregación para formar una Iglesia independiente, lo cual nos lleva al primer modelo de organización mencionado anteriormente. Estos factores impiden imponer un patrón para el estudio de las iglesias pentecostales, ya que cada región presenta sus particularidades, lo cual nos habla de cierta libertad organizativa por sí misma.

Por su parte, la presencia de los bautistas en México se puede rastrear desde el año $1862,{ }^{63}$ sin duda como resultado a la Ley de libertad de cultos promulgada por el gobierno mexicano. Su cohesión como grupo se basa en los siguientes siete principios: ${ }^{64}$

\footnotetext{
${ }^{62}$ Carlos Garma Navarro, op. cit., p. 150.

${ }^{63}$ Cfr. Cristina Gutiérrez Zúñiga, "El protestantismo histórico", en Renée De la Torre y Cristina Gutiérrez Zuñiga (coords.), Atlas de la diversidad religiosa en México, México, CIESAS-El Colegio de Jalisco-El Colegio de la Frontera Norte-El Colegio de Michoacán-Universidad de Quintana Roo-Secretaría de GobernaciónCONACYT, 2007, pp. 50-60.

64 Tomado de Convención Nacional Bautista de México A.R, "Principios bíblicos" disponible en https://drive.google.com/file/d/0B7QqmoT3PPhsSVRHVVhfRGpLNFE/edit (consultado el 18 de junio de 2018).
} 


\section{1-. Cristológico \\ 2.- Bíblico \\ 3.- Eclesiástico \\ 4.- Sociológico \\ 5.- Espiritual \\ 6.- Político \\ 7.- Evangelístico}

Expondré brevemente cada uno de ellos para entender la cosmovisión bautista. El principio número uno se puede sintetizar señalando que creen que Jesucristo es el centro de sus creencias, la creencia en él es la llave para la salvación eterna. El segundo principio considera que el Antiguo Testamento tiene validez, por ser revelación divina, pero la lógica bautista le otorga un papel de mayor importancia al Nuevo Testamento por contener las bases de su modo de vida: “es la razón por la que nuestra fe y nuestro parámetro para vivir la vida cristiana se encuentra fundado mayormente en el Nuevo Testamento." ${ }^{\circ 5}$ El tercer principio sostiene que para ser miembro de una congregación se deba aceptar que Jesús es el salvador y cumplir con el bautizo como manifestación de la conversión. El cuarto principio tiene que ver con una autoridad horizontal que reparte privilegios y responsabilidades a todos los miembros de la congregación: “todos los miembros tienen la misma responsabilidad y los mismos privilegios, y asimismo, cada uno de los miembros tiene el derecho de dar su opinión y su voto en la toma de decisiones." 66

El principio Espiritual que rige a los bautistas manda respetar la libertad de decisión que tiene cada persona, cada uno es libre de acatar los mandatos bíblicos o de abrazar la fe que más le plazca, por lo que la decisión de ser bautista y seguir su modo de vida deber ser libre. El sexto principio manda obedecer a las autoridades gubernamentales, respetando la

\footnotetext{
${ }^{65}$ Ídem.
}

${ }^{66}$ Ídem. 
separación Iglesia-Estado porque cada una tiene una misión que cumplir. Por último, el séptimo principio estipula que cada creyente debe dar a conocer el evangelio, debe ser misionero, además cada iglesia debe fomentar la creación de nuevas iglesias para cumplir con la llamada Gran Comisión ${ }^{67}$ reflejada en la Biblia: "Y Jesús se acercó y les habló diciendo: Toda potestad me es dada en el cielo y en la tierra. Por tanto, id, y haced discípulos a todas las naciones, bautizándolos en el nombre del Padre, y del Hijo, y del Espíritu Santo; enseñándoles que guarden todas las cosas que os he mandado; y he aquí yo estoy con vosotros todos los días, hasta el fin del mundo. Amén." 68

En cuanto a la organización de las iglesias bautistas, éstas forman parte de redes que van desde zonas regionales, nacionales y mundiales. Cabe señalar que la organización es horizontal, es decir no hay una jerarquía que imponga sus estatutos o designe autoridades a las iglesias locales. En el caso de México existe la Convención Nacional Bautista de México, misma que a su vez pertenece a la Alianza Mundial Bautista. Se debe mencionar que para dar un número exacto de cuantas iglesias bautistas están registradas en la Convención Nacional es necesario consultar el directorio de iglesias, sin embargo, se necesita previa autorización, ${ }^{69}$ la cual en mi caso está en proceso, por lo que, por el momento no puedo dar un número exacto de iglesias afiliadas.

Las Iglesias locales cuentan con la autoridad del pastor como la más importante, pero es común encontrar grupos de enseñanza bíblica y también creyentes organizados para salir

\footnotetext{
${ }^{67}$ Predicar el evangelio por toda la tierra y bautizar a los creyentes.

${ }^{68}$ Mateo 28:18-20.

${ }^{69}$ Por medio de un registro por internet en la página oficial de la Convención Nacional Bautista: http://www.convencionbautista.mx/
} 
a predicar fuera de las iglesias. ${ }^{70}$ Una vez más, la libertad de cada iglesia hace difícil plantear un modelo único, válido para cada caso. A pesar de ello, es posible darnos cuenta de la organización local, regional, nacional y mundial de las iglesias bautistas.

Toca el turno de hablar de los metodistas, cuyas creencias se encuentran basadas en la Biblia, como única fuente revelada por la divinidad, siendo este texto su máxima autoridad de conducta. Reconocen la salvación como una decisión personal de creer en Jesús, consideran que los pecados pueden ser perdonados por él. Además una vez que reciben la salvación, sostienen que la perfección ${ }^{71}$ en vida es una meta alcanzable, por lo que su "nueva vida" comienza con una disciplina buscada y reconocida.

En el caso de su organización, puedo señalar que es una de las denominaciones mejor organizadas que existe, en el sentido de que trata de normar casi todos los aspectos de la vida de la congregación, tratando de anticiparse a posibles problemas. Cuentan con una especie de manual titulado: Disciplina de la Iglesia Metodista de México A.R. ${ }^{72}$ donde es posible identificar las normativas que se siguen, o por lo menos se deberían seguir, en una iglesia local. Lo que salta a la vista es una disciplina muy rígida, por ejemplo, los creyentes pueden ser acusados por distintas conductas como: irresponsabilidad, murmuración, crítica mordaz, acciones imprudentes, acciones inconvenientes, acciones impropias, carácter irascible, acciones indignas, inmoralidad, adulterio o fornicación, enseñanza doctrinal dolosa, irreverencia, desobediencia, rebeldía, blasfemia, discordia y cisma. ${ }^{73}$ Esta llamada de

\footnotetext{
${ }^{70}$ Estas prácticas las observé durante mis visitas a la Iglesia Bautista Monte Sion, ubicada en la delegación Iztapalapa, en la colonia Xalpa.

${ }^{71}$ Se dice que su denominación como metodistas se deriva de lo rigurosos que son con su vida espiritual y terrenal.

${ }^{72}$ Disponible en http://iglesia-metodista.org.mx/creemos.html (consultado el 19 de junio de 2018).

${ }^{73}$ Disciplina de la Iglesia Metodista de México, pp. 237-238. Disponible en http://iglesiametodista.org.mx/creemos.html (consultado el 19 de junio de 2018).
} 
atención tiene la intención de ayudar a los inculpados para que puedan mejorar, para lo cual, primero se les hace un llamado de atención de manera privada y, si son reincidentes, de manera pública se les señala.

Las iglesias metodistas se estructuran en obispados, los cuales se reúnen cada cuatro años para discutir la situación de las iglesias, es importante señalar que cualquier miembro de la comunidad puede participar en las reuniones, sus opiniones son escuchadas y atendidas. La Iglesia Metodista de México A.R. se relaciona con el Consejo de Iglesias Evangélicas Metodistas de América Latina (CIEMAL), el Concilio Mundial Metodista y la Iglesia Metodista Unida de los Estados Unidos de América. ${ }^{74}$ Cada iglesia es autónoma y libre de seguir perteneciendo o no a estas asociaciones, los cargos de obispos tienen una duración de 4 años y son electos por todos los miembros de la comunidad. Queda claro que a pesar de que, al parecer, la iglesia metodista es de las más rígidas dentro del cristianismo, sus reglamentos son consensuados y se reforman cada cuatro años cuando se realiza la reunión nacional.

Cuando atendemos a las peculiaridades del pentecostalismo, los bautistas y los metodistas, es clara la complejidad que existe dentro del cristianismo. A continuación argumentaré mi decisión de centrarme en la idea de un cristianismo en general. En primer lugar es claro que, por lo menos en el territorio mexicano, el término protestantismo ha pasado a ser sinónimo de evangelista o cristiano, estos tres términos los he utilizado y los utilizaré de manera indistinta en mi investigación. Entiendo por cristiano al creyente que

\footnotetext{
${ }^{74}$ Ibíd., p. 39.
} 
considera a Jesucristo como su salvador, basando su creencia en la Biblia como texto fundamental, y profesando una religión con raíces protestantes.

Centrándome en los elementos comunes que comparten todas las variantes, puedo hablar del cristianismo de manera general, ya que, las diferencias no se contraponen a sus creencias primordiales, ni tampoco han provocado una separación irreconciliable entre ellos, es decir, todos comparten la Biblia como raíz común. Todas las variantes cuentan con un pasado compartido que las une, además sus prácticas, hasta el momento, no les impiden reconocerse mutuamente como cristianos. Lo mismo ocurre con el término evangélico que: "se utiliza para enfatizar los elementos de unión entre todas las iglesias que consideran tener lazos con la reforma protestante y que se basan en la lectura exclusiva de la Biblia como fuente de toda verdad religiosa." 75

Aunado a este elemento es posible identificar la autonomía con la que las iglesias cristianas se comportan, ${ }^{76}$ a pesar de pertenecer a organizaciones nacionales o internacionales cada una adopta estrategias diferentes para adaptarse al contexto especifico en el que se encuentran. Esto explica, en parte, la búsqueda constante de llevar el mensaje Bíblico más allá de las páginas del texto, en las pintas en la calle, los Tratados Chick o las alabanzas, que son ejemplos muy claros de este fenómeno.

Es así que cuando en mi análisis salga a relucir la variante del cristianismo de alguna iglesia, pondré alguna nota aclaratoria en cuanto a este aspecto, pero no desarrollaré ni

\footnotetext{
${ }^{75}$ Carlos Garma Navarro, op. cit., 2004, p. 298.

${ }^{76}$ Cabe señalar que las iglesias se han unido en momentos clave, por ejemplo, cuando se legisló en el año de 1992 sobre la libertad religiosa. Las iglesias cristianas realizaron un frente común en la Confraternidad Evangélica de México (Conamex) y la Confraternidad de Iglesias Cristianas Evangélicas de la República Mexicana (Cofraternice). Nótese que fueron las iglesias las que eligieron la palabra "cristiana" para denominar la unión. Sin embargo, una vez que pasó ese momento clave la unión perdió fuerza en su trabajo en conjunto, las iglesias asumieron su autonomía tradicional. Cfr. Carlos Garma Navarro, op. cit., 2004, pp. $270-271$.
} 
abundaré en este elemento. Pienso que mi decisión se justifica también por la dinámica propia del cristianismo, ya que la identificación de los creyentes cómo cristianos sobrepasa la de la variante, además de que el término "cristiano" lo dota de cohesión e identidad: "Es necesario aclarar que los términos de 'cristianos' o evangélicos' son utilizados sobre todo por los miembros de las agrupaciones protestantes y pentecostales cuando desean destacar elementos de cohesión y unidad."77 A continuación detallaré los conceptos que me resultan útiles para el análisis de los elementos de mi corpus.

\footnotetext{
${ }^{77}$ Carlos Garma Navarro, "Las masculinidades en la música cristiana”, en Franco Savarino y Alejandro Pinet (coords), Movimientos sociales. Estado y religión en América Latina. Siglos XIX y XX, México, PROMEPINAH-CONACULTA, 2009, p. 72.
} 


\section{Marco teórico}

\subsection{Unidad de análisis: el enunciado}

Mi investigación se encuentra apoyada por diversos conceptos que me ayudan a realizar mi análisis de manera más concreta y profunda. El primer aspecto teórico que quiero exponer es el de la enunciación, para ello me baso en el trabajo de Émile Benveniste, quien considera que se trata de una: “[...] realización individual [que] en relación con la lengua, [se define] como un proceso de apropiación." 78 En este sentido, la teoría de la enunciación me permite abandonar la noción de "oración” (relación con lo gramatical) y tratar solamente con enunciados, entendidos como apropiaciones de la lengua que hacen los enunciadores. Esta perspectiva me permite poner atención en la acción de usar el lenguaje en una práctica social que genera un discurso, el cual nace de la Biblia, pero se traslada a otras prácticas que generan sus propios discursos que le otorgan movilidad al mensaje bíblico: "Si al mirar un texto, se empieza a prestar atención no ya a los signos, sino a otros patrones formados por sus constituyentes, y a ciertos aspectos de carácter material de sus constituyentes, entonces se abre una perspectiva distinta: la posibilidad de otros procesos significativos que actúan por debajo o al lado de los signos manifiestos del texto."79

En relación con mi tema, el enunciado me permite explicar la conexión entre el texto escrito (Biblia) y el lenguaje cotidiano. Un ejemplo de esto es el siguiente fragmento de la historieta titulada: “¡AYYY!”:

\footnotetext{
${ }^{78}$ Émile Benveniste, Problemas de lingüística general II, México, Siglo XXI, 1983, p. 84.

79 Jonathan Culler, "Hacia una lingüística de la escritura", en Nigel Fabb, Derek Attridge, Alan Durant y Colin MacCabe (comps.), La lingüística de la escritura. Debates entre lengua y literatura, Madrid, Visor, 1989, p. 186.
} 


\section{[AYYY!}

Imagen 4: Portada
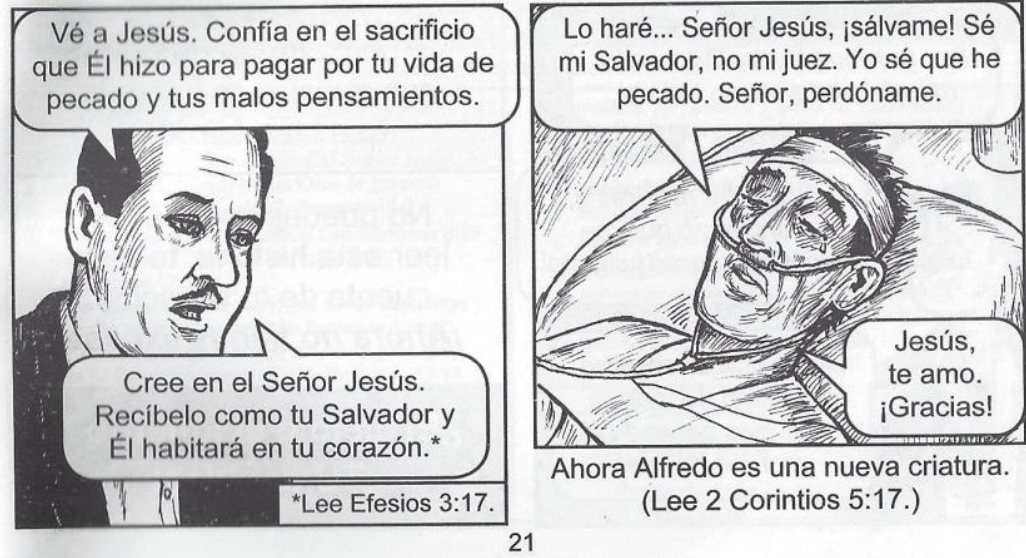

Ahora Alfredo es una nueva criatura. (Lee 2 Corintios 5:17.)

\section{Imagen 5: página 21}

En este caso mi enunciado es: “Ahora Alfredo es una nueva criatura.” En la historieta la apropiación del mensaje bíblico de 2 de Corintios 5:17 ${ }^{80}$ no la refleja de manera textual, sino que la recrea en una escena enunciativa usando elementos gráficos con texto. Para entender bien la situación del personaje, la historieta invita al lector a buscar el pasaje bíblico mencionado. Este salto de la Biblia a la historieta me permite identificar que el mensaje

\footnotetext{
${ }^{80} 2$ Corintios 5:17: "De modo que si alguno está en Cristo, nueva criatura es; las cosas viejas pasaron; he aquí todas son hechas nuevas."
} 
religioso está traspasando su ámbito tradicional. Tal como lo afirma Pierre Bourdieu para dar cuenta de la significación de los discursos, no es la gramática, ya que su verdadero sentido está en el aspecto social del lenguaje: “[...] los lingüistas no hacen más que incorporar a la teoría un objeto pre-construido cuyas leyes sociales de construcción olvidan y cuya génesis social en todo caso enmascaran $[\ldots]^{\prime 81}$

Para poder reforzar la idea de analizar más allá de la perspectiva gramatical, quiero mencionar los argumentos de Mijaíl Bajtín al respeto, el autor señala que la palabra debe considerarse en tres sentidos: como neutra, ajena y propia. La palabra neutra sólo indica su pertenencia a la lengua, la ajena en cambio, está determinada por su pertenencia a otro enunciador, y la propia es aquella que ocurre cuando: “[...] yo la uso en una situación determinada y con una intención discursiva determinada, la palabra está compenetrada de mi expresividad." ${ }^{, 82}$ Es claro que la visión neutra no es suficiente para explicar todos los alcances de los enunciados. En esto Bourdieu coincide al señalar que las palabras neutras del diccionario no tienen ninguna relación con las prácticas sociales: "Producto de la neutralización de las prácticas en que funciona, la palabra de los diccionarios no tiene ninguna existencia social $[\ldots]^{\prime \prime 83}$

En la práctica, la palabra sólo existe sumergida en situaciones, por lo tanto no hay palabras neutras, cada enunciador elige sus palabras dependiendo la situación en la que se encuentre. Esta perspectiva de análisis busca trabajar con producciones de habla, es decir

\footnotetext{
${ }^{81}$ Pierre Bourdieu, ¿Qué significa hablar? Economía de los intercambios lingüísticos, Madrid, Akal, 1985, p. 18.

${ }^{82}$ Mijaíl Bajtín, Estética de la creación verbal, México, Siglo XXI, 1999, p. 278.

${ }^{83}$ Pierre Bourdieu, op. cit., p. 14.
} 
enunciados que ya fueron dichos por un enunciador, teniendo en cuenta los elementos sociales de éstos.

Utilizando el enunciado de mi ejemplo anterior: "Ahora Alfredo es una nueva criatura", la palabra neutra se refleja en que todas las palabras de ese enunciado pertenecen al español, teniendo un significado por sí mismas. La palabra ajena muestra que el concepto "nueva criatura" pertenece a la Biblia. Por último, la palabra propia está vinculada al uso de este enunciado por parte del personaje llamado "Roberto Núñez", el cual compartió su mensaje bíblico con "Alfredo", quien es el personaje postrado en la cama del hospital.

Podemos concluir, entonces, que el individuo, usa enunciados muy particulares que reflejan su perspectiva individual pero también su pertenencia a una colectividad, una característica que se adecúa al concepto de enunciado performativo de Pierre Bourdieu, el cual contiene la idea de un enunciador que representa a una institución o a un grupo social, por lo que sus enunciados tienen cierta autoridad, que no recae en este sujeto en particular, sino en lo que personifica: "El verdadero principio de la magia de los enunciados performativos reside en misterio del ministerio, es decir, el ministerio de la delegación. Una delegación a través de la cual un agente singular, rey, sacerdote, portavoz, recibe un mandato para hablar y actuar en nombre del grupo, constituido así en él y por él."84

De este modo, un cristiano al enunciar de diferentes maneras (pintas en la calle, canciones, comics, entre otros) mensajes bíblicos, se convierte en el portavoz de toda una institución y en última instancia de su texto sagrado. Por lo que la credibilidad de sus enunciaciones no se determinará por aquél que lo enuncie, sino por la manera de ver al

\footnotetext{
${ }^{84} I b i ́ d .$, p. 49.
} 
cristianismo en su conjunto. Para ejemplificar este concepto utilizaré dos Tratados Chick en los que el mensaje que se quiere reflejar es el mismo (Dios ama a todos) y tiene la misma validez sin importar quien lo enuncie. En la imagen 6, el enunciador es un personaje que tiene cáncer y comparte el mensaje de que Dios ama a todos, por eso quiere la salvación de todos los hombres, lo cual se encuentra respaldado en 2 de Pedro 3:9 ${ }^{85}$ En el caso de la imagen 7, el enunciador es una niña que comparte el mismo mensaje que el enunciador de la imagen 6. La validez de su enunciado no radica en la persona sino en la institución que la respalda, en este caso el cristianismo y su texto sagrado, la Biblia. Cabe señalar que utilicé a estos personajes como ejemplo, sin embargo, considero que el verdadero enunciador va más allá de estos personajes ficticios, pues podría identificarse con una ideología religiosa, en este caso el cristianismo en general.
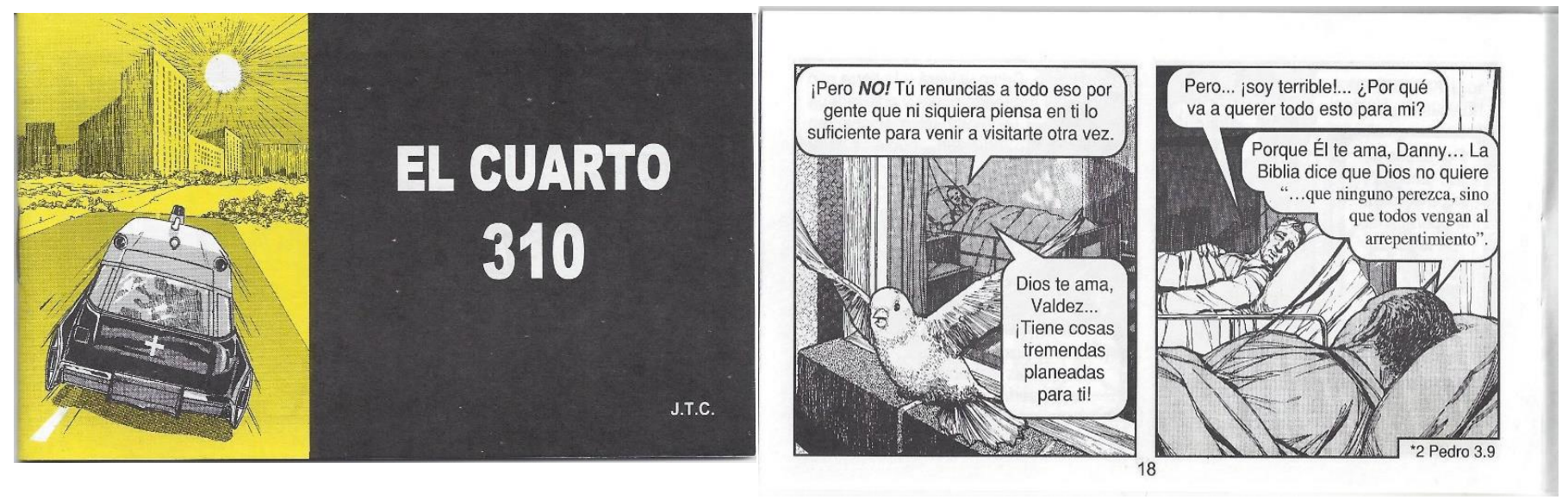

Imagen 6: "El cuarto 310"

852 de Pedro 3:9 "El Señor no retarda su promesa, según algunos la tienen por tardanza, sino que es paciente para con nosotros, no queriendo que ninguno perezca, sino que todos procedan al arrepentimiento." 


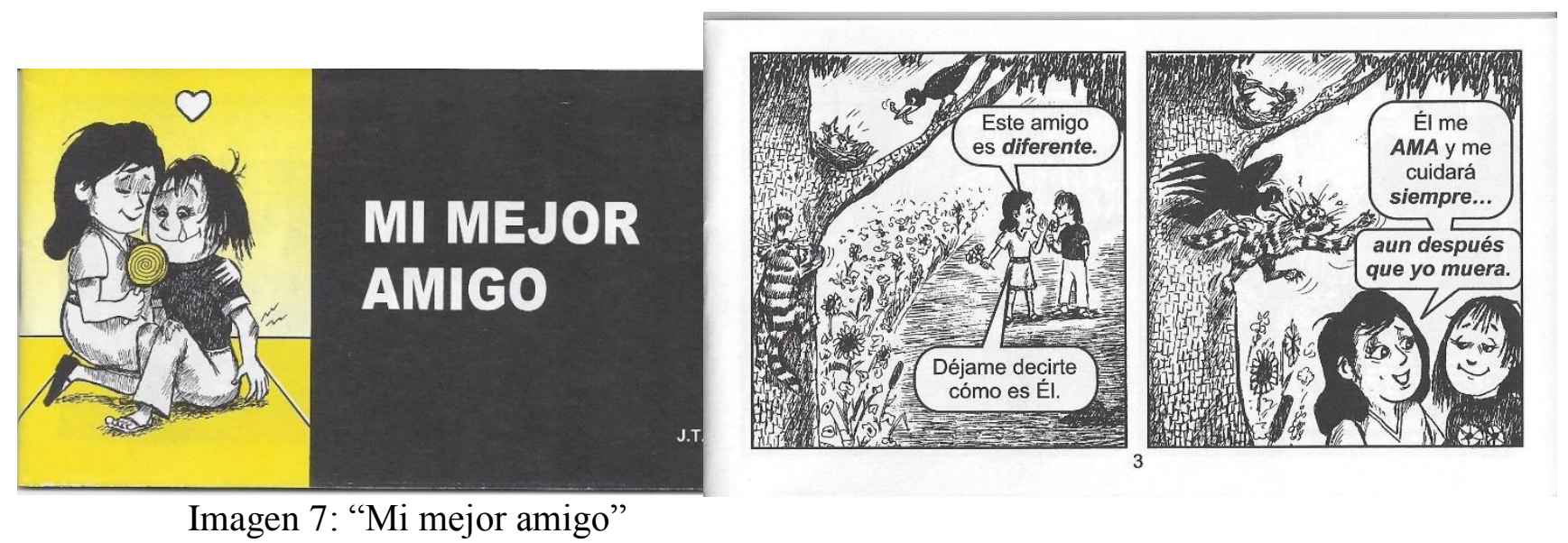

Al ser el enunciado mi unidad de análisis, me encuentro obligada a identificar al enunciador y al enunciatario dentro de las escenas enunciativas que corresponden a mi corpus (pintas en las iglesias, Tratados Chick, alabanzas). En primer lugar, considero que el enunciador que estoy investigando es la ideología religiosa (cristianismo), ya que, los enunciados que encuentro en mi corpus van más allá de la individualidad del autor propiamente dicho, puesto que el autor representa a la Iglesia, siendo su objetivo la propagación de ideas referentes a su creencia religiosa. En este sentido el cristianismo absorbe a la Iglesia y ésta al autor que representa su fe. Este enunciador cuenta con la capacidad de apropiarse del lenguaje, utilizándolo para generar enunciados con carácter religioso que tienen el objetivo principal de socializar su fe, dando a conocer su cosmovisión.

De este modo el enunciador principal, que es la ideología religiosa utiliza diferentes dispositivos, entendidos como: “. . . todo aquello que tiene, de una manera u otra, la capacidad de capturar, orientar, determinar, interceptar, modelar, controlar y asegurar los gestos, las 
conductas, las opiniones y los discursos de los seres vivos." ${ }^{\text {}}$ Con ellos el enunciador logra llegar a distintos espacios que la Biblia por sí misma no podría alcanzar, cada dispositivo cuenta con un lenguaje propio que refleja su pertenencia al ámbito religioso.

Por otro lado, el enunciatario, es decir, las o la persona que recibe los enunciados, lo considero como todo aquel que queda expuesto ante los enunciados del cristianismo, y que puede reaccionar de manera positiva, negativa o indiferente, dependiendo de su propia cosmovisión. Estos enunciados pueden tener presencia dependiendo de la escena enunciativa, que se encuentra determinada por el soporte del enunciado. De este modo, quiero mencionar cada una de las escenas que tengo contempladas en mi corpus. En el caso de las pintas en las iglesias, se trata de una escena urbana; para los Tratados Chick la escena es literaria, específicamente perteneciente a la cultura popular; para las canciones, la escena pertenece al ámbito musical, concretamente al género de las alabanzas. Cada una de ellas presenta esa capacidad de trascender el ambiente de la Iglesia y sobrepasar por mucho la capacidad de alcance que tiene la Biblia como libro.

Teniendo en cuenta al enunciador, al enunciatario y a la escena enunciativa, es momento de hablar de la dinámica entre estos tres conceptos. En primer lugar, el enunciador busca nuevas maneras de propagar su fe, tomando en cuenta los cambios propios del contexto. Considero que el objetivo primordial es propagar los mensajes bíblicos fuera del entorno de la iglesia. En este tránsito, los mensajes, al pertenecer a la Biblia, tienen cierta naturaleza arcaizante, sin embargo, al pasar a otros soportes se mantiene la esencia bíblica, pero tienen un carácter más cercano a la cotidianidad, lo cual permite que sea más fácil que

\footnotetext{
${ }^{86}$ Giorgio Agamben, “¿Qué es un dispositivo?”, en Sociología, número 73, mayo-agosto 2011, p. 257.
} 
sean conocidos y aceptados por más personas. El deseo de propagar el cristianismo determina las múltiples escenas enunciativas y adaptaciones de las enseñanzas bíblicas que hace el enunciador. El lenguaje visto desde esta perspectiva va más allá de los hablantes o las cosas que se dicen, de modo que se podría considerar un sistema versátil que es capaz de producir enunciados infinitos (lo que se dice) por medio de caracteres finitos (lengua). De esta manera, un análisis enunciativo se preocupa por explicar por qué ciertos enunciados son emitidos en un espacio y tiempo determinado, además de que se trata de buscar las conexiones con otros enunciados. $^{87}$

De este modo el enunciatario, en un primer momento, se enfrenta a los enunciados del cristianismo y los interpreta según su forma de ver el mundo, es aquí donde la imagen que tiene del cristianismo define su afinidad o rechazo ante estos enunciados. Junto al nivel de rechazo o aceptación, considero que también se encuentra la comprensión que puede tener de los mensajes, mientras más simbólico, el enunciatario tendrá que tener más conocimiento bíblico para poder interpretar los enunciados. Los enunciatarios pueden estar más expuestos a los enunciados del cristianismo dependiendo de los ámbitos que alcance el enunciador. En este sentido resulta interesante reconocer la capacidad que tienen los individuos que pertenecen a alguna iglesia de usar la lengua para manifestar su pertenencia al cristianismo.

Bajo esta perspectiva, la enunciación se nos muestra como un concepto muy versátil que se puede adaptar a múltiples objetos de investigación, ya que los enunciados van más allá de lo dicho, reflejan una práctica social que se encuentra determinada de muchas formas

\footnotetext{
${ }^{87}$ Cfr. Michel Foucault, La arqueología del saber, Siglo XXI, México, 1970, pp. 33-49.
} 
y que el enunciador manifiesta en cada una de sus construcciones. Todos estos enunciados se pueden organizar en géneros discursivos, tal como lo explico a continuación.

\subsection{Género discursivo religioso}

Todos los enunciados que producen las iglesias cristianas pueden clasificarse y ordenarse bajo la perspectiva teórica de Mijaíl Bajtín, quien considera que un género discursivo: "elabora sus tipos relativamente estables de enunciados[...]"88 En consecuencia es posible definir los aspectos generales de un género discursivo religioso que, en primer lugar, debe caracterizarse como un género discursivo complejo, es decir secundario, el cual va más allá de la comunicación inmediata: “[...] surge en condiciones de la comunicación cultural más compleja." 89 Se puede decir que existen diferentes géneros discursivos basados en el cristianismo, entre ellos las canciones, los Tratados Chick, las pintas en la calle e incluso las palabras de las conferencias que se dan en la congregación. Cada uno de estos elementos cuenta con diferentes escenas enunciativas en las que los cristianos usan este discurso en su vida diaria.

Los conceptos de Mijaíl Bajtín me permiten identificar qué tipo de género discursivo contiene cada discurso de mi corpus, donde es posible reconocer que en casi todos los casos se trata de géneros discursos complejos, porque refieren a la Biblia. Todos estos géneros discursivos tienen en común el elemento religioso, reflejan los mensajes bíblicos, sólo que cada uno de ellos tiene distintos soportes. Tradicionalmente el soporte de la Biblia es el papel,

\footnotetext{
${ }^{88}$ Mijaíl Bajtín, op. cit., p. 248.

${ }^{89}$ Ibíd., p. 250.
} 
sin embargo, en su acción de propagación, con estos géneros discursivos vemos cómo el espacio habitual que ocupaba la Biblia (casa e iglesia) es traspasado mediante otros soportes.

Por ejemplo, las pintas en la calle tienen un soporte en la barda que ocupan, infiltrándose en el espacio público, donde es normal encontrarse con anuncios, mantas publicitarias y grafitis, lo que no es habitual es que se refieran a la Biblia. En el caso de los Tratados Chick, aunque el soporte es el papel, éstos por su naturaleza dinámica, en su utilización de elementos gráficos (dibujos) y textuales, son capaces de alcanzar espacios impensados por la Biblia, por ejemplo, la escuela o el trabajo. El soporte de las canciones puede ser físico (cd’s) o digital (Spotify, YouTube, entre otros), por su naturaleza portátil siempre pueden acompañar al creyente y al no creyente cuando es ocupado un espacio común.

Si se observan los diferentes géneros discursivos podemos darnos cuenta de que esta religión se está incorporando a espacios comunes. Para entender mejor esta situación, elegí un concepto que une todos los elementos de mi corpus, me refiero a la formación discursiva de Michel Foucault, quien lo concibe como un grupo de enunciados que se pueden formar a través de los sistemas de dispersión, entendidos éstos como rupturas en los modelos convencionales de establecimiento de formaciones discursivas. Estas dispersiones permiten encontrar nuevas conexiones que tradicionalmente no son aceptadas. Así, los enunciados salen de su orden genérico y se van a otras formaciones discursivas que, tal vez, no habían sido tomadas en cuenta. ${ }^{90}$

\footnotetext{
${ }^{90}$ Cfr. Michel Foucault, op. cit., pp. 50-64.
} 
Cabe aclarar que estas nuevas conexiones no anulan las tradicionales sino que las complementan en una coexistencia reconocida. Es por ello que se pueden relacionar autores que no compartieron ni el mismo tiempo, ni el mismo espacio geográfico, como es el caso de la conexión entre la Biblia, y los Tratados Chick, las canciones o las pintas en espacios públicos que se realizan en la actualidad. Dicho de otra manera, existe una coexistencia de los enunciados bíblicos con los que aparecen en los elementos del corpus. En el caso de mi investigación el discurso se encuentra determinado por la formación discursiva religiosa que cuenta a su vez con enunciados múltiples que están relacionados con enunciados de otras formaciones discursivas que dan lugar a la producción de otros discursos.

En suma, las tesis de Michel Foucault me permiten justificar el planteamiento de mi investigación, con respecto al hecho de que la religión se encuentra presente en espacios y esferas diversas de la vida del creyente (incluso del no creyente), formando relaciones discursivas en su vida cotidiana. Es evidente que las nociones tradicionales de la lingüística no coinciden con estos planteamientos porque el problema que se trata aquí se refiere a fenómenos culturales, en el caso específico de mi investigación, el uso del lenguaje por parte de los cristianos.

La utilidad de una perspectiva enunciativa, en lugar de gramatical, me permite un análisis de la dinámica discursiva en el espacio social, donde las prácticas culturales se vinculan con espacios que hacen uso de lenguajes diversos; es decir, de enunciados que se enmarcan en escenas enunciativas que sitúan a enunciadores y enunciatarios en distintas acciones comunicativas. 


\section{Uso de diferentes soportes por el cristianismo}

Este capítulo tiene la finalidad de presentar el análisis que realicé de los elementos de mi corpus, entendido como el conjunto de datos lingüísticos que muestran cómo está funcionando la propagación de la fe cristiana en términos de la traducción de un lenguaje escrito a un lenguaje coloquial que trasciende las fronteras de los espacios tradicionales de la religión. Este fenómeno refleja una de los principales preceptos cristianos, me refiero al que establece la obligación de buscar nuevos creyentes. Esta dinámica que muestra el cristiano al momento de socializar su fe y las diversas formas en las que los mensajes bíblicos trascienden las páginas de la Biblia me llevó a definir mi corpus tratando de incluir enunciados provenientes de diversos soportes y escenas enunciativas:

1. Tratados Chick. Historietas que reflejan enseñanzas bíblicas

2. Alabanzas. Canciones dedicadas a Dios

3. Pintas en la calle con elementos religiosos. Ubicadas en las fachadas o cercanías de las iglesias

Bajo esta mirada, los Tratados Chick al ser historietas que reflejan enseñanzas bíblicas, muestran el deseo de acercar a los demás, de manera fácil, los conocimientos que contiene la Biblia. Las alabanzas, se dirigen en el mismo sentido, junto al recurso nemotécnico que tienen por sí mismas. En las pintas en la calle con elementos religiosos, observamos el deseo de sintetizar enseñanzas bíblicas.

Una pregunta que salta a la vista es ¿por qué los cristianos buscan propagar los mensajes bíblicos? Para responder a la pregunta pienso utilizar dos elementos en conjunto, la condición histórica y la cosmovisión cristiana. Uno de los principales preceptos bíblicos dentro del cristianismo es el de predicar el evangelio y extender la fe cristiana. Esta misión ha provocado que los cristianos busquen constantemente nuevas formas de difusión de su fe. 
En este sentido mi corpus considera manifestaciones diversas de ese deseo de propagación de la fe.

Así, en el capítulo muestro inicialmente el análisis de las pintas en la calle, donde partí de una perspectiva histórica. Para entender esta práctica cultural me remontó a las catacumbas romanas, en donde los primeros cristianos trataron de dejar plasmada en la pared su cosmovisión. Con este antecedente, me ocupo en explicar el proceso que llevé a cabo para la obtención, la clasificación y el análisis de las pintas de la calle. En segundo lugar, me ocupo de los Tratados Chick, donde comienzo con la explicación del origen, organización y alcance de la editorial Chick Plublications, además de un análisis de su historieta. Por último, me encargo del análisis de las alabanzas señalando la función que cumplen en el proceso de socialización de la fe, así como las semejanzas y diferencias que encontré en ellas. Sin más que añadir, a continuación me ocupo de analizar cada elemento de mi corpus. 


\subsection{Pintas en la calle}

Como ya mencioné anteriormente, uno de los principios básicos del cristianismo es la evangelización y por ende la socialización de su fe. En este apartado me dedicaré a analizar las pintas con elementos religiosos que se encuentran en las fachadas de las iglesias o en sus cercanías. Para comprender la función que juegan quiero retomar los primeros ejemplos que se pueden rastrear en la historia del cristianismo y que afortunadamente sobrevivieron hasta nuestros días, me refiero a las catacumbas romanas.

Uno de los primeros ejemplos de las estrategias para propagar la fe cristiana fuera del ámbito de la iglesia, fueron las imágenes que se pintaban en las tumbas de las catacumbas romanas, aproximadamente entre el año 200 y 300 d. de C. Recordando lo que mencioné en el capítulo uno, cronológicamente, estas imágenes encuadran perfectamente en el contexto de la llamada crisis del siglo III, en donde el cristianismo era perseguido por el Imperio romano. De esta forma se entiende que las imágenes se plasmaran en catacumbas subterráneas fuera del alcance de las autoridades imperiales: "Nos encontramos en una época de fuerte analfabetismo, con el handicap de tener que transmitir los valores de la nueva religión para favorecer su predicación y la adhesión de numerosos fieles. Estas imágenes tienen un valor aleccionador y doctrinal." 91

La clandestinidad y el analfabetismo general de la población marcaron el carácter de las pintas de las catacumbas que, las condicionaba a ser simbólicas y sintéticas en cuanto a los mensajes bíblicos que se pretendían transmitir. Así, cumplían con dos funciones específicas, la más inmediata, buscaba aleccionar, la otra, que requería de tiempo, consistía

\footnotetext{
${ }^{91}$ Silvino Strano, "En torno a las catacumbas cristianas de Roma: historia y aspectos iconográficos de sus pinturas”, en Boletín de Arte, núm. 26-27, 2005-2006, p. 26.
} 
en forjar los símbolos del cristianismo para provocar el reconocimiento de su identidad en el momento de usarlos y reconocerlos. A continuación, presento algunos ejemplos de símbolos que aparecen más recurrentemente en las catacumbas (cabe señalar que actualmente las catacumbas tienen nombres de mártires de la tradición católica, sin embargo, cronológicamente pertenecen a la tradición cristiana):

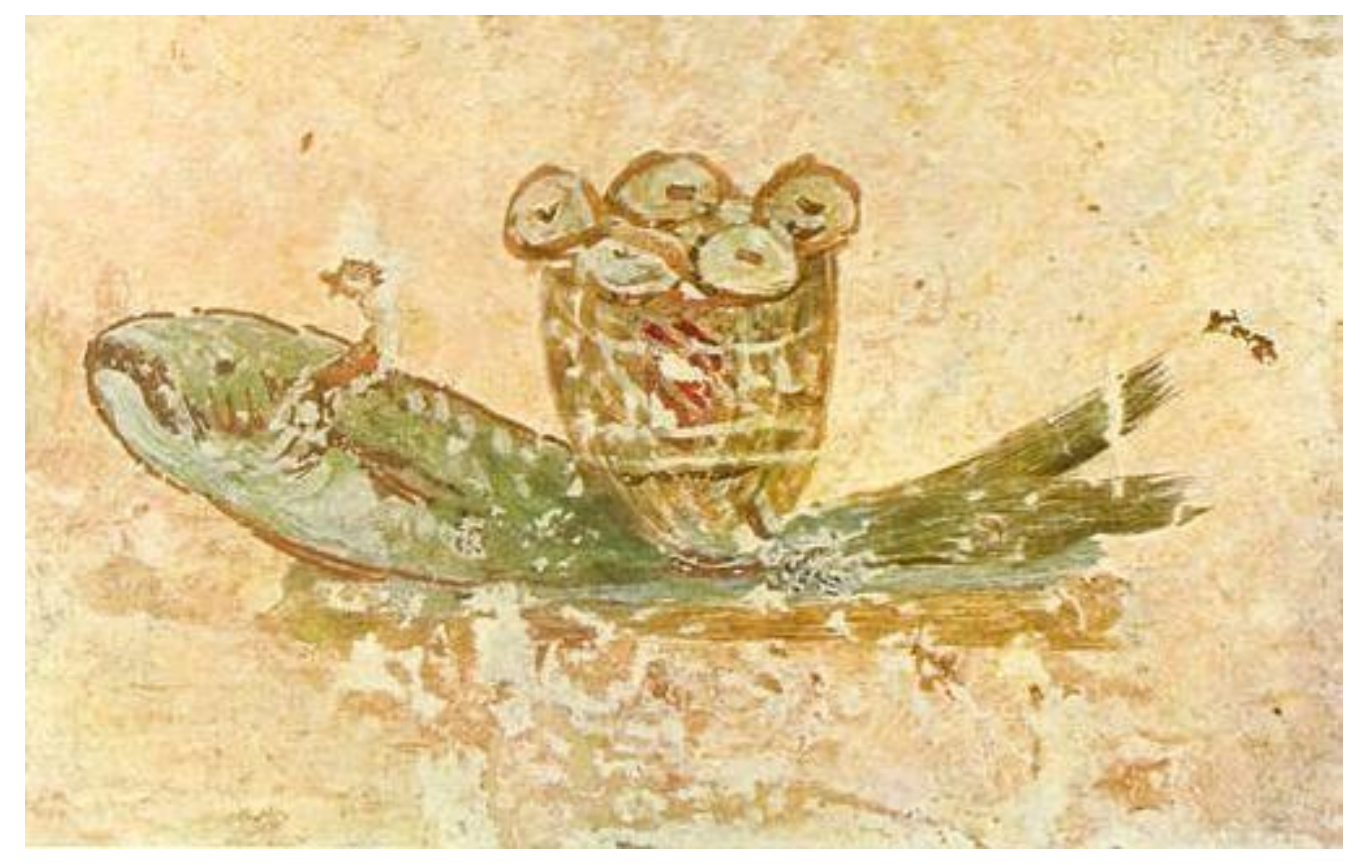

Imagen 8 . Pez y cesta de panes en la catacumba de San Calisto. ${ }^{92}$

En la imagen 8 podemos ver el inicio de la tradición de conectar el cristianismo con el símbolo del pez, ${ }^{93}$ además de la cesta con los panes representando el milagro de la multiplicación de $\operatorname{los}$ alimentos $^{94}$ realizado por Jesús. Se puede decir que en una misma

\footnotetext{
92 Tomado de Silvino Strano, op. cit., p.30.

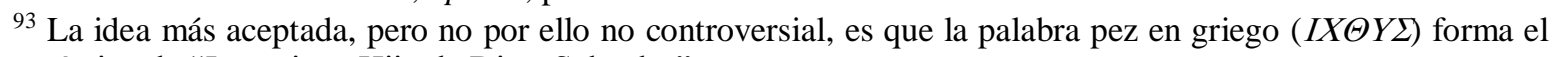
acróstico de "Jesucristo, Hijo de Dios, Salvador"

${ }^{94}$ Mateo 14:15-21:“15 Y cuando fue la tarde del día, se llegaron a él sus discípulos, diciendo: El lugar es desierto, y el tiempo es ya pasado: despide las gentes, para que se vayan por las aldeas, y compren para sí de comer. 16 Y Jesús les dijo: No tienen necesidad de irse: dadles vosotros de comer. 17 Y ellos dijeron: No tenemos aquí sino cinco panes y dos peces.18 Y él les dijo: Traédmelos acá. 19 Y mandando a las gentes recostarse sobre la hierba, tomando los cinco panes y los dos peces, alzando los ojos al cielo, bendijo, y partió y dio los panes a los discípulos, y los discípulos a las gentes. 20 Y comieron todos, y se hartaron; y alzaron lo
} 
imagen tenemos un elemento simbólico y aleccionador de un pasaje bíblico. Como podrá observar el lector de estos dos elementos incorporados en la imagen 8, el más representativo es el del pez, símbolo que ha trascendido el tiempo siendo el más distintivo de la filiación al cristianismo, es reconocido por cristianos y no cristianos.

Otro ejemplo de las imágenes de las catacumbas lo tenemos en la imagen 9, se observa la figura de un pastor de ovejas, el cual hace referencia a Jesús en su labor de cuidar de su rebaño, en este sentido la imagen de líder espiritual salta a la vista, al igual que en la imagen anterior, se trata de aleccionar sobre un pasaje bíblico ${ }^{95}$ con una imagen. De nueva cuenta es clara la intención de sintetizar una enseñanza religiosa, y es interesante observar la forma en que una imagen puede contener una significación tan compleja y remitir a enseñanzas bíblicas, tomando en cuenta el contexto de la persecución del cristianismo, que nos permite comprender porque se tuvo que recurrir a esta estrategia de propagación de la fe.

Imagen 9. El buen pastor en la catacumba de la Vía latina ${ }^{96}$

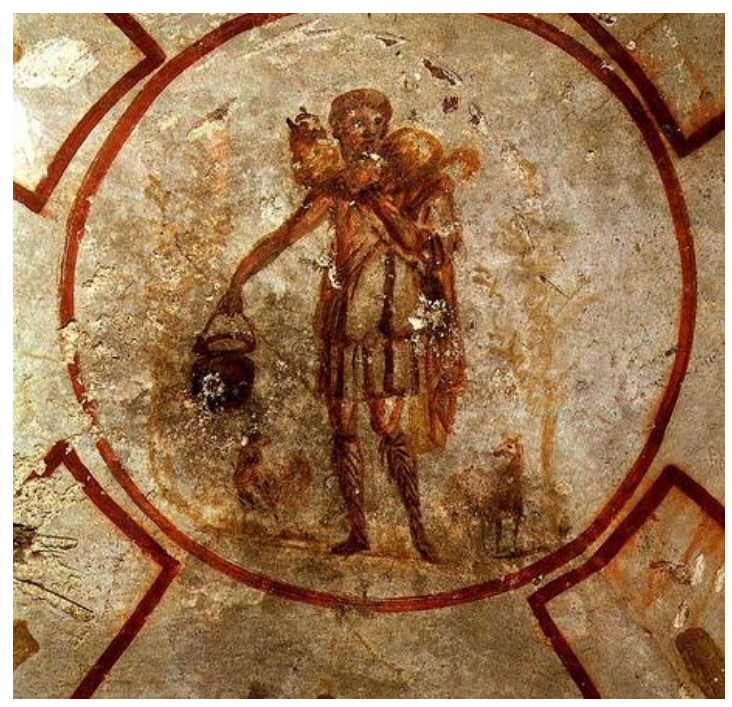

que sobró de los pedazos, doce cestas llenas. $21 \mathrm{Y}$ los que comieron fueron como cinco mil hombres, sin las mujeres y los niños."

${ }^{95}$ Juan 10:11 "Yo soy el buen pastor; el buen pastor su vida da por las ovejas."

${ }^{96}$ Tomado de Silvino Strano, op. cit., p.31. 


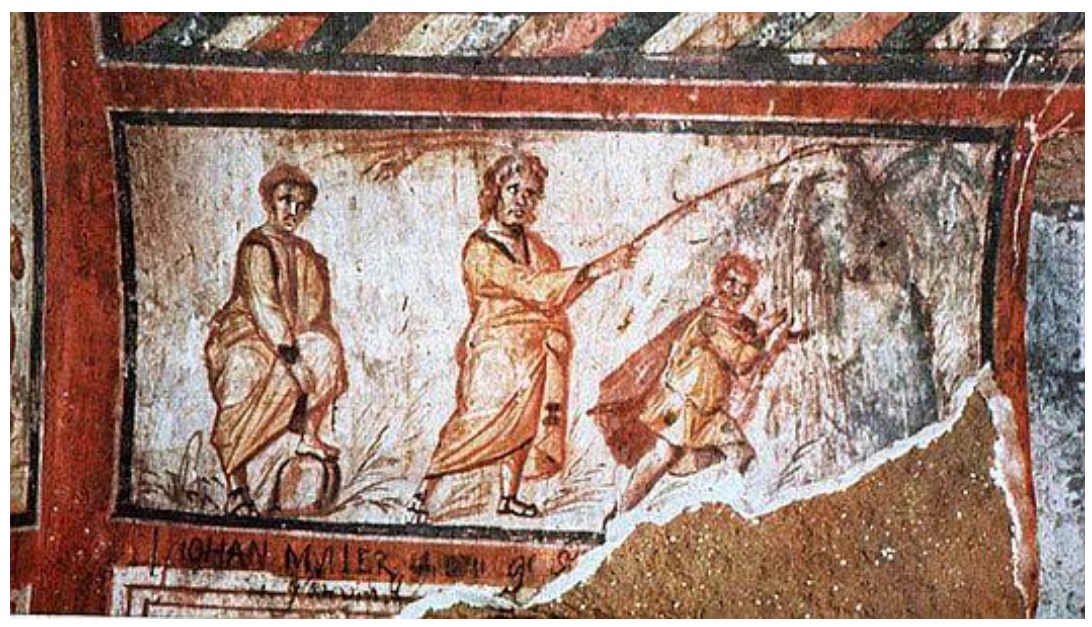

Imagen 10. Moisés haciendo brotar agua de la roca, Catacumba de San Calisto. ${ }^{97}$

Continuando con los ejemplos de las representaciones gráficas de las catacumbas, lo interesante de la imagen 10 es que muestra una escena del Antiguo Testamento, específicamente el momento en que Moisés golpea una roca para poder dar de beber a los judíos que lo acompañaban por el desierto en su camino a la tierra prometida. ${ }^{98}$ De este modo vemos que las enseñanzas bíblicas trasmitidas en las catacumbas recogían tradiciones del Antiguo y del Nuevo Testamento. En general, de la tradición de las catacumbas puedo resaltar ese deseo que mostraron los cristianos de propagar su fe a través de imágenes que sintetizaban sus creencias, en un momento de persecución en que las imágenes simbólicas en catacumbas subterráneas fue la solución encontrada por los seguidores de las enseñanzas de Jesús para seguir sumando adeptos a su fe.

\footnotetext{
${ }^{97}$ Tomado de http://elartepaleocristiano.blogspot.com/2012/12/catacumbas-de-san-calixto-fresco.html (consultado el 1 de junio de 2018).

${ }^{98}$ Números 20:9-11 "9 Así que Moisés hizo lo que se le dijo. Tomó la vara del lugar donde se guardaba en la presencia del Señor. 10 Luego él y Aarón mandaron a llamar al pueblo a reunirse frente a la roca. « ¡Escuchen, ustedes rebeldes! — gritó—. ¿Acaso debemos sacarles agua de esta roca?». 11 Enseguida Moisés levantó su mano y golpeó la roca dos veces con la vara y el agua brotó a chorros. Así que toda la comunidad y sus animales bebieron hasta saciarse."
} 
Pienso que los elementos de mi corpus se pueden unir con estos ejemplos tan lejanos en el tiempo. Ambos muestran el deseo de trascender el ámbito de la iglesia, acercando a los enunciatarios con los elementos de la fe cristiana, más allá de las páginas de la Biblia o un servicio dado en una iglesia. Así, las pintas en la calle pueden verse como herederas directas de las catacumbas en el sentido de que buscan mostrar sintéticamente algún pasaje bíblico. En la actualidad, leer no resulta un problema para la mayoría de la población, por lo que es más eficaz reproducir un pasaje bíblico, aunque eso no quiere decir que no exista la transformación en ese pasaje representado, por ejemplo el cambio de persona gramatical es lo más común, tal y como lo explico en este apartado.

Para la obtención de mi corpus de pintas, tomé en cuenta el padrón de asociaciones religiosas registradas en la Dirección General de Asociaciones Religiosas, que es una dependencia de la Secretaría de Gobernación, donde se registran asociaciones religiosas muy diversas que van desde el catolicismo hasta el budismo. El documento tiene tres campos: nombre de la asociación, dirección y nombre del representante o representantes legales. Esta herramienta no incluye una clasificación donde distinga cada religión, sólo muestra un listado de ellas, por lo cual me vi en la necesidad de ir descartando una por una las asociaciones religiosas que no son cristianas. A continuación, para darle una idea más precisa al lector, incluí un ejemplo de la distribución de la información en el padrón: 


\begin{tabular}{|c|c|c|}
\hline$\frac{\text { SEGOB }}{\text { sicketania De }}$ & $\begin{array}{l}\text { IRECTORIO DE ASOCLACIONES RELIGIOSAS } \\
\text { POR ENTIDAD FEDERATIVA } \\
27 / \text { oct } / 2017\end{array}$ & $\begin{array}{l}\text { Dirección General de } \\
\text { Asociaciones Religiosas }\end{array}$ \\
\hline Clave SGAR y Asociación Religiosa & Domicilio Legal & Representante o Apoderado Legal \\
\hline \multicolumn{3}{|l|}{ Entidad Federativa: CIUDAD DE MEXICO } \\
\hline $\begin{array}{l}\text { SGAR10:1016 IGLESLA EVAANGELICA PENTECOSTES } \\
\text { PENIEL Y SUS CONGREGACIONES } \\
\end{array}$ & $\begin{array}{l}\text { CALLE } 25 \text {, NUMERO 146, COLONIA OLIVAR DEL CONDE } 2 \text { A SECCTÓN, } \\
\text { ALVARO OBREGON, CP. 1408, Tel. }\end{array}$ & PABLO MONROY \\
\hline \multirow[t]{2}{*}{$\begin{array}{l}\text { SGAR101893 INTEGRACION DE IGLESLAS CRISTIANAS } \\
\text { AISIONERAS }\end{array}$} & $\begin{array}{l}\text { CALZADA PROFESOR MGGUEL LERDO DE TEJADA No 88-3, COLONIA } \\
\text { SAN FRNCISCO TETECALA, AZCAPOTZALCO, C.P. 2730, Tel } 5724875 \\
6738140\end{array}$ & ANTONIO GUIIERREZ VIILAR \\
\hline & & JORGE LENNART ROBLES ANDERSON \\
\hline \multirow[t]{5}{*}{$\begin{array}{l}\text { SGAR10:195 IGLESLA EVANGELICA PENTECOSTES } \\
\text { "SILOE" Y SUS CONGREGACIONES } \\
\end{array}$} & $\begin{array}{l}\text { AV. VASCO DE QURROGA N } 1724, \text { COLONIA SANTA FE, ALVARO } \\
\text { OBREGON, C. 1210, Tel } 5277448455702341\end{array}$ & DAVID ENRIQUEZ NAVARRETE \\
\hline & & DAVID ENRIQUEZ OLGUIN \\
\hline & & JOEL CUAUTLE SANCHEZ \\
\hline & & MARIO ANTONIO DLAZ DE LEON LOPEZ \\
\hline & & RUBEN ENRIQUEZ NAVARRETE \\
\hline \multirow[t]{2}{*}{$\begin{array}{l}\text { SGAR102:115 IGLESLA GENTE NUEVA DE LA PALABRA } \\
\text { IIVIENTE }\end{array}$} & $\begin{array}{l}\text { HUACHNANGO, DENIIFICADO COMO LOTE 10, MANZANA } 11 \text {, } \\
\text { COLONIA DEL MAR, TLAHUAC, C P. 13270, Tel. 4444-9073 }\end{array}$ & MA GUADALUPE CHAVARRIA OLVERA \\
\hline & & SILVERIO MELENDEZ DOMINGUEZ \\
\hline $\begin{array}{l}\text { SGAR/102/93 FRATERNIDAD DE IGLESLAS CRISTLANAS } \\
\text { UNDAS }\end{array}$ & $\begin{array}{l}\text { RODOLFO USTGLI No } 1559 \text {, COLONIA SECTOR POPULAR, } \\
\text { ZTAPALAPA, C.P. } 9060 \text {, Tel. } 55824328\end{array}$ & HUGO ALVAREZ PEREZ \\
\hline $\begin{array}{l}\text { SGAR } 10: 295 \text { IGLESLA BETHEL Y SUS } \\
\text { CONGREGACIONES }\end{array}$ & $\begin{array}{l}\text { CARLOS B. ZEIINA N 92, COLONIA ESCANDON, MIGUEL HIDALGO, } \\
\text { C. } 11800 \text {, Tel. }\end{array}$ & DAVID ENRTQUEZ NAVARRETE \\
\hline \multirow[t]{3}{*}{$\begin{array}{l}\text { SGGAR } 103293 \text { "AGRUPACION NACIONAL BAUTISTA } \\
\text { AISIONERA" }\end{array}$} & $\begin{array}{l}\text { CALZADA MAGDALENA MIXHUCA No 28, COLONIA MAGDALENA } \\
\text { MIXHUCA, VENUSTIANO CARRANZA, CP. 7969, Tel. } 55516499 \\
55514537\end{array}$ & RUBEN MORENO FRANCO \\
\hline & & SERGIO ESTRADA DELGADHLO \\
\hline & & VICTOR BIBI GUZMAN ZANI \\
\hline SGAR 10:495 IGLESLA BELENY SUS CONGREGACIONES & $\begin{array}{l}\text { AV CAMDNO REAL DE TOLUCA N" } 178 \text {, COLONIA JOSE MARIA PLNO } \\
\text { SUAREZ, ALVARO OBREGON, CP. 1140, Tel. }\end{array}$ & ARTURO DAVILA ROMERO \\
\hline \multirow[t]{3}{*}{ SGAR10493 IGLESLA DE DIOS EN MIEXCO } & $\begin{array}{l}\text { AV. LOPEZ MATEOS N" } 174 \text {, COLONIA ADOLFO LOPEZ MATEOS, } \\
\text { VENUSTLANO CARRANZA, CP. } 15670 \text {, Tel. } 5758721255421081 \\
\end{array}$ & HUGO MEDINA TORRES \\
\hline & & IGNACTO PEREZ FUENTES \\
\hline & & OTHONIEL PEREZ FUENTES LECHUGA \\
\hline $\begin{array}{l}\text { SGAR } 10-595 \text { IGLESLA EBEN-EZER Y SUS } \\
\text { CONGREGACIONES }\end{array}$ & $\begin{array}{l}\text { NORTE 54-A No. } 3712 \text { COL. EMIIIIANO ZAPATA, GUSTAVO A. } \\
\text { MADEROO, C. } 7889 \text {, Tel. }\end{array}$ & RAFAEL REYES CARDENAS \\
\hline \multirow[t]{3}{*}{ SGAR106/93 IGLESLA CRISTLANA "RAYO DE LUZ" } & $\begin{array}{l}\text { AV } 5 \text { DE MAYO No } 45 \text { COLONA SAN BARTOLOME XCOMULCO, } \\
\text { MIIPA ALITA, CP. } 12250 \text {, Tel } 916417453655172623\end{array}$ & FRANCISCO MEDINA OSORTO \\
\hline & & GABRIIIL SANCHEZ VELAZQUEZ \\
\hline & & GONZALO LOPEZ FERNADEZ \\
\hline
\end{tabular}

Imagen 11. Directorio de asociaciones religiosas, disponible en http://www.asociacionesreligiosas.gob.mx/work/models/AsociacionesReligiosas/pdf /Numeralia/AR_por_EF_DF.pdf (consultado el 10 de diciembre de 2017).

Una vez identificadas las iglesias cristianas, mi primera clasificación consistió en agruparlas por delegación política, ahora alcaldías. ${ }^{99}$ Del total de 384 iglesias que encontré, la distribución se presentó de la siguiente manera: 20 iglesias en Álvaro Obregón, 25 en Azcapotzalco, 35 en Benito Juárez, 29 en Coyoacán, 3 en Cuajimalpa, 37 en Cuauhtémoc, 55 en Gustavo A. Madero, 23 en Iztacalco, 60 en Iztapalapa, 6 en Magdalena Contreras, 21 en Miguel Hidalgo, 2 en Milpa Alta, 10 en Tláhuac, 17 en Tlalpan, 25 en Venustiano Carranza y 16 en Xochimilco.

${ }^{99}$ Este cambio se estableció en la Constitución Política de la Ciudad de México en octubre de 2018. 
El segundo paso consistió en dividir las delegaciones por zonas económicas, para lo cual me apoyé en el Informe de pobreza y evaluación en el Distrito Federal 2012, ${ }^{100}$ publicado y realizado por el Consejo Nacional de Evaluación de la Política de Desarrollo Social (CONEVAL). De este modo, a las delegaciones con más índice de población en pobreza las denominé con el nombre de BAJA con un total de 162 iglesias, ubicadas en Iztapalapa, Gustavo A. Madero, Álvaro Obregón, Tlalpan y Tláhuac. En el rango de MEDIA con 103 iglesias, están Venustiano Carranza, Xochimilco, Cuauhtémoc, Iztacalco y Milpa Alta. Las de menor índice de pobreza las agrupé como zona ALTA con 119 iglesias, repartidas en Benito Juárez, Miguel Hidalgo, Cuajimalpa, Coyoacán, Azcapotzalco y Magdalena Contreras. Cabe señalar que para una división más precisa sería necesario tomar más parámetros socioeconómicos de los habitantes de estas delegaciones, lo cual implicaría un trabajo de campo mejor realizado, sin embargo, esta decisión de dividir las delegaciones de esta manera apoyándome en el CONEVAL fue meramente organizativa.

Una vez clasificadas la iglesias me dispuse a visitar cada una de las ellas, se me presentaron diferentes circunstancias adversas, la primera de ellas fue la gran cantidad de territorio que debía recorrer para completar mi corpus. Además de esto, una vez que me encontraba en la iglesia muchas veces me negaron la posibilidad de tomar fotos sin previa autorización y entrevista con el Pastor. Esto provocó que la recolección de datos fuera muy lenta porque era común que el Pastor no estuviera disponible para recibirme. Por estas circunstancias, decidí utilizar google maps, una aplicación de localización satelital, puesto que las imágenes con las que cuenta me resultan de utilidad y me permiten revisar iglesias

\footnotetext{
${ }^{100}$ Disponible en https://www.coneval.org.mx/coordinacion/entidades/Documents/Informes\%20de\%20pobreza\%20y\%20evalu aci\%C3\%B3n\%2020102012_Documentos/Informe\%20de\%20pobreza\%20y\%20evaluaci\%C3\%B3n\%202012 _Distrito\%20Federal.pdf (consultado el 18 de noviembre de 2017).
} 
muy distantes entre sí. A pesar de que ésta herramienta digital es útil, tiene ciertas limitantes. En primer lugar, no todas las zonas cuentan con imágenes actualizadas, en ocasiones las últimas fotografías son del año 2005, lo cual dificulta la ubicación exacta de las iglesias, imposibilitando esta acción, puesto que muchas veces la fachada no corresponde a la de una iglesia porque en el año de la foto todavía no existía. Otro problema que se puede mencionar es que no en todas las zonas existe la posibilidad de obtener imágenes; por ejemplo, en cerradas o calles privadas no se cuenta con imágenes, otras veces las fachadas no son visibles porque hay obstáculos que impiden tener una buena visión de ésta, pues a menudo los árboles tapaban la vista. También se dio el caso de que algún carro obstruyera la visibilidad o algunas señales de tránsito impidierán tener una imagen completa de la fachada.

Una vez reconocidas estas limitaciones, me dediqué a determinar los parámetros que iba a tomar en cuenta en mi análisis de cada una de las fachadas, los cuales quedaron de la siguiente manera:

1.-Semiótica del mensaje: distinguir las fachadas que contengan pintas con texto, de aquellas donde sólo aparece el texto combinado con una imagen

2.-Zona económica: conocer en qué zona era más recurrente el uso de pintas

3.- Contenido del mensaje: distinguir si se trata de un mensaje de salvación, condenación o sólo informativo (como anuncios o eventos que organiza la iglesia)

4.-Factor bíblico: la pertenencia de los versículos que aparecen en las bardas al Antiguo o al Nuevo Testamento

5.- Forma de los mensajes en las fachadas de las iglesias: señalar si hay paráfrasis, son textuales o si sólo se encontraba presente el nombre de la iglesia (ausencia de mensajes) con respecto a la Biblia

Para realizar mi análisis cuantitativo utilicé el programa Golvarb, ${ }^{101}$ con el fin de encontrar los elementos más recurrentes. A continuación menciono los patrones que encontré

\footnotetext{
${ }^{101}$ Software utilizado para realizar análisis probabilísticos.
} 
en las pintas, el primero es la reproducción textual de un versículo de la Biblia, el cual está representado en la imagen 12, específicamente se trata de la Iglesia Bautista Cabsel Dios Reúne, ubicada en Iztapalapa, cuya fachada reproduce textualmente el versículo bíblico Juan $8: 32 .^{102}$

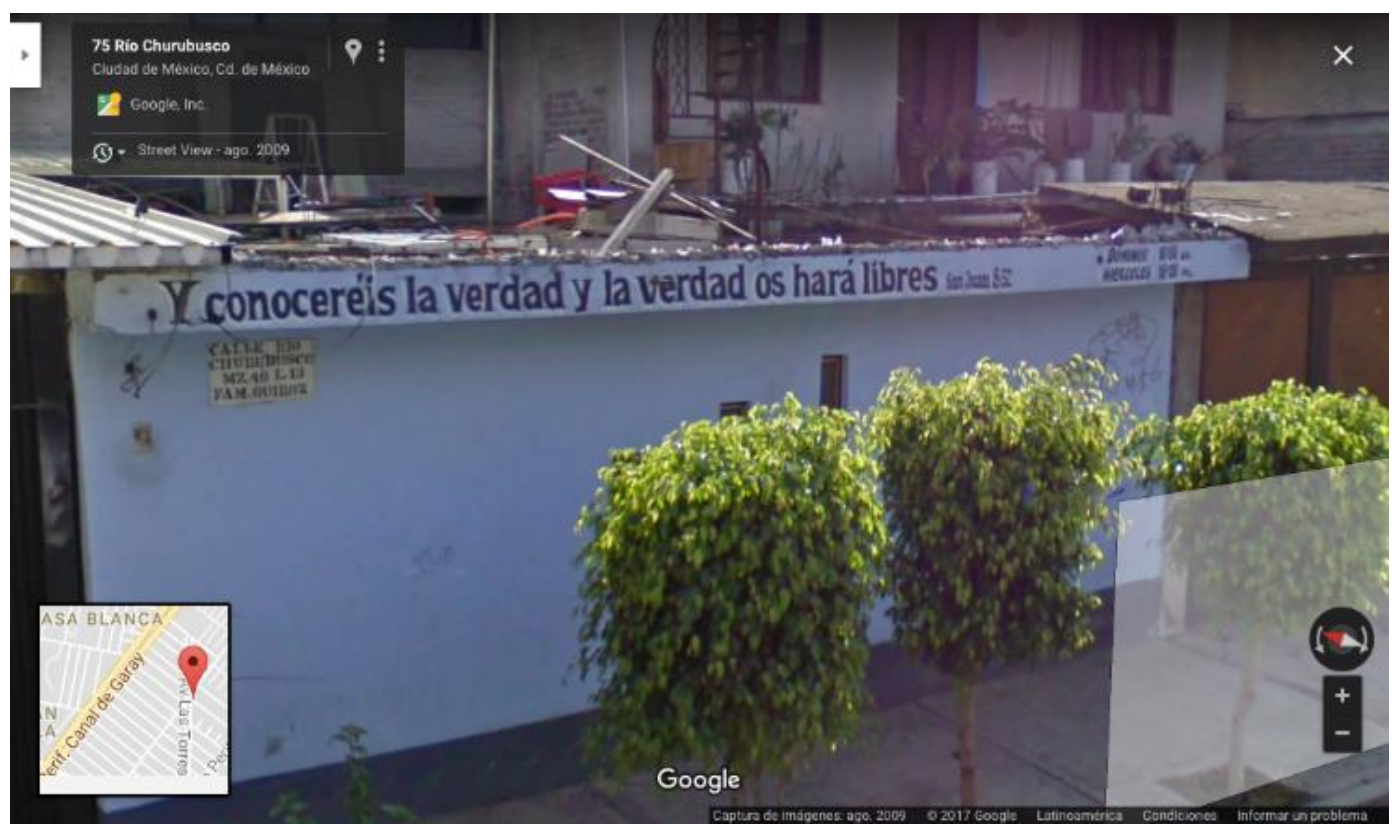

Imagen 12. Iglesia Bautista Cabsel Dios Reúne

Otro caso identificado es la existencia de paráfrasis de los versículos bíblicos, como se puede ver en la imagen 13, que es un mural de la Iglesia Centro de fe esperanza y amor, ubicada en la delegación Iztacalco. Ahí, las imágenes y el texto se conjugan, dándole más impacto visual al mensaje transmitido, ya que cada afirmación textual se ve reforzada por las imágenes que la acompañan. El mural transmite la idea de que en la vida existen dos caminos, uno que lleva a la condenación eterna y otro, que es creer en Jesús como medio para alcanzar la salvación por la eternidad. Los artistas que realizaron el mural reflejan la cosmovisión de

\footnotetext{
102 Juan 8:32: “y conoceréis la verdad, y la verdad os hará libres.”
} 
la iglesia en donde fue plasmado, al mostrarse en la vía pública la intención es causar impacto a todo aquél que lo contemple, de este modo, "la calle no es un campo de actuación limitado como el espacio interior, sino que es un ámbito abierto que permite la libre expresión de artistas y ciudadanos." 103

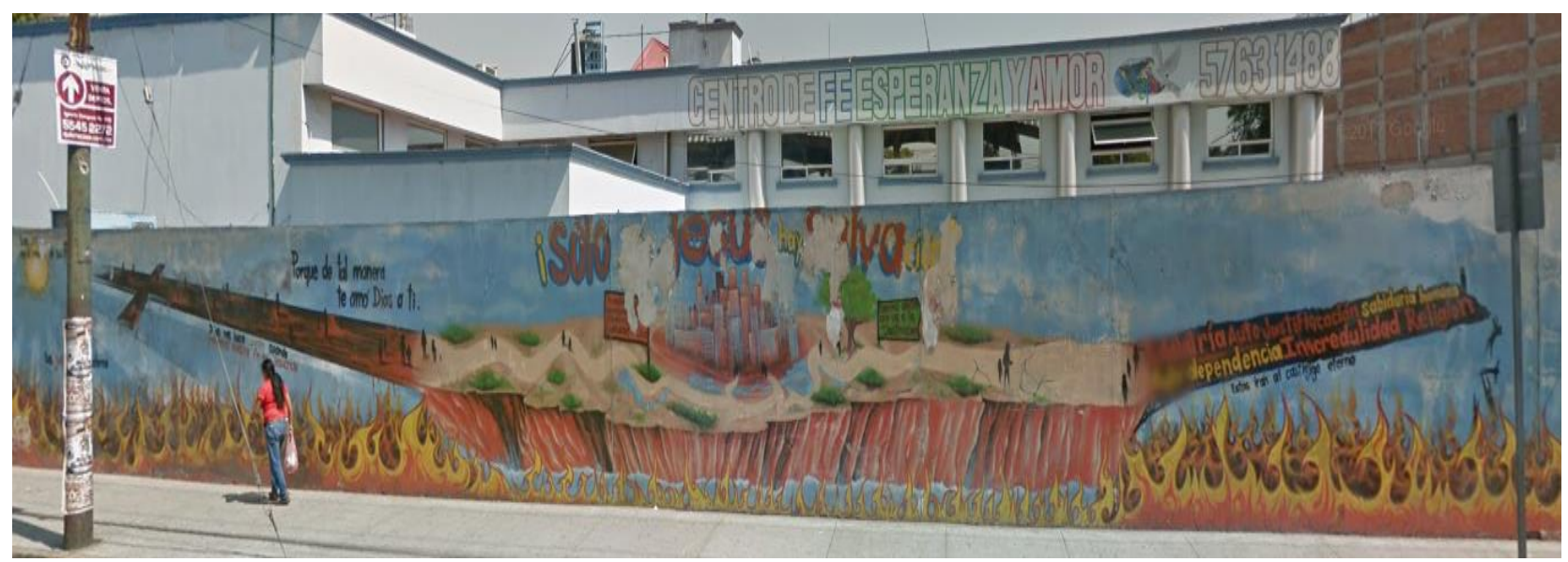

Imagen 13. Iglesia Centro de fe, esperanza y amor.

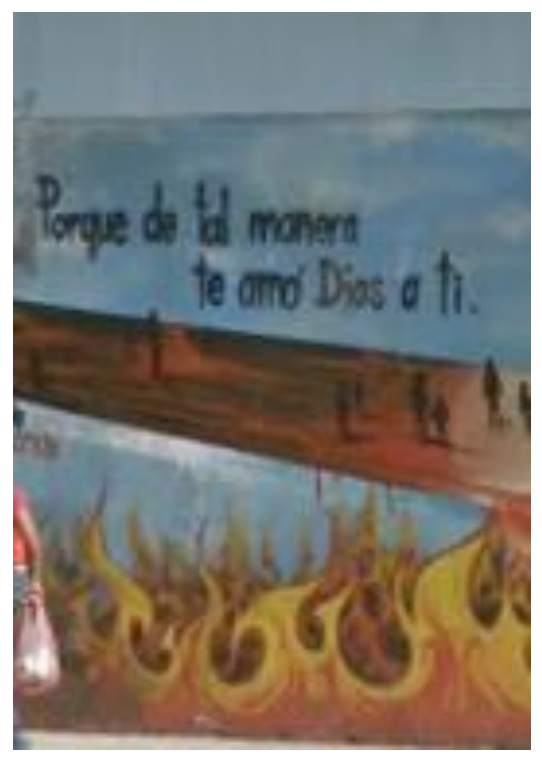

Imagen 14. Transformación del texto.

\footnotetext{
${ }^{103}$ María Luisa Grau Tello, "La pintura mural en el espacio urbano" en Revista de Andorra, núm. 8, 2009, p.
} 261. 
En la imagen 14 advertimos la transformación del versículo bíblico Juan 3:16, escrito originalmente en la tercera persona del singular: "Porque de tal manera amó Dios al mundo, que ha dado a su Hijo unigénito, para que todo aquel que en él cree, no se pierda, mas tenga vida eterna." Se muestra la transformación del versículo, ya que el texto está escrito en la segunda persona del singular: "Porque de tal manera te amó Dios a ti", por lo tanto es claro el cambio del mensaje de la pinta con respecto al original de la Biblia. Cabe mencionar que estos cambios y permanencias los analizo con respecto a la versión de la Biblia Reina-Valera, por ser la versión más reconocida y utilizada por los cristianos. Esta versión de la Biblia es producto del trabajo de Casiodoro de Reina que en 1569 realizó la traducción al español del Antiguo y Nuevo Testamento desde sus lenguas originales, arameo, hebreo y griego, respectivamente. Posteriormente en 1602 Cipriano Valera hizo una revisión del trabajo de Casiodoro, dando origen a la versión Reina-Valera.

Para comprender la manera en que es considerada esta versión de la Biblia en el contexto cristiano, quiero incluir las opiniones de diferentes Sociedades Bíblicas. La Sociedad Bíblica de España considera que la Versión Reina-Valera es la: "Biblia por excelencia' de las iglesias protestantes de habla hispana. Ha servido de inspiración a muchos creyentes en España y Latinoamérica, sobre todo en los dos últimos siglos”104 La Sociedad Bíblica Chilena la considera como una de las [versiones] más admiradas, tanto para eruditos protestantes como para aquellos que aunque no participan en esta interpretación de las Sagradas Escrituras, consideran la excelente calidad de la misma." ${ }^{105}$ En México la opinión

\footnotetext{
104 Tomado de https://www.sociedadbiblica.org/traducciones/reinavalera(consultado el 20 de julio de 2018).

105 Tomado de http://www.sbch.cl/sitio/2010/historia-de-la-primera-biblia-en-espanol-en-1569/(consultado el 25 de julio de 2018).
} 
es similar, en las conferencias de iglesias ${ }^{106}$ la versión más utilizada es la Reina-Valera, eso no quiere decir que sea la única versión disponible.

Retomando la exposición de los patrones que he encontrado en las pintas en la calle, también he identificado casos en los que, en la fachada, sólo se encuentra el nombre de la iglesia y algunos mensajes informando sobre eventos organizados por la misma. Como ejemplo incluyo la imagen 15 , en donde se puede observar la fachada de la iglesia Creyendo lo Imposible, ubicada en la delegación Cuauhtémoc. Es claro que sólo se encuentra el nombre de la iglesia y anuncios referentes a las actividades que se llevan a cabo en el recinto. Del lado derecho tenemos el anuncio de un seminario teológico y el del lado izquierdo el de un curso de verano para niños.

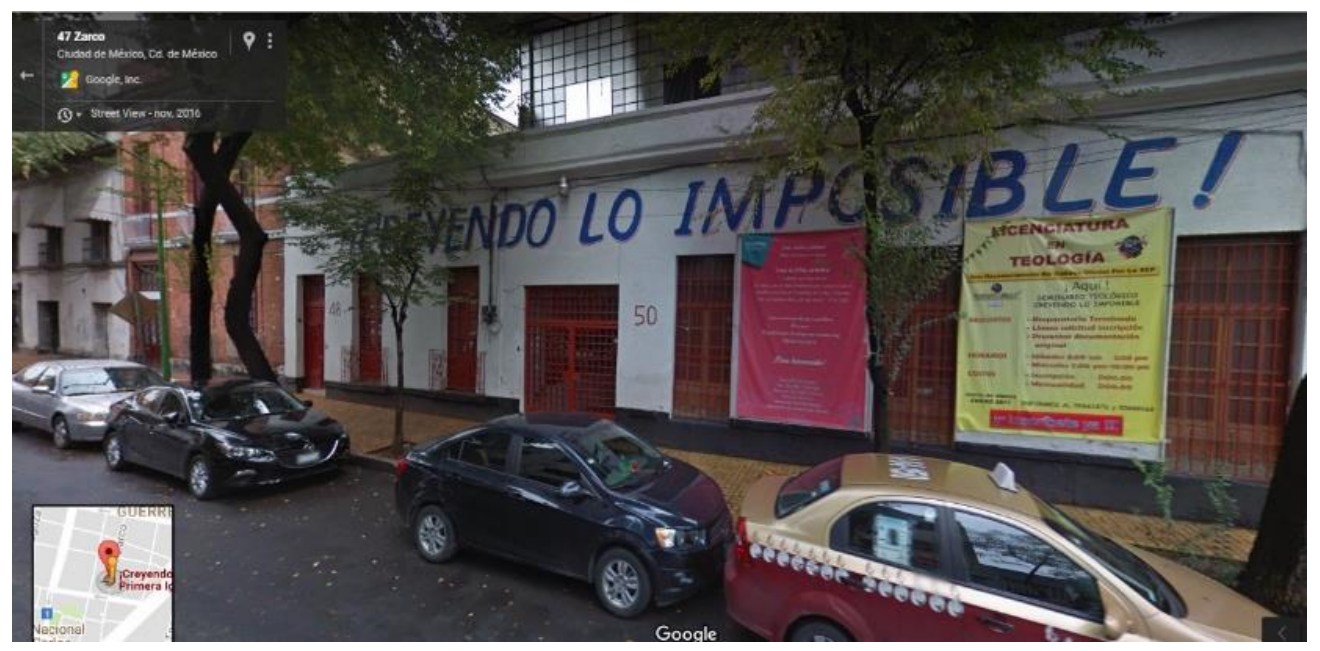

Imagen 15. Iglesia creyendo lo imposible.

\footnotetext{
${ }^{106}$ De manera presencial fui testigo de la utilización de esta versión en conferencias de la iglesia Amistad Cristiana y Monte Sion. La primera es pentecostal y se ubica en la delegación Coyoacán; la segunda es bautista y se encuentra en la delegación Iztapalapa.
} 
Haciendo un balance de lo que encontré en las pintas de las iglesias, hallé que los mensajes textuales aparecen con mayor frecuencia en la zona denominada MEDIA, además de que los pasajes bíblicos representados pertenecen al Antiguo Testamento. Cuando se combina el texto con imágenes, los mensajes son de salvación, invitando al arrepentimiento y destacando las bondades del cristianismo y la oportunidad de una nueva vida; sin embargo, cuando son de condenación, generalmente contienen algún elemento escatológico. En el caso de los mensajes en donde se presenta una paráfrasis de los versículos bíblicos, en la mayoría de los casos pertenecen a las iglesias ubicadas en la zona ALTA y los versículos elegidos son del Nuevo Testamento; en estos casos, la transformación muestra un cambio de la persona gramatical del mensaje, reflejando una clara apropiación del mensaje bíblico. Con respecto a los casos en que sólo tenemos el nombre de la iglesia, encontré que aparecen más en las iglesias de la zona BAJA, cuyos nombres están inspirados en el Antiguo Testamento. Con los datos obtenidos en el análisis, se puede determinar que los mensajes de salvación son predominantes, lo cual se puede explicar en razón de que una de las consignas del cristianismo es la propagación del evangelio, de modo que la invitación siempre abierta a la conversión concuerda con los datos obtenidos.

De esta forma, las imágenes en conjunto muestran que los cristianos buscan tener presencia en el espacio público, lo cual tiene un efecto en dos sentidos: los cristianos, al ver una pinta en la calle se sentirán representados en una especie de proyección de identidad. Por otro lado, a aquellos que no sean creyentes, tal vez no les cause impacto alguno, pero sí los confronta con elementos ajenos a ellos, porque las pintas se encuentran en espacios comunes. 
A pesar de que el $85 \%$ de los mexicanos son católicos, ${ }^{107}$ esto no impide que constantemente las iglesias cristianas encuentren maneras de socializar su fe. Si recordamos lo señalado en el capítulo 1, las iglesias se encuentran en la búsqueda constante de nuevos creyentes, por lo que adaptan el mensaje bíblico.

Una vez que identifiqué los patrones de las pintas en las iglesias mi segundo paso es comprender el papel que tienen las pintas en el espacio público. Aquí me ayudaron los conceptos de lugar antropológico y el de no lugar. El primero puede ser entendido como: "lugar de identidad, relacional e histórico"108; el segundo comprende: "tanto las instalaciones necesarias para la circulación acelerada de personas y bienes (vías rápidas, empalmes de rutas, aeropuertos) como los medios de transporte mismos o los grandes centros comerciales, o también los campos de tránsito prolongado donde se estacionan los refugiados del planeta." 109

Así, el lugar antropológico se encuentra relacionado con los espacios diseñados para que los individuos se relacionen entre sí; en cambio, los no lugares son espacios de tránsito, en donde los individuos pasan generalmente muy poco tiempo y en los que difícilmente interactúan entre sí. En este sentido las pintas se encuentran en los no lugares, puesto que están en la calles, se encuentran en un lugar de tránsito, cuando un enunciatario se encuentre frente a frente con los enunciados de la pinta, inmediatamente tendrá una relación fugaz con el enunciador. El enunciatario se apropia del enunciado representado en la pinta, se forma un

\footnotetext{
${ }^{107}$ Alberto Hernández Hernández, Cristina Gutiérrez Zúñiga y Renée de la Torre Castellanos (coords.), "Encuesta Nacional sobre Creencias y Prácticas Religiosas" realizada en 2016 por la Red de Investigadores del Fenómeno Religioso en México (RIFREM), disponible en http://www.rifrem.mx/?publicacion=encuestanacional-en-mexico-sobre-creencias-y-practicas-religiosas (consultado el 4 de febrero de 2018).

${ }_{108}$ Marc Augé, Los no lugares. Espacios de anonimato. Una antropología de la sobremodernidad, Barcelona, Gedisa, 2000, p. 44.

${ }^{109}$ Ibíd., p. 22.
} 
juicio sobre la Iglesia, el cual puede ser de rechazo, afinidad o indiferencia, todo dependerá de la cosmovisión del enunciatario, pero también del carácter del enunciado representado en la pinta.

Para ejemplificar la forma en que entiendo estos conceptos y mostrar cómo pueden ser aplicados en mi investigación quiero detallar la siguiente situación: La pinta de la imagen 16 contiene una frase extraída del Salmo $23,{ }^{110}$ aunque se cita la referencia bíblica con la abreviación del capítulo, contiene un error ortográfico al faltarle la h al nombre de Jehová. Esta pinta se encuentra ubicada en el eje 5 en la colonia Renovación de la Delegación Iztapalapa. Es decir, se encuentra en un no lugar porque está en una vía rápida, la cual no permite que los automovilistas ${ }^{111}$ se relacionen ni entablen conversaciones, ya que es un lugar de tránsito. Sin embargo, en las ocasiones en que el tráfico satura esta avenida, los conductores se ven obligados a transitar con poca o nula velocidad, una situación que los obliga a poner atención en los detalles del espacio que los rodea; en el momento en que se enfoquen en la pinta, criticándola, apreciándola positivamente o simplemente leyéndola, este no lugar se convierte en un lugar antropológico porque ya tuvo lugar un encuentro entre el automovilista y el enunciador de la pinta. De este modo, la pinta produjo un lugar antropológico porque para el automovilista tiene un significado particular y se produjo un encuentro entre él y un mensaje que lo interpela, aunque lo pueda dejar indiferente.

\footnotetext{
110 Salmo 23:1 "Jehová es mi pastor; nada me faltará”

111 Aunque para ejemplificar utilicé el caso de los automovilistas, considero que la misma dinámica es válida para los peatones que pasan por esta avenida.
} 


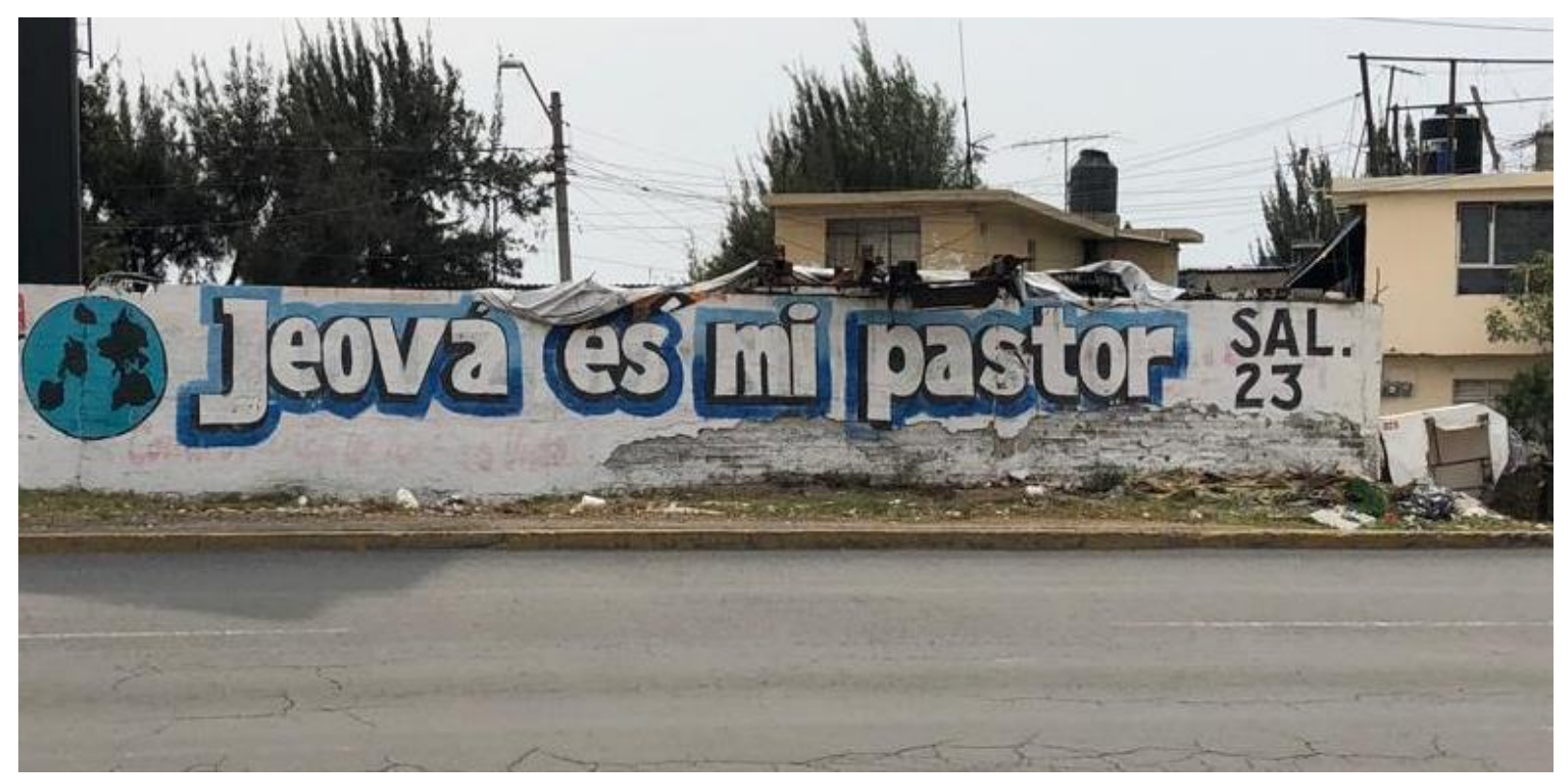

Imagen 16. Pinta ubicada en el eje 5 de la Delegación Iztapalapa

Por ejemplo, un mensaje de salvación, en el momento adecuado puede sumar nuevos creyentes; un enunciado de condenación, en un mal momento puede alejar al enunciatario, en realidad las posibilidades de las relaciones entre el enunciado y el enunciatario son casi infinitas. Es interesante observar cómo se establecen relaciones privadas en los no lugares y también identificar que un mismo enunciado puede provocar diversas reacciones.

Es así que las relaciones intermitentes y en cierto modo azarosas, entre enunciatarios y enunciados suceden en los no lugares: "en los espacios en donde se considera que los individuos no interactúan sino con los textos sin otros enunciadores que las personas morales' o las instituciones...cuya presencia se adivina vagamente $\mathrm{o}$ se afirma más explícitamente...detrás de los mandatos, los consejos, los comentarios, los 'mensajes' transmitidos por innumerables soportes' (carteles, pantallas, afiches) que forman parte integrante del paisaje contemporáneo." ${ }^{112}$ En cierto sentido, las pintas son dialogantes, por

${ }^{112}$ Marc Augé, op. cit., p. 53. 
los enunciados que contiene, mismos que son susceptibles de conectar con un enunciatario y transmitir su contenido. En este contexto, las pintas en las fachadas o cercanía de las iglesias representan la oportunidad de exteriorizar y mostrar a los demás lo que representa el cristianismo. Los enunciados representados están en la búsqueda constante y pasiva de algún enunciatario al cual poder transmitir su mensaje. A continuación me referiré a otro movimiento del lenguaje religioso, me refiero a los Tratados Chick.

\subsection{Tratados Chick}

Los Tratados Chick son historietas breves que tratan un tema en particular, su finalidad es dar a conocer al lector distintos mensajes bíblicos. Estos cuadernillos fueron realizados por el caricaturista estadounidense, Jack T. Chick, conocido mundialmente por su obra: "Jack Chick ha escrito y publicado cientos de tratados evangelísticos ilustrados en casi 100 idiomas. Inclusive se exhiben algunas copias de los tratados Chick en el Instituto Smithsoniano, como parte integral de la cultura de los Estados Unidos. Cientos de millones de copias han sido leídas a nivel mundial." 113

A pesar de que este autor murió en octubre del 2016, la editorial Chick Publications sigue publicando su obra hasta la fecha. Es importante señalar que ellos se denominan evangelistas, un término que implica una unidad dentro de la diversidad cristiana, tal como lo expliqué en el capítulo 1. Existe un total de 170 tratados que se traducen de manera conjunta en más de cien idiomas diferentes, entre ellos el chino, el francés, el noruego y el español, pero el idioma original de los tratados es el inglés. En México hay dos maneras de

\footnotetext{
113 Tomado de http://www.chick.com/es/information/authors/chick.asp (consultado el 4 de noviembre de 2017).
} 
conseguir estos tratados, de manera física en la librería cristiana Maranatha, ${ }^{114} \mathrm{y}$ de manera digital y gratuita en la página oficial de la editorial. ${ }^{115}$

Elegí estas historietas porque combinan elementos gráficos y escritos, lo que les da una característica de versatilidad muy importante. Además, al tratar de recrear situaciones de la vida cotidiana con temas específicos de la sociedad, se convierten en una especie de guía para el creyente, así como en una invitación siempre abierta para el no creyente. A los 170 tratados los clasifiqué en dos rubros. Al primero lo llamé "Nociones básicas de cristianismo," en éste coloqué historietas que invitan al no creyente a conocer el cristianismo y guían a los recién convertidos. ${ }^{116} \mathrm{Al}$ segundo rubro le puse el nombre de "Vida cristiana," en él entran las historietas pensadas para profundizar en los conocimientos bíblicos del creyente, así como exponer la postura cristiana con respecto a diferentes temas sociales, como el alcoholismo, y la inseguridad, entre otros. Cabe señalar que está clasificación la determiné debido a que no quise seguir el modelo original de la editorial Chick Publications, porque ellos clasifican los tratados en 46 rubros diferentes (enojo, codicia, pandillas ocultismo, perdón, niños, por mencionar algunos); pero para mis fines es mejor englobarlos en las dos categorías que propongo.

La imagen 17 es un ejemplo de historieta que entra en el primer rubro, donde se narra la historia de un niño que vive en la calle que encuentra consuelo en el conocimiento de que “Jesús lo ama.” Este saber, dentro de la cosmovisión cristiana es uno de los pilares de la fe.

\footnotetext{
${ }^{114}$ En la Ciudad de México cuenta con cinco sucursales, localizadas en: Miguel Ángel de Quevedo, Satélite, Lindavista, Iztapalapa y Bolívar.

${ }^{115}$ Sitio oficial de la editorial: http://www.chick.com/es/

116 Son las personas que acaban de adoptar la fe cristiana.
} 



Imagen 17: "Alguien me ama"

Para ejemplificar el segundo rubro, en la imagen 18 se puede ver el fragmento de una historieta titulada "El bravucón", en la que se puede observar una crítica al alcoholismo, además de ser una historia de redención y superación de las adicciones por medio del cristianismo. Específicamente el relato muestra la vida de un alcohólico que después de experimentar una vivencia cercana a la muerte visualiza el infierno, por lo que trata de hacer todo lo posible por alejarse de ese destino, y en ese momento, cuando acude a una iglesia cristiana, se convierte al cristianismo.
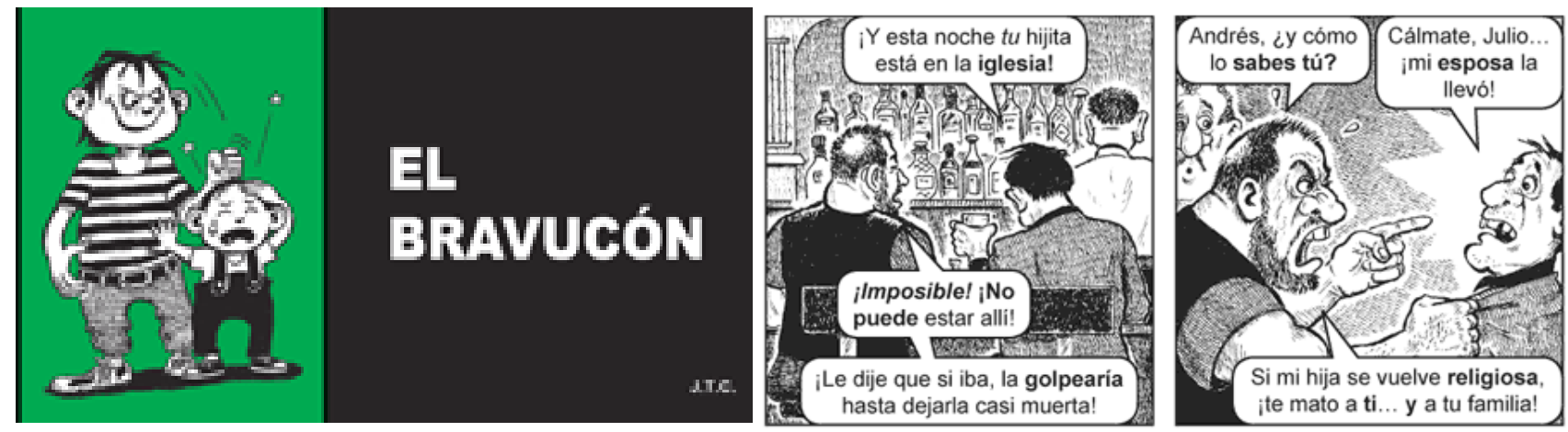

Imagen 18: "El bravucón”

En estas historietas me encuentro con enunciados como el del Tratado titulado:

“Todo depende de ti!” (Imagen 19), el cual cuenta la historia de un personaje llamado Ana, quién en una primera instancia se muestra desagradecida por el estilo de vida que le dan sus padres, posteriormente su abuelo predica sobre el cristianismo y las consecuencias de seguir 
el pecado, al final ella se convence y se convierte en cristiana. De toda la historieta me interesa destacar el siguiente enunciado: "En ese momento sucedió lo más maravilloso:

¡Ella nació de nuevo?” (Imagen 20) ${ }^{117}$

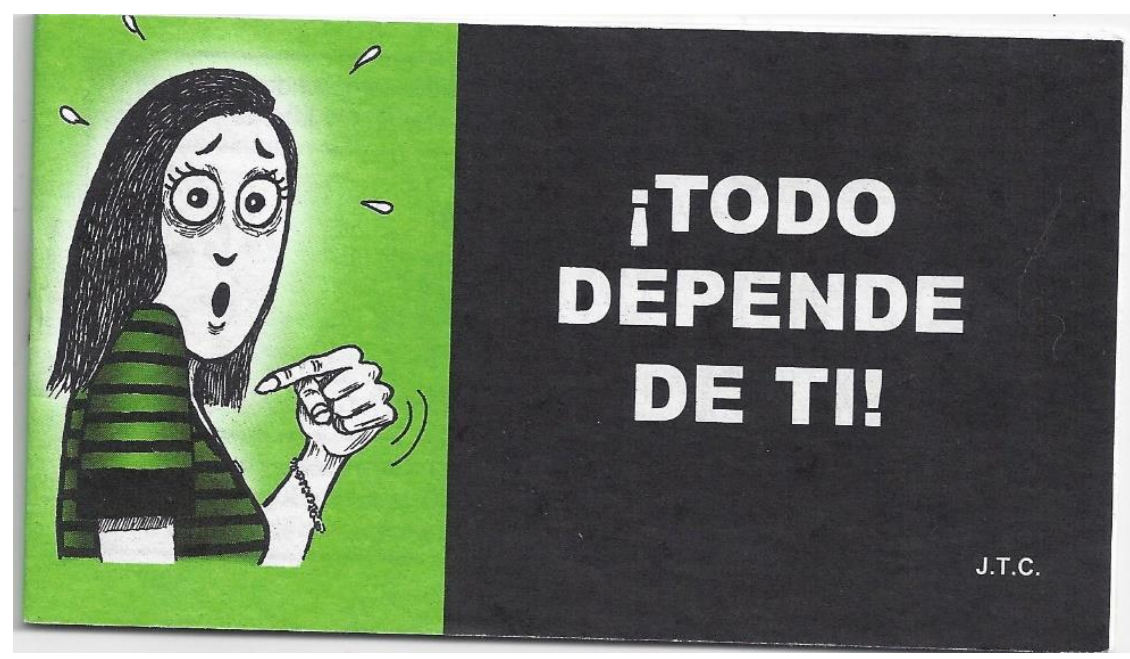

Imagen 19. Portada “¡Todo depende de ti!”

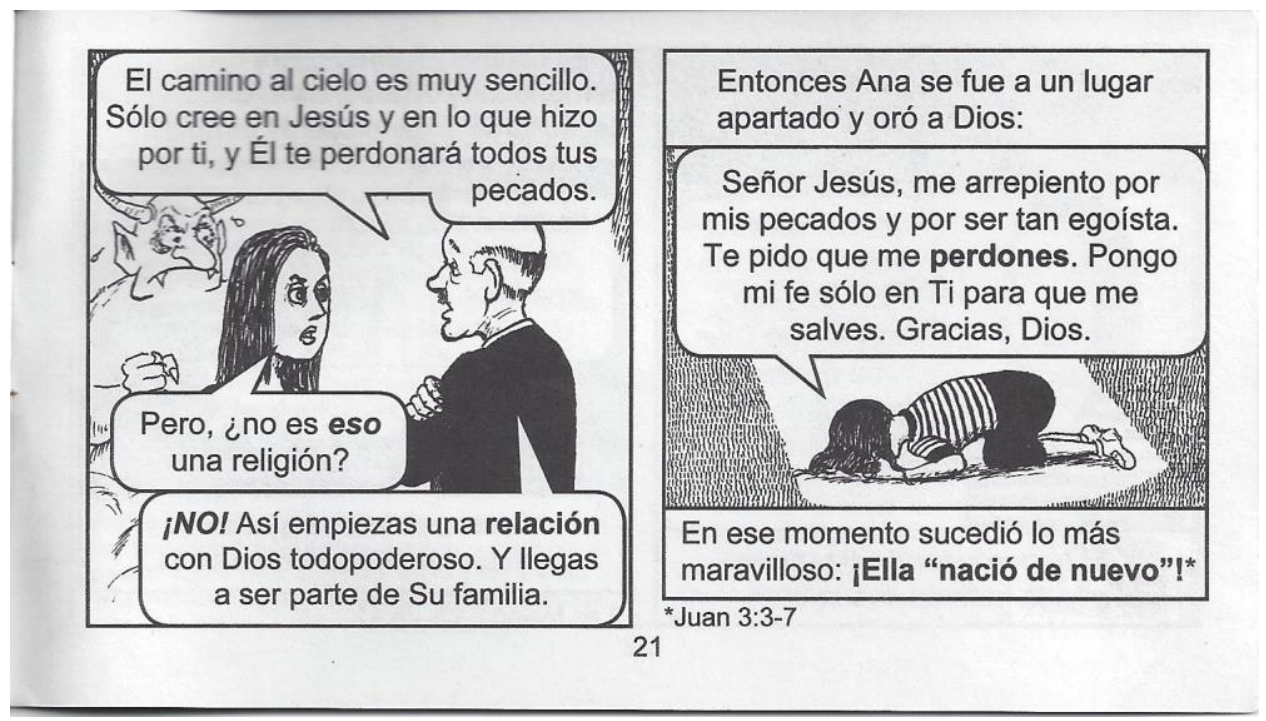

Imagen 20. Página 21 en donde se puede observar el enunciado referido.

${ }^{117}$ Las letras en negritas aparecen así en la historieta. 
En la historieta es posible identificar la apropiación y síntesis del mensaje bíblico representado en los versículos del 3 al 7 del capítulo 3 del libro de Juan, ${ }^{118}$ referente a la lección de nacer de nuevo, la cual se refiere a alcanzar la salvación aceptando a Jesús como salvador, naciendo a una nueva vida, y que no se refleja aquí de manera textual, sino que se la recrea en una escena enunciativa que usa elementos gráficos y texto. Para entender bien la situación del personaje, la historieta invita al lector a buscar el pasaje bíblico mencionado. Esto conforma una función metalingüística, puesto que "remite el signo al código del cual extrae su significación"119: "nacer de nuevo" sería el signo y el código sería la Biblia.

De manera general los Tratados, independientemente de mi clasificación, van instruyendo al lector en los diferentes conceptos del cristianismo, cada una de las historias y vivencias referidas en las páginas de las historietas tienen el objetivo de lograr una audiencia cada vez más preparada. El número de conceptos y enseñanzas de cada historieta es muy diversa, por ejemplo en la imagen 22, en una página del tratado titulado “¿El porvenir?

\footnotetext{
${ }^{118}$ Juan 3:3-7 "3:3 Respondió Jesús y le dijo: De cierto, de cierto te digo, que el que no naciere de nuevo, no puede ver el reino de Dios.

3:4 Nicodemo le dijo: ¿Cómo puede un hombre nacer siendo viejo? ¿Puede acaso entrar por segunda vez en el vientre de su madre, y nacer?

3:5 Respondió Jesús: De cierto, de cierto te digo, que el que no naciere de agua y del Espíritu, no puede entrar en el reino de Dios.

3:6 Lo que es nacido de la carne, carne es; y lo que es nacido del Espíritu, espíritu es.

3:7 No te maravilles de que te dije: Os es necesario nacer de nuevo."

${ }^{119}$ Pierre Guiraud, La semiología, México, Siglo XXI, 1972, p. 15.
} 
(Véase portada en la imagen 21) tenemos la presencia de tres conceptos, la Iglesia como esposa de Jesús, ${ }^{120}$ las Bodas del Cordero ${ }^{121}$ y el Arrebatamiento. ${ }^{122}$

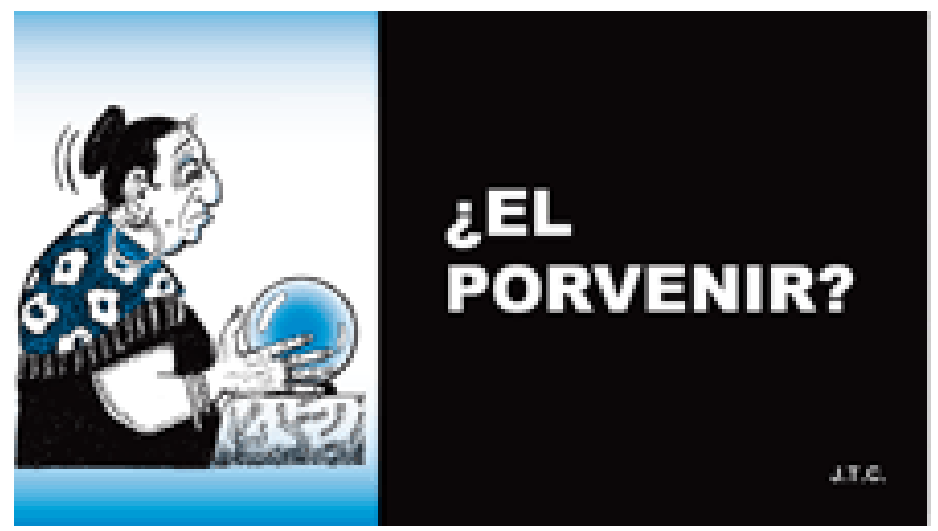

Imagen 21. Portada “¿El porvenir?
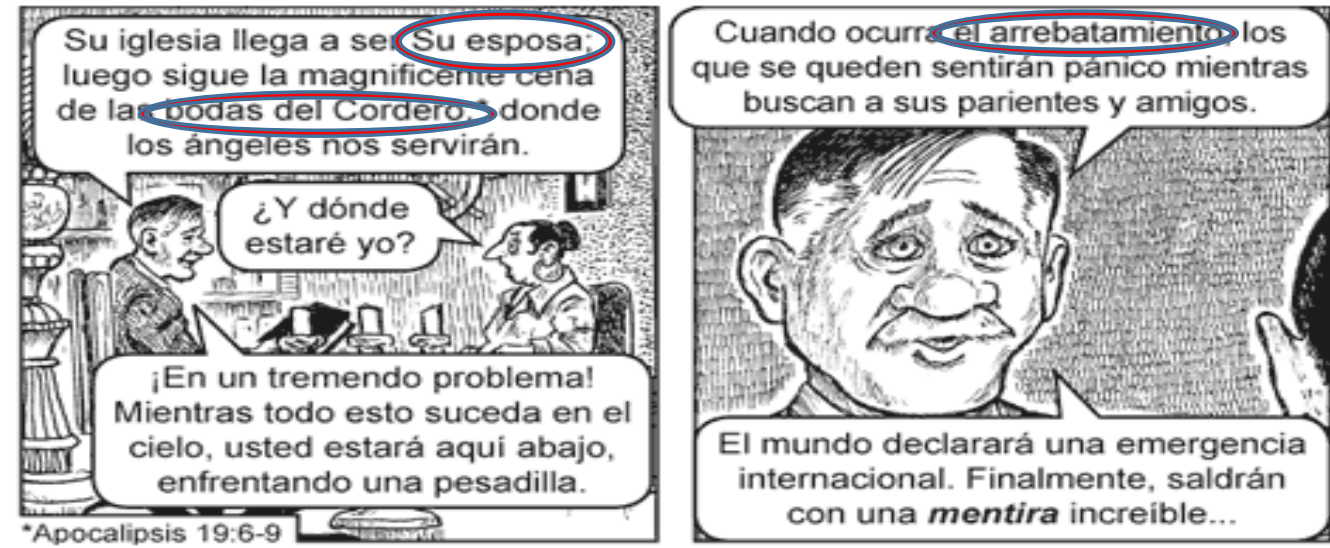

Imagen 22. Página 13, encerradas en un círculo se encuentran marcadas las enseñanzas del cristianismo

\footnotetext{
${ }^{120}$ Se refiere a la idea de que la iglesia, entendida como el conjunto de todos los creyentes es la esposa de Jesús.

${ }^{121}$ Hace referencia a la unión de Jesús y su iglesia en la segunda venida de Cristo, Apocalipsis 19:7-9:

"7Gocémonos y alegrémonos y démosle gloria; porque han llegado las bodas del Cordero, y su esposa se ha preparado.8Y a ella se le ha concedido que se vista de lino fino, limpio y resplandeciente; porque el lino fino es las acciones justas de los santos.9Y el ángel me dijo: Escribe: Bienaventurados los que son llamados a la cena de las bodas del Cordero. Y me dijo: Estas son palabras verdaderas de Dios.

${ }^{122}$ Esta enseñanza remite a la creencia de que Jesús se llevará al cielo en un abrir y cerrar de ojos a sus seguidores. 1ra de Tesalonicenses 4:16-17: "16 Porque el Señor mismo con voz de mando, con voz de arcángel, y con trompeta de Dios, descenderá del cielo; y los muertos en Cristo resucitarán primero.

17 Luego nosotros los que vivimos, los que hayamos quedado, seremos arrebatados juntamente con ellos en las nubes para recibir al Señor en el aire, y así estaremos siempre con el Señor.”
} 
En los Tratados Chick los mensajes bíblicos traspasan el espacio tradicional de la Biblia y la Iglesia, y su formato permite al creyente conocer de otra manera las enseñanzas que conlleva su fe, además de que los no creyentes se confrontan con otra cosmovisión sin tener que recurrir a la Biblia o a un templo. Sin duda, las historietas forman parte de la versatilidad que caracteriza al cristianismo en el momento de mostrar y socializar su fe, y es un ejemplo más de la presencia del texto bíblico en formatos que van más allá de los tradicionales. 


\subsection{Canciones (alabanzas)}

El último elemento de mi corpus son las alabanzas, que se pueden entender como una canción que no tiene como objetivo la recreación sino la alabanza de Dios; en este sentido, las canciones no se encuentran dirigidas o dedicadas a la congregación, sino que son cánticos dirigidos específicamente a Dios. Al hablar de las alabanzas, no se puede dejar de mencionar del góspel, un género musical que nació en las iglesias protestantes de los Estados Unidos de América, que nació como respuesta a la opresión que sufrían los afroamericanos en ese país:

La música góspel es un fenómeno musical y social del siglo XX-uno de los varios géneros de música sacra afro-americana desarrollada durante los años 1920 y 1930, cuando músicos combinaron elementos de música blues y jazz con cantos religiosos- que refleja las condiciones sociales devastadoras que los afroamericanos han experimentado en sus vidas, desde la opresión social y política hasta la desmoralización cultural y la segregación racial. ${ }^{123}$

Como herederas del góspel las alabanzas reflejan ese deseo de consuelo ante las adversidades de la vida, en cuyas letras es posible encontrar enunciados que muestran las hazañas de Dios, las acciones de obediencia, triunfo, fracaso y esfuerzo de personajes bíblicos, así como, elementos aleccionadores sobre la doctrina cristiana. He incluido en el corpus las canciones porque en sus letras es notoria la apropiación del texto bíblico. En primer lugar, hay que señalar que en las canciones, la enunciación se lleva a cabo por parte de los intérpretes. Componer la letra de una canción representa todo un ejercicio de apropiación de los mensajes de la Biblia, ya que las letras, como ya mencioné, suelen estar

\footnotetext{
${ }^{123}$ Alina Pele, Las distribuciones vocales en coros Góspel: percepción de coristas y oyentes, (tesis doctoral) en

https://riunet.upv.es/bitstream/handle/10251/30775/Tesis\%20completa\%20Alina\%20Leucian\%20Pele\%20co

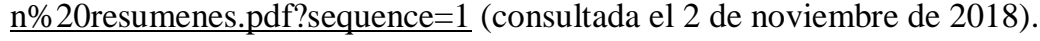


llenas de alegorías, enseñanzas y vivencias, que tienen como objetivo sintetizar experiencias que puede estar viviendo algún creyente.

Este tipo de canciones conforman todo un género musical que tiene a muchos intérpretes y grupos, incluso conocidos a nivel internacional, como por ejemplo, Marcela Gándara, que es una cantante y compositora originaria de Chihuahua. Otro es Marcos Witt, originario de San Antonio, Texas; también está la banda australiana de música cristiana, Hillsong Worship, Delirious, que es una banda británica, entre muchos otros. La accesibilidad a este tipo de canciones es relativamente fácil, puesto que se pueden encontrar en tiendas digitales o establecimientos dedicados a la venta de música. A través del tiempo, las alabanzas han pasado por diferentes formatos de grabación como el cassette (véase imagen 23), discos compactos (véase imagen 24) y formatos de plataformas digitales (véase imagen 25).
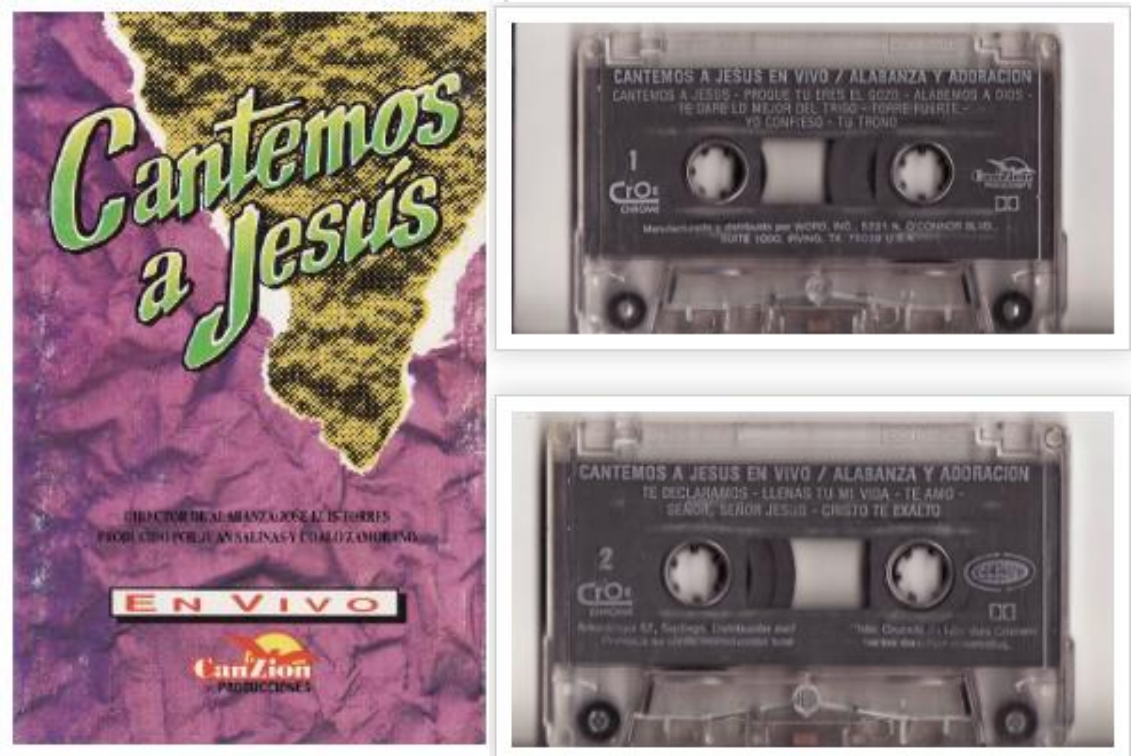

Imagen 23. Portada y cassette de José Luis Torres, Cantemos a Jesús (1992) 

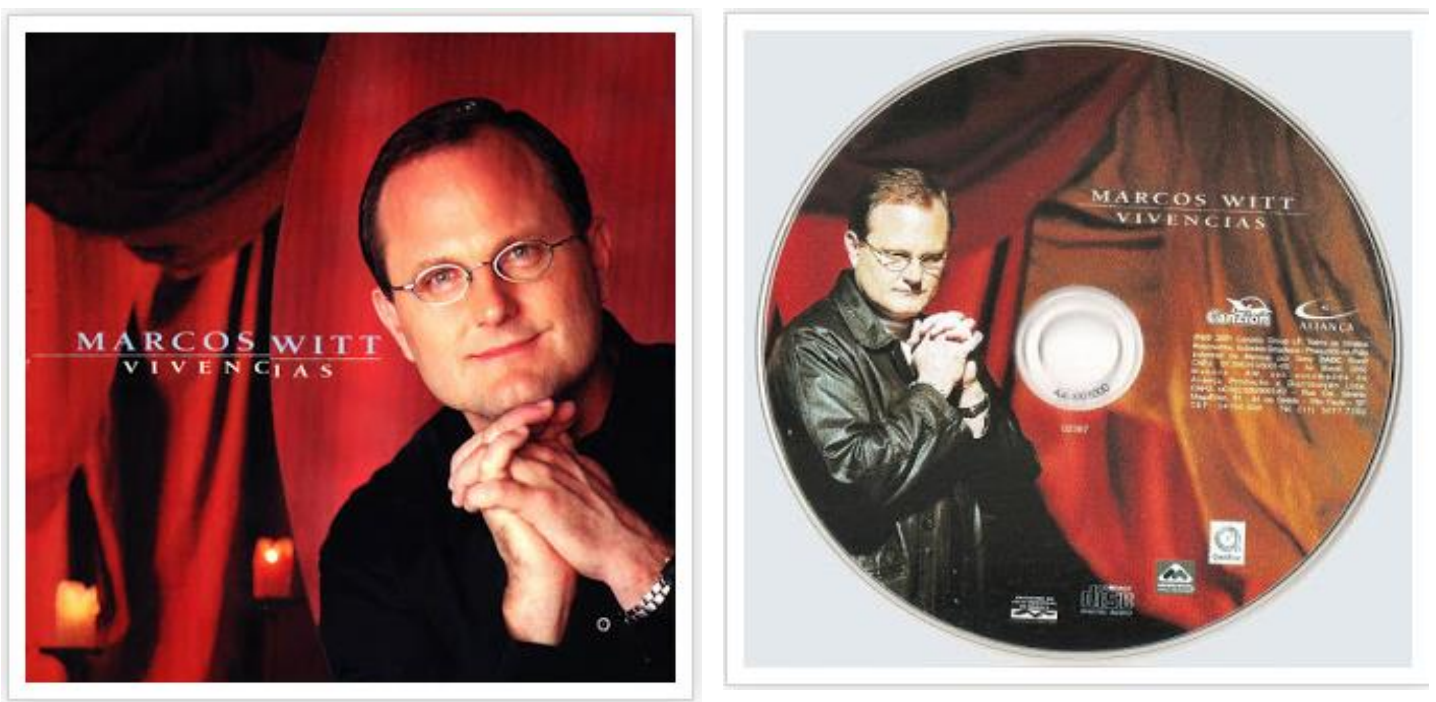

Imagen 24. Portada y disco compacto de Marcos Witt, Vivencias, 2001

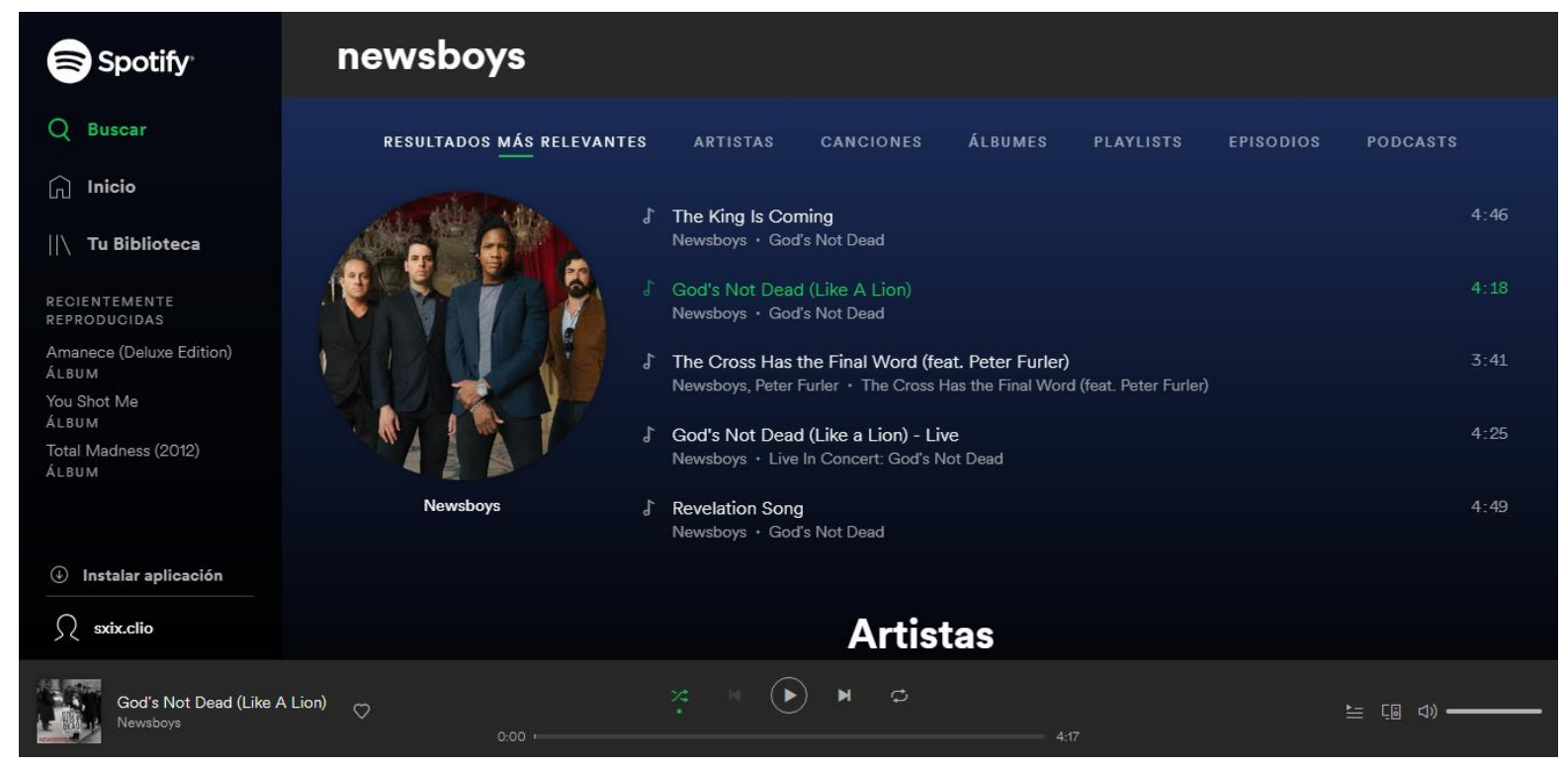

Imagen 25. Plataforma digital, Spotify Newsboys, God's not dead, 2011

Para el corpus de las canciones, elegí 15, con el fin de lograr una muestra significativa, y tomé en cuenta tres factores. En primera instancia, la temporalidad, es decir el año en que fue interpretada la canción, con lo cual buscó determinar si existe una evolución en cuanto a los elementos bíblicos presentes en las canciones. El segundo criterio es el lugar de origen, que me permitirá establecer patrones de las acciones de los creyentes en diversas 
latitudes. Por último, el tipo de grabación, es decir si las canciones fueron interpretadas en estudio o en vivo, me permite identificar la dinámica al momento de interpretar una alabanza.

A continuación presento una tabla con el corpus de las canciones que elegí:

\begin{tabular}{|c|c|c|c|c|c|c|}
\hline Canción & Cantante & Álbum & Año & $\begin{array}{l}\text { Tipo de } \\
\text { grabación }\end{array}$ & Duración & $\begin{array}{l}\text { Lugar de } \\
\text { grabación }\end{array}$ \\
\hline $\begin{array}{l}\text { 1. Santo y } \\
\text { poderoso }\end{array}$ & $\begin{array}{l}\text { Marco } \\
\text { Barrientos }\end{array}$ & $\begin{array}{l}\text { Levántate y } \\
\text { resplandece }\end{array}$ & 2016 & $\begin{array}{l}\text { Medley }^{124} \\
\text { (en vivo) }\end{array}$ & $11: 19$ & $\begin{array}{l}\text { Arlington, } \\
\text { Texas }\end{array}$ \\
\hline $\begin{array}{l}\text { 2. El camino } \\
\text { del señor }\end{array}$ & $\begin{array}{l}\text { Marco } \\
\text { Barrientos }\end{array}$ & $\begin{array}{l}\text { Levántate y } \\
\text { resplandece }\end{array}$ & 2016 & $\begin{array}{l}\text { Medley (en } \\
\text { vivo) }\end{array}$ & $5: 47$ & $\begin{array}{l}\text { Arlington, } \\
\text { Texas }\end{array}$ \\
\hline $\begin{array}{l}\text { 3. Danzaré, } \\
\text { Cantaré }\end{array}$ & Marcos Witt & $\begin{array}{l}\text { Sana Nuestra } \\
\text { tierra }\end{array}$ & 2001 & En vivo & $7: 52$ & Houston, Texas \\
\hline $\begin{array}{l}\text { 4. Hasta } \\
\text { acabar mi } \\
\text { viaje }\end{array}$ & $\begin{array}{l}\text { Jesús Adrián } \\
\text { Romero con } \\
\text { colaboración } \\
\text { de Rocío } \\
\text { Cereceres }\end{array}$ & $\begin{array}{l}\text { Soplando } \\
\text { vida }\end{array}$ & 2012 & En vivo & $4: 20$ & $\begin{array}{l}\underline{\text { San }} \\
\underline{\text { Diego }}, \underline{\text { Tornillo }} \\
\text { y } \underline{\text { Phoenix. }}\end{array}$ \\
\hline $\begin{array}{l}\text { 5. Dame este } \\
\text { monte }\end{array}$ & $\begin{array}{l}\text { Daniel } \\
\text { Santoy con } \\
\text { colaboración } \\
\text { de Jesús } \\
\text { Adrián } \\
\text { Romero }\end{array}$ & $\begin{array}{l}\text { En otras } \\
\text { palabras }\end{array}$ & 2006 & En vivo & $3: 39$ & $\begin{array}{l}\text { Phoenix, } \\
\text { Arizona }\end{array}$ \\
\hline $\begin{array}{l}\text { 6. La niña de } \\
\text { tus ojos }\end{array}$ & $\begin{array}{l}\text { Daniel } \\
\text { Calveti }\end{array}$ & Vivo para ti & 2005 & En vivo & $3: 31$ & Puerto Rico \\
\hline 7. Hosanna & $\begin{array}{l}\text { Marcela } \\
\text { Gándara }\end{array}$ & $\begin{array}{l}\text { Hillsong } \\
\text { Global } \\
\text { project }\end{array}$ & 2012 & En vivo & $5: 44$ & Australia \\
\hline 8. Yeshúa & Marcos Witt & Proyecto AA & 1991 & En estudio & $3: 12$ & $\begin{array}{l}\text { Monterrey, } \\
\text { México }\end{array}$ \\
\hline $\begin{array}{l}\text { 9. Abba } \\
\text { Padre }\end{array}$ & $\begin{array}{l}\text { Miel San } \\
\text { Marcos con } \\
\text { colaboración }\end{array}$ & $\begin{array}{l}\text { Pentecostés } \\
\text { (en vivo) }\end{array}$ & 2017 & En vivo & $4: 52$ & $\begin{array}{l}\text { Madison } \\
\text { Square Garden, } \\
\text { Nueva York }\end{array}$ \\
\hline
\end{tabular}

124 Tipo de interpretación de larga duración que une varias piezas musicales. 


\begin{tabular}{|l|l|l|l|l|l|l|}
\hline & \multicolumn{2}{|l|}{$\begin{array}{l}\text { de Marcela } \\
\text { Gándara }\end{array}$} & & & & \\
\hline $\begin{array}{l}\text { 10. Yeshúa } \\
\text { Ha'mashiach }\end{array}$ & $\begin{array}{l}\text { Juan Carlos } \\
\text { Alvarado }\end{array}$ & Fiesta & 2004 & En vivo & $5: 03$ & Guatemala \\
\hline $\begin{array}{l}\text { 11. Me } \\
\text { gozaré }\end{array}$ & $\begin{array}{l}\text { Miguel } \\
\text { Cassina }\end{array}$ & $\begin{array}{l}\text { Dame más de } \\
\text { ti }\end{array}$ & 1989 & En estudio & $5: 02$ & México \\
\hline $\begin{array}{l}\text { 12. Roca } \\
\text { eterna }\end{array}$ & Marcos Witt & Te exaltamos & 1992 & En estudio & $2: 49$ & México \\
\hline $\begin{array}{l}\text { 13. León de } \\
\text { Judá }\end{array}$ & Inspiración & $\begin{array}{l}\text { Conquistando } \\
\text { a las naciones }\end{array}$ & 1997 & En vivo & $5: 16$ & $\begin{array}{l}\text { Downey, } \\
\text { California }\end{array}$ \\
\hline $\begin{array}{l}\text { 14. Al } \\
\text { cordero } \\
\text { inmolado }\end{array}$ & New Wine & $\begin{array}{l}\text { Adoración en } \\
\text { vivo }\end{array}$ & 2014 & En vivo & $10: 20$ & Miami, Florida \\
\hline $\begin{array}{l}\text { 15. El } \\
\text { poderoso de } \\
\text { Israel }\end{array}$ & $\begin{array}{l}\text { Juan Carlos } \\
\text { Alvarado }\end{array}$ & Fuego & 2006 & En vivo & $1: 19$ & Guatemala \\
\hline
\end{tabular}

Tabla 1. Corpus de canciones

Encontré tres patrones en las canciones que elegí, el primero es el cambio de persona gramatical con respecto al que aparece en la Biblia. Cabe mencionar que este cambio era frecuentemente en las interpretaciones en vivo. Un ejemplo es la canción, interpretada en vivo, "Santo y poderoso/ El Señor está en este lugar" del intérprete Marco Barrientos, en donde aparece una apropiación del versículo bíblico: Lucas 10:19 "He aquí os doy potestad de hollar serpientes y escorpiones, y sobre toda fuerza del enemigo, y nada os dañará." En la Biblia, el enunciado se encuentra en segunda persona del plural, pero en la canción, minuto 9:18-9:45, el enunciado se reformula en la primera persona del singular, apropiándose del sentido de la frase: “yo piso sobre serpientes y escorpiones, en el nombre de Jesús... y nada me dañará." Considero que la propia dinámica del concierto permite interactuar con el 
público y hacer apropiaciones de las enseñanzas contenidas en las alabanzas. Otras canciones en las que este fenómeno pasa son: "El camino del señor" y "Danzaré y Cantaré"125

El segundo patrón es la aparición constante de símbolos ${ }^{126}$ que forman parte de la cosmovisión cristiana. En el paso de la escritura de la Biblia a otro tipo de enunciación existen aspectos que se mantienen y otros que no. Lo que cambia siempre busca atraer al enunciatario, es decir al que recibe el enunciado. Estos cambios parecen no alterar o trastocar una base común de los mensajes bíblicos, situaciones o personajes que siguen siendo reconocidos como autoridad. Por ejemplo de la canción 11 a la 15 se encuentran los siguientes símbolos:

\begin{tabular}{|l|l|}
\hline Símbolo & Interpretación \\
\hline León de Judá & Jesús \\
\hline Cordero inmolado & Jesús \\
\hline Poderoso de Israel & Jehová \\
\hline Roca eterna & Jesús \\
\hline Bodas del cordero & $\begin{array}{l}\text { Representa la segunda venida de Jesús } \\
\text { encontrándose con su Iglesia (conjunto de } \\
\text { creyentes) }\end{array}$ \\
\hline Esposa vestida de lino fino & Iglesia \\
\hline
\end{tabular}

Tabla 2. Símbolos encontrados en canciones

El tercer patrón que se muestra en las canciones de la siete a la diez es la utilización de la transliteración de palabras de origen hebreo, específicamente las palabras Hosanna

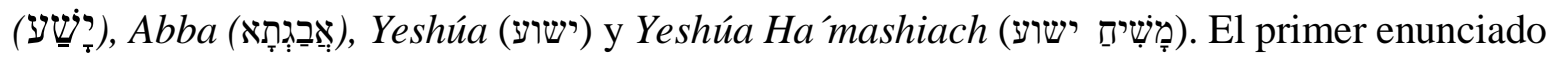
significa "Salva ahora", se utiliza como un ruego a Dios para que interceda por alguna causa;

${ }^{125}$ En el minuto 4:50, el intérprete proyecta un video en el escenario con declaraciones de sus hermanos en la fe, Pablo Fickenbinder, Alberto Motessi, Luia Palau y Víctor Richards, éste último declara que: "confiamos en tu palabra que dice, que si confesamos nuestros pecados, tú eres fiel y justo para perdonar nuestros pecados y para limpiarnos, señor."

${ }^{126}$ Símbolos como nueva criatura, serpiente, escorpiones, roca, entre otros. Mi investigación previa, de la cual hablé en la Introducción, así como mi pertenencia al cristianismo, me permiten identificar e interpretar estos símbolos, detectando las transformaciones de los mismos. 
el segundo refiere a una exclamación “¡oh padre!”; el tercero es el nombre de Jesús en hebreo; el cuarto hace referencia a Jesús como el Mesías. Estas palabras en hebreo aparecen regularmente para dotar de fuerza a los enunciados, causando mayor impacto en el enunciatario que reconoce el origen milenario de su fe.

A pesar de existir estos patrones, un rasgo común en todas las canciones es la extracción de frases textuales o paráfrasis de versículos bíblicos y a partir de ellos la composición de la letra de la pieza musical. Hay canciones que se basan en un solo versículo, pero otras se inspiran en más de cinco versículos diferentes, haciendo de cada canción un mosaico de enseñanzas y referencias bíblicas. Ejemplificando lo anterior, la tabla tres muestra algunos enunciados de la canción "Hasta acabar mi viaje" y los versículos en que se inspira:

\begin{tabular}{|c|c|c|}
\hline Canción & Enunciado & Versículos de inspiración \\
\hline \multirow{4}{*}{ Hasta acabar mi viaje } & $\begin{array}{l}\text { "Hasta ser } \\
\text { inmortalidad" }\end{array}$ & $\begin{array}{l}\text { 1ra de Corintios 15:54 "Y } \\
\text { cuando esto corruptible se haya } \\
\text { vestido de incorrupción, y esto } \\
\text { mortal se haya vestido de } \\
\text { inmortalidad, entonces se } \\
\text { cumplirá la palabra que está } \\
\text { escrita: Sorbida es la muerte en } \\
\text { victoria." }\end{array}$ \\
\hline & $\begin{array}{l}\text { "Hasta ser absorbido por mi } \\
\text { vida en ti" }\end{array}$ & $\begin{array}{l}2 \mathrm{da} \text { Corintios } 5: 4 \text { "Porque } \\
\text { asimismo los que estamos en } \\
\text { este tabernáculo gemimos con } \\
\text { angustia; porque no } \\
\text { quisiéramos ser desnudados, } \\
\text { sino revestidos, para que lo } \\
\text { mortal sea absorbido por la } \\
\text { vida." }\end{array}$ \\
\hline & $\begin{array}{l}\text { "Hasta que vea tu rostro } \\
\text { reflejado en mí" }\end{array}$ & $\begin{array}{l}\text { Números } 6: 25 \text { "Jehová haga } \\
\text { resplandecer su rostro sobre ti, } \\
\text { y tenga de ti misericordia" }\end{array}$ \\
\hline & "Voy a brillar con tu luz" & $\begin{array}{l}\text { Juan 8:12 "Otra vez Jesús les } \\
\text { habló, diciendo: Yo soy la luz } \\
\text { del mundo; el que me sigue, no } \\
\text { andará en tinieblas, sino que } \\
\text { tendrá la luz de la vida." }\end{array}$ \\
\hline
\end{tabular}

Tabla 3. Versículos de la canción "Hasta acabar mi viaje” 
Para el caso de las alabanzas, veo dos fenómenos claros en el momento en que la Biblia pasa a otros soportes y escenas enunciativas. En primera instancia, el cambio de persona, lo que responde a dos causas: la apropiación de los mensajes bíblicos que así pasan a formar parte de la vida del individuo que los enuncia y, por otro lado la modernización del mensaje bíblico, debido a la antigüedad del español de la versión Reina-Valera. En este caso es posible determinar la forma en que un grupo intenta incidir en su entorno a través de los espacios públicos y en cierta medida también se puede conocer la manera en que estos mensajes son recibidos cuando la Biblia sale de su entorno tradicional.

La naturaleza portable, lúdica y nemotécnica de las canciones potencializa la capacidad de socializar la fe por parte del creyente. Históricamente la música ha sido parte fundamental de las creencias religiosas, una característica que se cumple para el caso del cristianismo, pues cada conferencia dada en las iglesias tiene destinado un espacio de tiempo a la entonación de alabanzas, con el fin de sensibilizar al creyente y permitir que los mensajes se personalicen, dependiendo de las necesidades de la congregación. Es por eso, que el impacto de la alabanza es muy grande. Por otra parte, la frontera espacial de las alabanzas no es fija, y puede traspasar los muros de la iglesia muy fácilmente, los creyentes pueden portar sus alabanzas en cualquier momento y lugar, situando el credo en espacios comunes de creyentes y no creyentes, de modo que los enunciatarios de los enunciados contenidos en las alabanzas trascienden a los propios cristianos. 


\section{Conclusiones}

A lo largo de este recorrido argumentativo fue posible identificar el paso de elementos religiosos pertenecientes al cristianismo, que han trascendido los espacios del templo y la Biblia. Los cristianos en su consigna de propagar su fe han encontrado estrategias para hacer presentes sus preceptos en diferentes espacios y contextos. En primera instancia, las pintas en la calle muestran la versatilidad con la que se pueden representar los pasajes bíblicos, los cuales están presentes desde elementos simples como mostrar sólo el nombre de la iglesia, hasta la combinación de imágenes y texto creando murales. Estas expresiones pueden responder a la necesidad de ganar nuevos adeptos, ya que al estar presentes en el espacio público las pintas están constantemente en interacción con posibles enunciatarios que recibirán o rechazarán los pasajes plasmados en las pintas.

Por otro lado, los Tratados Chick con su componente gráfico y textual tratan de aleccionar al creyente y al no creyente sobre conceptos de toda índole, desde lo más básico, ${ }^{127}$ hasta lo más complejo. ${ }^{128}$ La oportunidad de transportar pequeñas historietas impresas o en formato digital, sin duda facilita la tarea de aleccionamiento. Además, los Tratados al representar en sus páginas situaciones cotidianas facilitan la comprensión y cercanía de enseñanzas bíblicas que en un primer momento parecerían muy lejanas en el tiempo y por lo tanto incompatibles con la cotidianidad del lector actual.

Las alabanzas se revelan como elementos lúdicos y nemotécnicos que acompañan al creyente en sus múltiples actividades a lo largo de su vida. Asimismo, son fáciles de

\footnotetext{
${ }^{127}$ Como la enseñanza de que la base de la fe cristiana es la creencia en Jesús como único y suficiente salvador.

${ }^{128}$ Como las acciones que ocurrirán en la parusía, es decir la segunda llegada de Jesús al final de los tiempos.
} 
compartir, y el ritmo, la letra o la voz del artista puede causar empatía en el enunciatario, provocando si no su conversión al cristianismo, si generando en él conocimiento de las enseñanzas del cristianismo. La versatilidad que permiten las interpretaciones en vivo posibilita la interacción entre el intérprete y el público, lo cual fortalece el vínculo existente entre el creyente y su fe.

A pesar de que en esta investigación me decidí por conformar mi corpus con estos tres elementos, existen otras manifestaciones de la fe cristiana que trascienden los espacios tradicionales del templo y las páginas de la Biblia como la radio ${ }^{129}$ y la televisión. ${ }^{130}$ Es evidente que este paso del leguaje religioso del libro y el templo al espacio público es un fenómeno complejo, en este trabajo lo que he hecho es plantearlo como un fenómeno social. Sin embargo, no puedo considerar que agoté mi objeto de estudio, es por ello que para concluir quiero incluir tres ejemplos de posibles vías de investigación que reflejan aspectos en las prácticas culturales de los cristianos vinculados a la identidad, pero es evidente que haría falta un análisis más riguroso y detallado de las formas en que se dan.

El primero tiene que ver con la utilización de un componente cristiano que funciona como símbolo de autoridad para evitar conductas indeseables. Este es el caso de la imagen 26, donde vemos que en el Salón de fiestas “Sachy”, ubicado en la delegación Iztapalapa, se observa el enunciado: "Jesucristo te ama /Respeta no pintes”, aquí es utilizado el símbolo de

\footnotetext{
${ }^{129}$ En la estación 1440 de Amplitud Modulada (AM) es posible sintonizar programas con temáticas cristianas hechos por cristianos, donde se transmiten desde conferencias y también alabanzas.

${ }^{130}$ La cadena Enlace tiene presencia a nivel mundial y cuenta con una programación cristiana durante las 24 horas los 365 días del año. Se emiten películas, programas de opinión, y conciertos, entre otros. En México, este canal sólo puede ser visto a través de la televisión de paga en los diferentes sistemas que existen (Izzi, Sky, Total Play, Megacable, por mencionar algunos).
} 
autoridad "Jesús" para tratar de evitar que personas ajenas al establecimiento pinten las paredes del salón, previniendo algún acto vandálico.

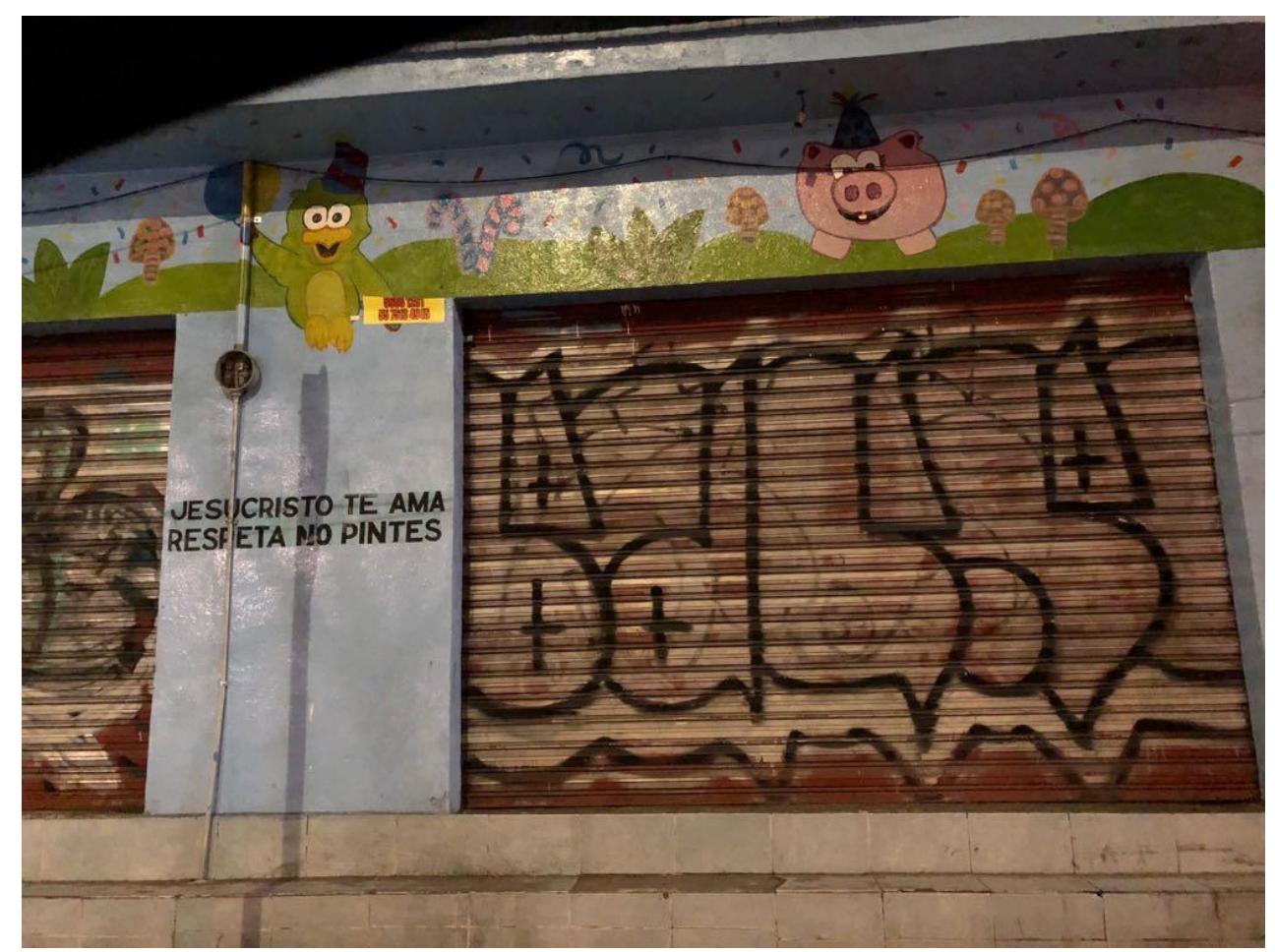

Imagen 26. Fachada del salón de fiestas "Sachy”

El enunciado refleja la ideología religiosa de los dueños del salón, en este caso, la respuesta de los grafiteros se muestra en la imagen 27 , quienes por un tiempo no pintaron en las paredes, y sólo lo hicieron en las cortinas de acero; sin embargo, las paredes terminaron siendo grafiteados. De este modo, la estrategia no fue efectiva. 


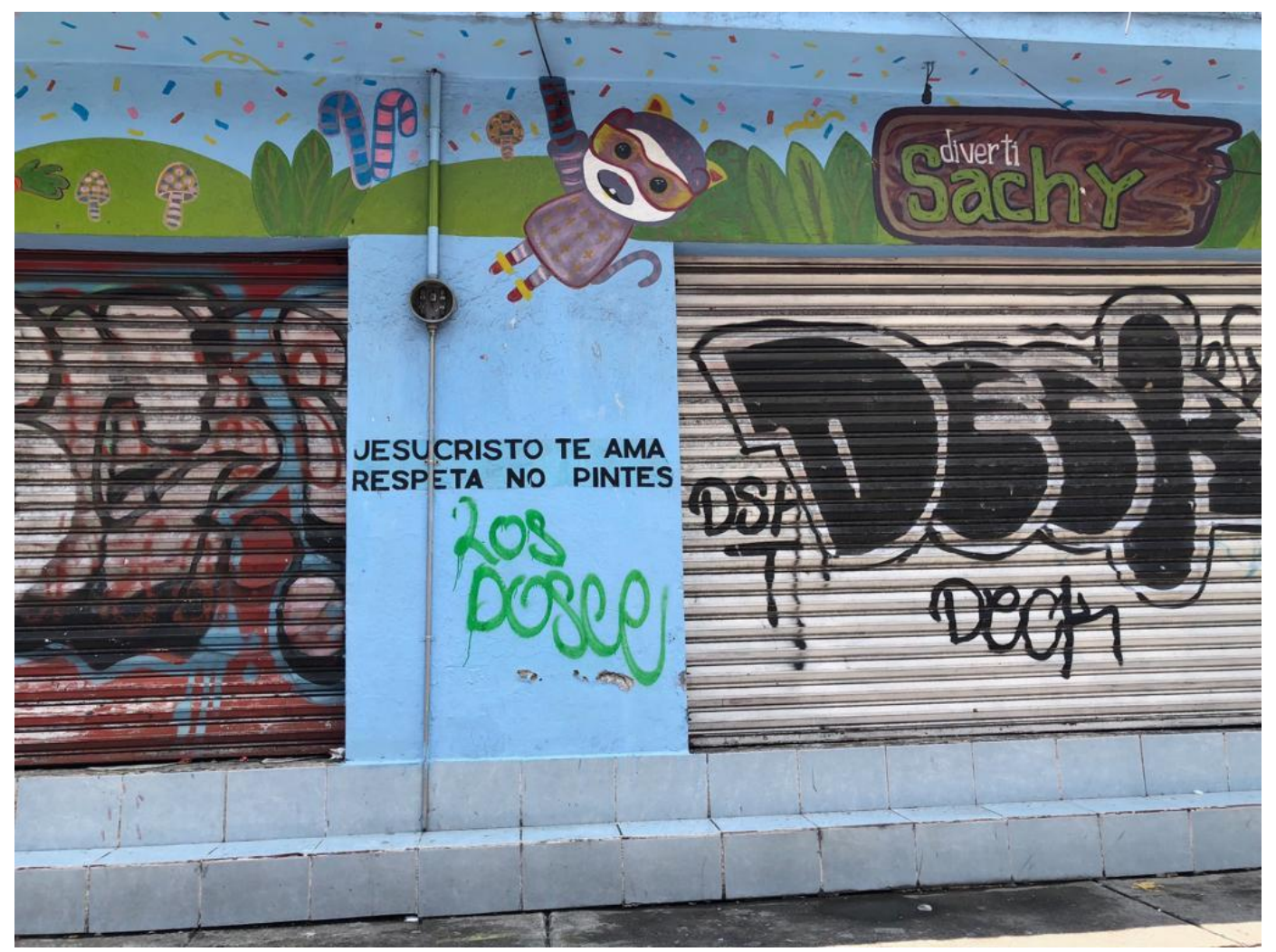

Imagen 27. Respuesta de los grafiteros al enunciado del dueño del salón de fiestas

Otro fenómeno que identifiqué es el uso del símbolo del pez como elemento de identidad, como se puede ver en la imagen 28 donde aparece una calcomanía que porta un automóvil, para mostrar la pertenencia del dueño al cristianismo. 


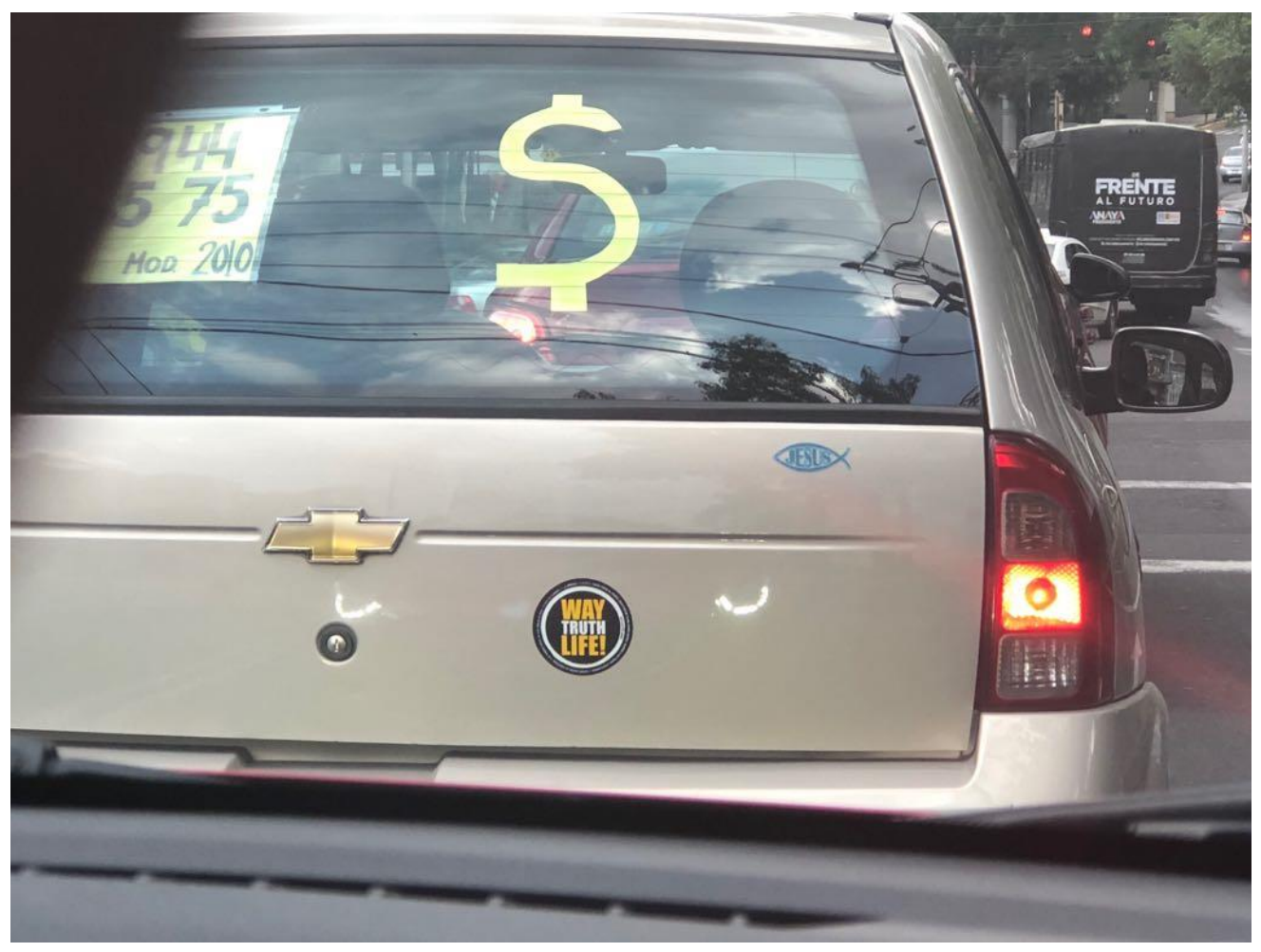

Imagen 28. Automóvil portando una calcomanía que muestra la palabra "Jesús" enmarcado en el símbolo del pez.

El símbolo del pez también aparece en algunos negocios que ostentaban el símbolo en las fachadas, con el fin de tratar de atraer a los creyentes como clientes. La imagen 29 muestra la fachada de un consultorio dental en donde se encuentra el símbolo del pez enmarcando el nombre de Jesús. En la imagen 30 se observa el símbolo del pez, pero esta vez aparece dentro de éste un versículo de la Biblia, con una nomenclatura que supone conocimiento bíblico, pues para entenderlo se debe saber que las letras representan la abreviatura del libro al que remite, el primer número se refiere al capítulo del libro y el último al versículo. 


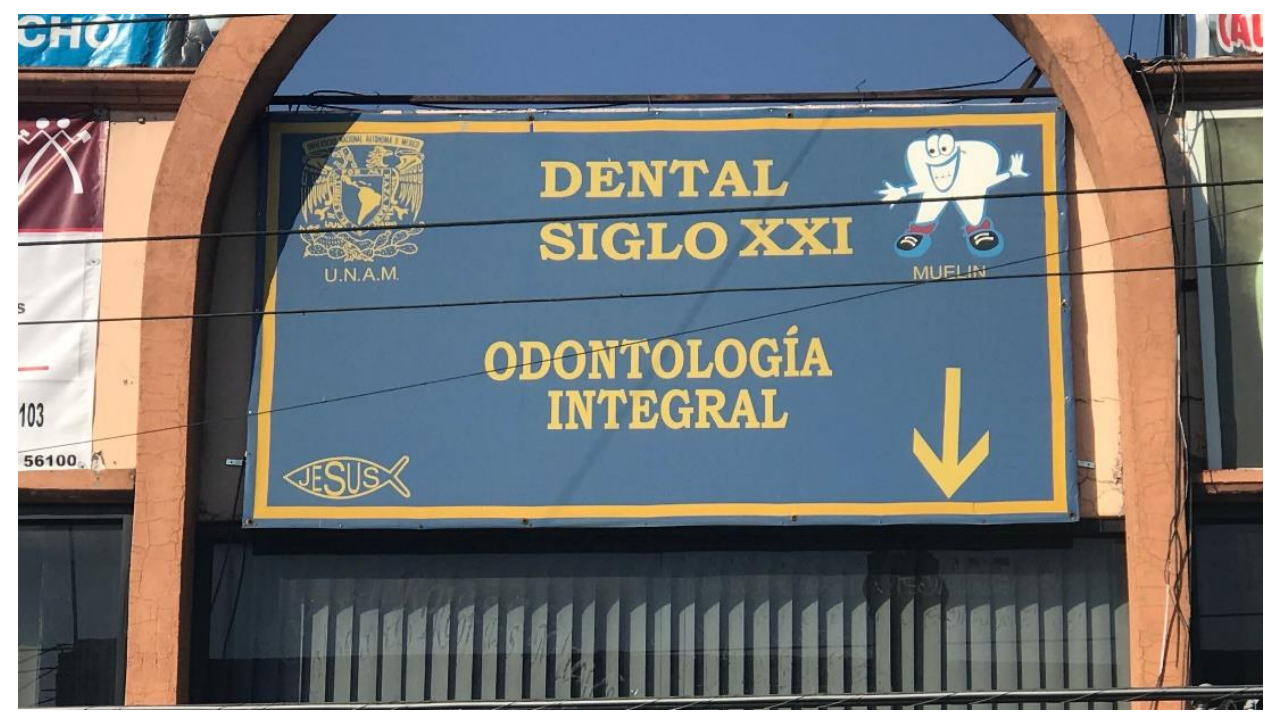

Imagen 29. Consultorio dental ubicado en Texcoco, muestra la palabra "Jesús" enmarcada en el símbolo del pez.

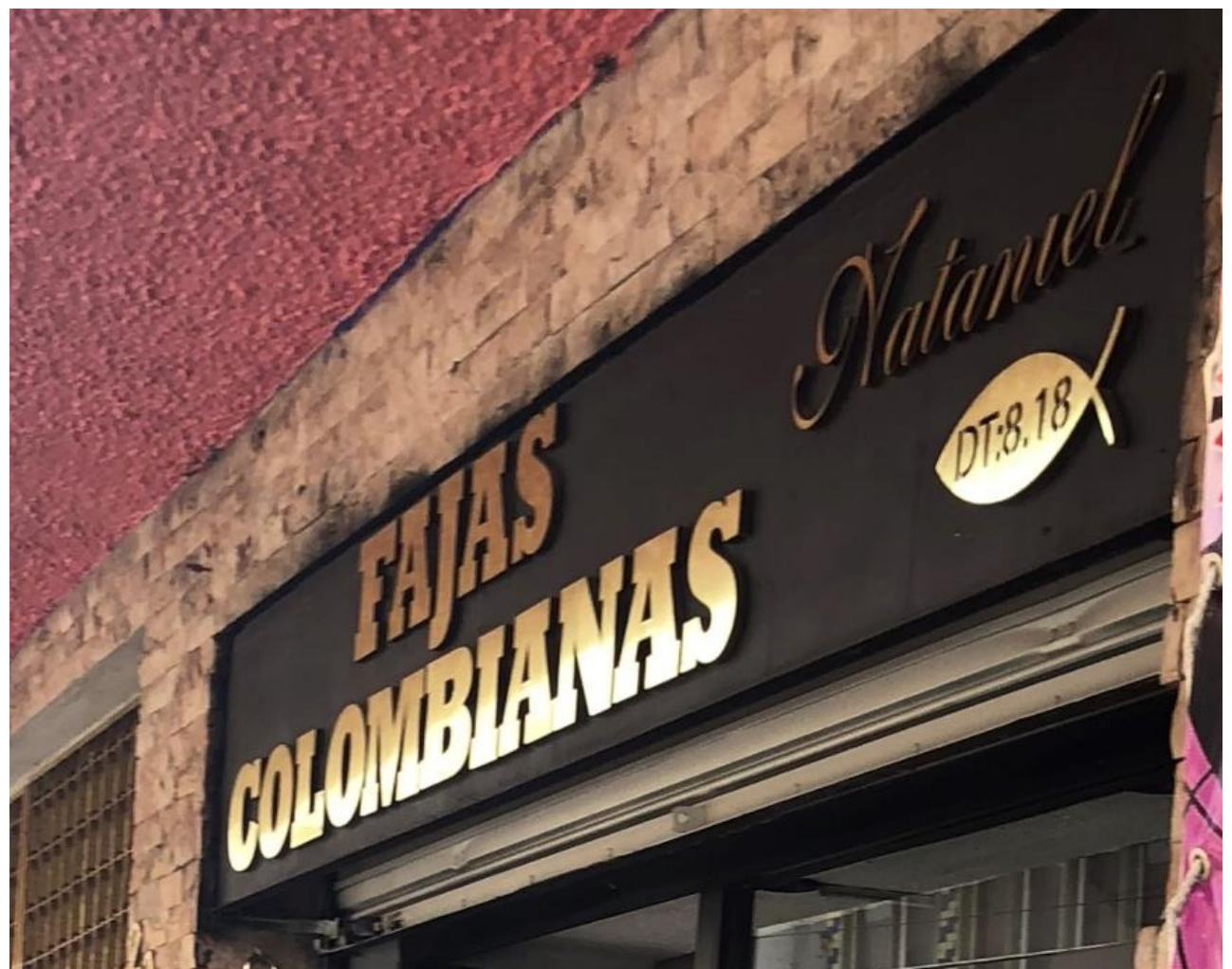

Imagen 30. Negocio de fajas ubicado en Texcoco, se muestra el símbolo del pez característico del cristianismo con un pasaje bíblico (Deuteronomio 8:18) ${ }^{131}$

${ }^{131}$ Deuteronomio 8:18: "Si no acuérdate de Jehová tu Dios, porque él te da el poder para hacer las riquezas, a fin de confirmar su pacto que juró a tus padres, como en este día." 
Otros ejemplos que me gustaría incluir, son los que encontré en el negocio llamado: “El Ruiseñor" (imagen 31), el cual se encuentra en la Central de Abastos de la ciudad de México, espacio sumamente concurrido todos los días del año. Los dueños de ese negocio decidieron bordar el uniforme de sus empleados con mensajes bíblicos, de modo que, en este caso, creyentes y no creyentes se relacionan con estos símbolos.

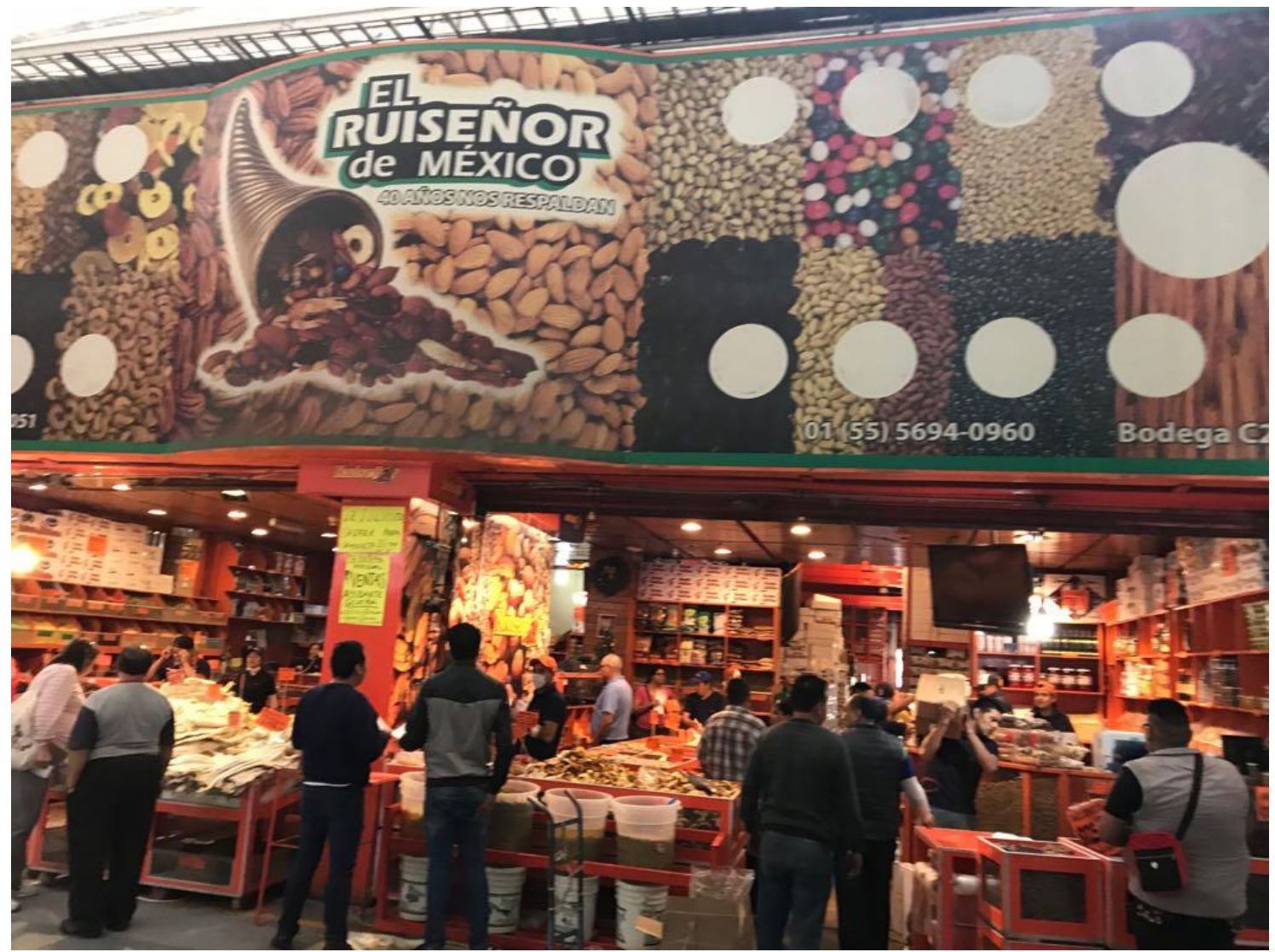

Imagen 31. Fachada del negocio "El Ruiseñor" ubicado en la central de Abastos de la Ciudad de México.

La imagen 32 muestra la parte frontal de la playera del uniforme de una empleada, la prenda tiene el símbolo del pez rodeado del texto salmista $18: 16,{ }^{132}$ en este caso se cita el versículo sin abreviar el nombre del libro. En la imagen 33 se puede apreciar la parte trasera de la playera que conforma el uniforme, donde se aprecia el texto de un versículo bíblico, sin indicar que se trata del versículo 2 del Salmo 14.

\footnotetext{
132 Salmo 18:16 "Salmo 18:18 Extendió su mano desde lo alto, tomó la mía y me saco del mar profundo."
} 


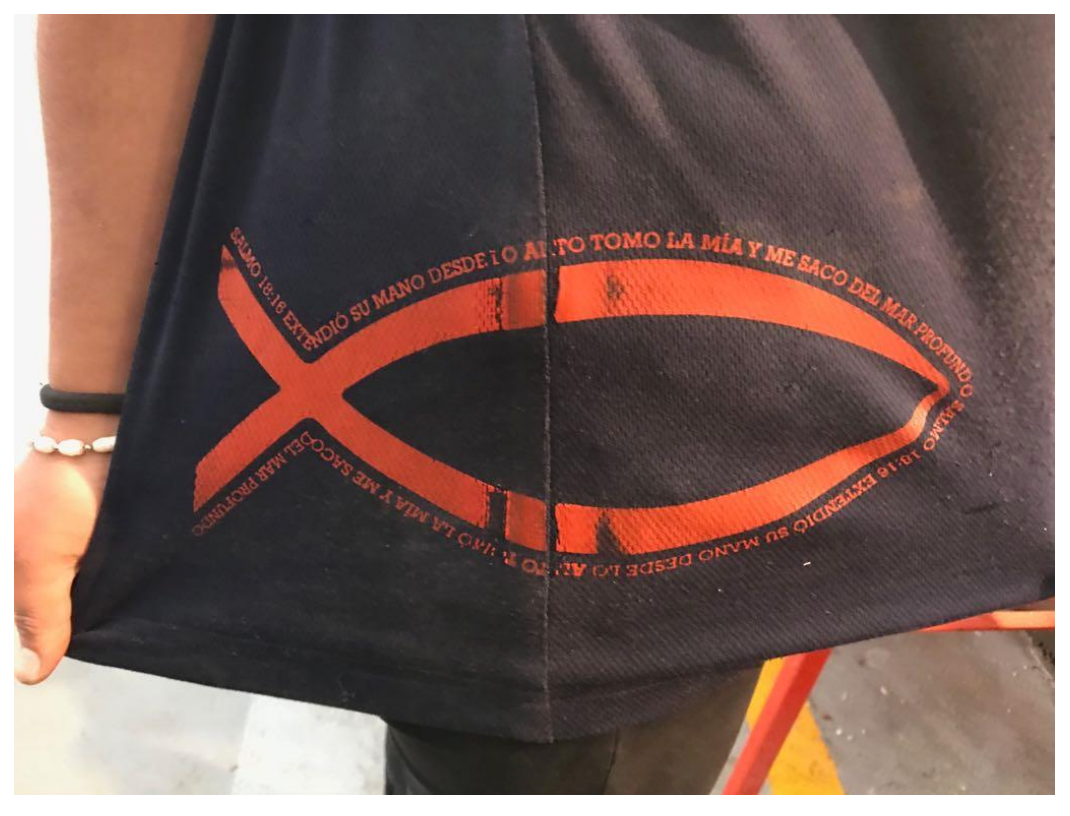

Imagen 32. Frente de la playera del uniforme de una empleada del "Ruiseñor"

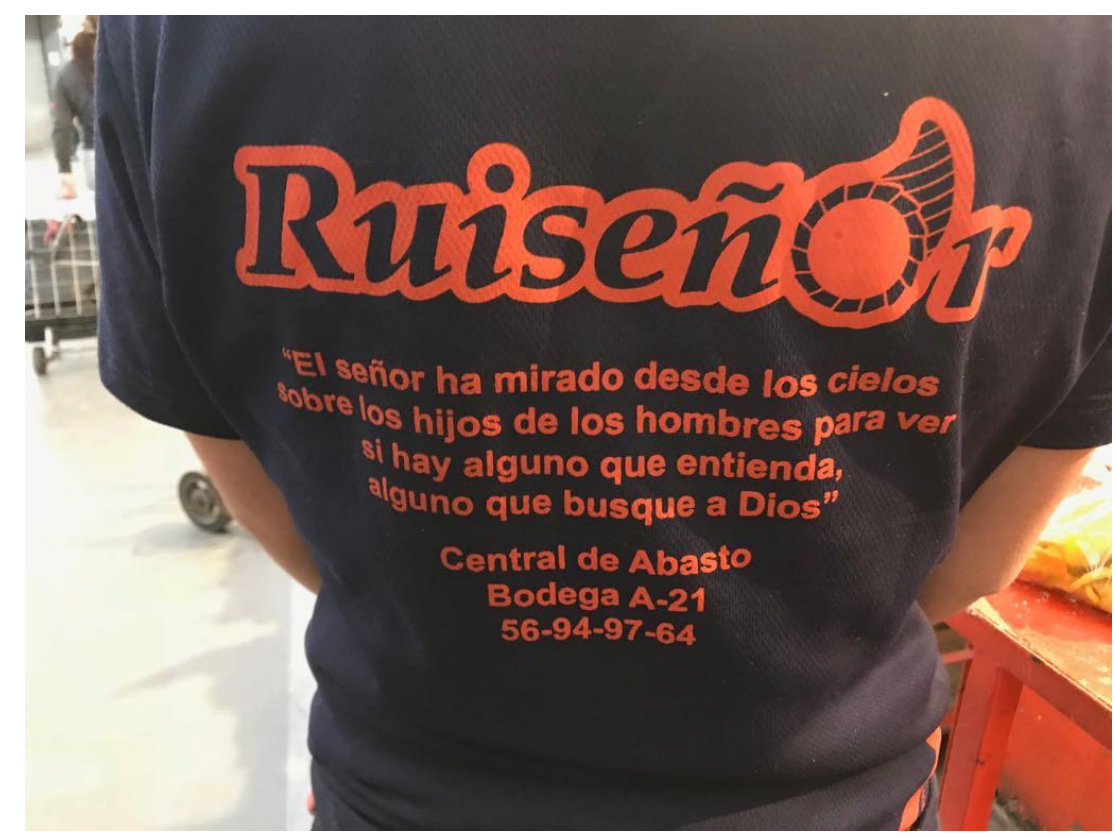

Imagen 33. Reverso de la playera del uniforme de una empleada del "Ruiseñor"

Por último, la imagen 34 muestra la parte trasera de la gorra que también forma parte del uniforme de los empleados de este establecimiento, en ella es posible apreciar un 
versículo bíblico, donde se reproduce el texto y se indica el libro bíblico sin abreviaturas, el número del capítulo y del versículo.

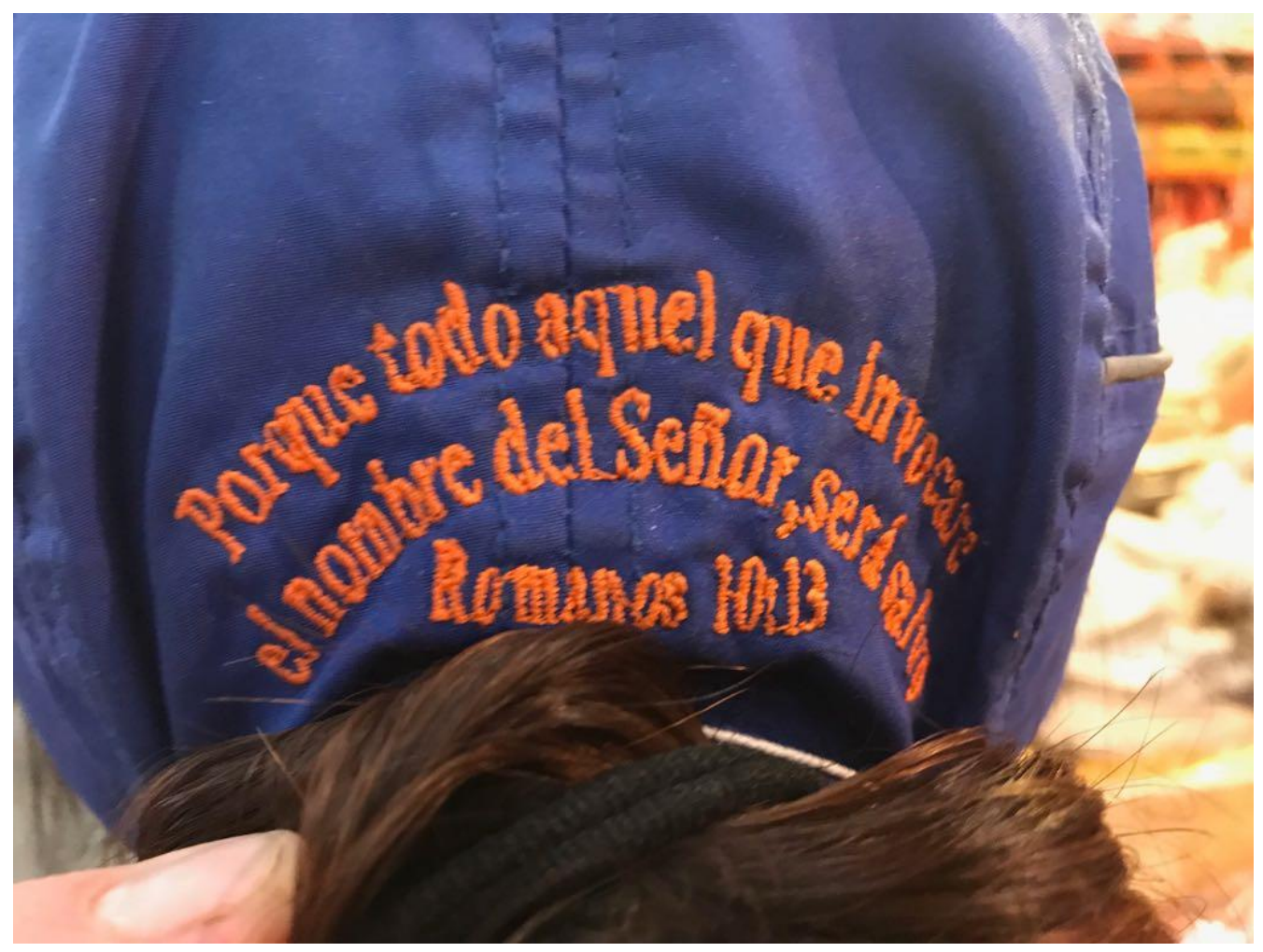

Imagen 34. Reverso de la gorra del uniforme de una empleada del "Ruiseñor"

Esta práctica por parte de los creyentes de adoptar y mostrar símbolos que reflejan su identidad, trascendiendo los espacios tradicionales de la iglesia, muestra la existencia de una especie de identidad lingüística que sirve para ser reconocido como cristiano, es decir, como: "el vínculo que crea el individuo con la comunidad de habla de la que se hace miembro y cuya variedad de lengua adopta como suya propia."133

Con la conformación de esta identidad lingüística cada uno de los creyentes es parte de una comunidad lingüística en la que sus miembros se reconocen e interactúan entre ellos:

\footnotetext{
${ }^{133}$ Hernán Martínez Matos y Elsa Mora, "La identidad lingüística y los trastornos del habla", en Boletín de Lingüística, vol. 20, núm. 29, junio 2008, p. 88.
} 
"No hay límites a las formas en que los seres humanos se asocian para la auto-identificación, seguridad, logros, diversiones, celebraciones, o cualquier otra clase de propósitos comunes; consecuentemente, no hay límite al número y variedad de comunidades lingüísticas que puedan darse en la sociedad." ${ }^{134}$ Hay que dejar en claro que los cristianos no dejan de ser cristianos al momento de abandonar sus congregaciones, su fe se convierte en un estilo de vida en todos los espacios en los que se desarrollan como individuos; una característica que dificulta el estudio de este grupo social, pero que al mismo tiempo lo convierte en un objeto de estudio muy interesante.

Como parte de la vida cotidiana, vemos el uso de elementos simbólicos e icónicos en establecimientos públicos proyectando un mensaje de pertenencia e identidad como creyente. Es posible observar que la utilización de estos símbolos cumple, por lo menos con dos objetivos. En primer lugar identificarse como cristianos y en segundo término, alcanzar un fin comercial, puesto que el objetivo es atraer a otros creyentes que sientan afinidad y confianza al comprar o acudir a establecimientos de personas que comparten su fe.

Cabe señalar que el uso de estos símbolos no es homogéneo, sin embargo, la estrategia de buscar nuevas formas para mostrar preceptos del cristianismo es común en los creyentes de esta fe. Desde los primeros tiempos del cristianismo hasta nuestros vemos la capacidad de adaptación que tiene esta religión, puesto que la idea que defienden los creyentes de considerar su fe como un estilo de vida posibilita la presencia de elementos religiosos más allá de la iglesia y la propia Biblia.

${ }^{134}$ Richard Hudson, La sociolingüística, Barcelona, Anagrama, 1981, p. 38. 
Esta investigación me sirvió para darme cuenta de la posibilidad de unir conceptos de distintas disciplinas como la lingüística, la antropología, la historia y la etnografía, ya que, en mi caso, cada una de las disciplinas me sirvieron para dar cuenta de alguna característica del cristianismo y sus prácticas de socialización de la fe. La versatilidad del lenguaje se vio reflejada en cada uno de los elementos de mi corpus, aunque como ya mencioné anteriormente todavía es posible ahondar más sobre el uso de los símbolos, las prácticas de identidad, la afinidad o la resistencia de cada denominación del cristianismo al momento de socializar su fe. En suma, el lenguaje como producto de las prácticas culturales enriquece y complementa las visiones lingüísticas que se enfocan solamente en lo gramatical. 


\section{Bibliografía}

Agamben, Giorgio, “¿Qué es un dispositivo?”, en Sociología, número 73, mayo-agosto 2011, pp. 249-264.

Augé, Marc, Los no lugares. Espacios de anonimato. Una antropología de la sobremodernidad, Barcelona, Gedisa, 2000.

Bascom, Roberto, Daniel Bonilla, et al., «Enseñaba por parábolas... »Estudio del género «parábola »en la Biblia, México, Editado por Edesio Sánchez Cetina, 2003.

Bajtín, Mijaíl, Estética de la creación verbal, México, Siglo XXI, 1999.

Benveniste, Émile, Problemas de lingüística general II, México, Siglo XXI, 1983.

Bourdieu, Pierre, ¿Qué significa hablar? Economía de los intercambios lingüísticos, Madrid, Akal, 1985.

Cortés Peña, Antonio Luis (coord.), Historia del cristianismo III. El mundo moderno, Madrid,Trotta, 2006.

Culler, Jonathan, "Hacia una lingüística de la escritura", en Nigel Fabb, Derek Attridge, Alan Durant y Colin MacCabe (comps.), La lingüística de la escritura. Debates entre lengua y literatura, Madrid, Visor, 1989, pp. 181-192.

De la Torre, Renée y Cristina Gutiérrez Zuñiga (coords.), Atlas de la diversidad religiosa en México, México, CIESAS-El Colegio de Jalisco-El Colegio de la Frontera Norte-El Colegio de Michoacán-Universidad de Quintana Roo-Secretaría de Gobernación-CONACYT, 2007

Díaz de Rada, Ángel, Cultura, antropología y otras tonterías, Madrid, Trotta, 2010.

"Edicto de Milán", en Miguel Artola, Textos fundamentales para la historia, Madrid, Alianza, 1978, p.21.

"Edicto de Tesalónica“, en Miguel Artola, Textos fundamentales para la historia, Madrid, Alianza, 1978, pp.22-23.

Flavio Josefo, La guerra de los judíos, México, Porrúa, 2008.

Foucault, Michel, La arqueología del saber, Siglo XXI, México, 1970.

Garma Navarro, Carlos, "La socialización del don de lenguas y la sanación en el pentecostalismo mexicano", en Alteridades, núm. 10, 2000, p. 85-92. 
, Buscando el espíritu. Pentecostalismo en Iztapalapa y la ciudad de México, México, Universidad Autónoma Metropolitana. Unidad Iztapalapa/Plaza y Valdés Editores, 2004.

, y Virginia Garrard Burheh, "Protestantism in Mexico", en John Bowden (ed.), Encyclopedia of Christianity, Nueva York, Oxford Univesity Press, 2006, pp. $1-9$.

, "Las masculinidades en la música cristiana", en Franco Savarino y Alejandro Pinet (coords), Movimientos sociales. Estado y religión en América Latina. Siglos XIX y XX, México, PROMEP-INAH-CONACULTA, 2009, p. 71-87.

Grau Tello, María Luisa, "La pintura mural en el espacio urbano", en Revista de Andorra, núm. 8, 2009, pp. 259-273.

Guiraud, Pierre, La semiología, México, Siglo XXI, 1972.

Gutiérrez Zúñiga, Cristina, "El protestantismo histórico", en Renée De la Torre y Cristina Gutiérrez Zuñiga (coords.), Atlas de la diversidad religiosa en México, México, CIESAS-El Colegio de Jalisco-El Colegio de la Frontera Norte-El Colegio de Michoacán-Universidad de Quintana Roo-Secretaría de Gobernación-CONACYT, 2007, pp. 50-60.

Hudson, Richard, La sociolingüística, Barcelona, Anagrama, 1981.

Lozano, Armind y Emilio Mitre, Análisis y comentarios de textos-históricos I. Edad Antigua y Media, Madrid, Alhambra, 1984.

Martínez Matos, Hernán y Elsa Mora, "La identidad lingüística y los trastornos del habla", en Boletín de Lingüística, vol. 20, núm. 29, junio 2008, pp. 85-101.

Martínez Rodríguez, Marcela, "El proyecto colonizador de México a finales del siglo XIX. Algunas perspectivas comparativas en Latinoamérica", en Secuencia, núm. 76, enero/abril 2010, pp. 103-132.

Mitre Fernández, Emilio (coord.), Historia del cristianismo II. El mundo medieval, Madrid, Trotta, 2006.

Quezada, Claudia Julieta, "La mujer cristera en Michoacán, 1926-1929”, en Historia y Memoria, núm. 4, 2012, pp. 191-223.

Sotomayor, Manuel y José Fernández Ubiña (coords.), Historia del cristianismo I. El mundo antiguo, Madrid, Trotta, 2003.

Strano, Silvino, "En torno a las catacumbas cristianas de Roma: historia y aspectos iconográficos de sus pinturas", en Boletín de Arte, núm. 26-27, 2005-2006, pp. 17-31. 
Strong, James, Nueva concordancia STRONG EXHAUSTIVA, Nashville/Dallas/México/Río de Janeiro/Beijing, Grupo Nelson, 1890/2002.

Wittgenstein, Ludwig, Lecciones y conversaciones sobre estética, psicología y creencia religiosa, Barcelona/Buenos Aires/México, Ediciones Paidós/Universidad Autónoma de Barcelona, 1992.

Yule, George, El lenguaje, Madrid, Akal, 2008.

\section{Fuentes electrónicas}

Belmont, José Antonio, “AMLO, a punto de conquistar la tierra prometida: Hugo Éric Flores" en Milenio, disponible en http://www.milenio.com/politica/amlo-punto-conquistartierra-prometida-hugo-eric-flores (consultado el 30 de agosto de 2018).

Convención Nacional Bautista de México A.R, "Principios bíblicos" disponible en https://drive.google.com/file/d/0B7QqmoT3PPhsSVRHVVhfRGpLNFE/edit (consultado el 18 de junio de 2018).

Disciplina de la Iglesia Metodista de México, pp. 237-238. Disponible en http://iglesiametodista.org.mx/creemos.html (consultado el 19 de junio de 2018).

Domínguez, Pedro, "No somos un partido religioso", en Milenio, 10 de febrero de 2014, disponible en http://www.milenio.com/politica/partido-religioso-contrario-liberalesdirigente-encuentro-social (consultado el 15 de junio de 2018).

García Garate, Iván, "Los contenidos sustanciales de la libertad de religión se definen por la Constitución y por tratados internacionales de derechos humanos interpretados por los órganos jurisdiccionales competentes. No por la Iglesia", en Letras Libres, 21 de marzo de 2012, disponible en http://www.letraslibres.com/mexico-espana/religion-yconstitucionalismo-mexicano (consultado el 15 de junio de 2018).

Hernández Hernández, Alberto, Cristina Gutiérrez Zúñiga y Renée de la Torre Castellanos (coords.), "Encuesta Nacional sobre Creencias y Prácticas Religiosas" realizada en 2016 por la Red de Investigadores del Fenómeno Religioso en México (RIFREM), disponible en http://www.rifrem.mx/?publicacion=encuesta-nacional-en-mexico-sobre-creencias-ypracticas-religiosas (consultado el 4 de febrero de 2018).

Informe de pobreza y evaluación en el Distrito Federal 2012, Disponible en https://www.coneval.org.mx/coordinacion/entidades/Documents/Informes\%20de\%20pobre za\%20y\%20evaluaci\%C3\%B3n\%202010-

2012_Documentos/Informe\%20de\%20pobreza\%20y\%20evaluaci\%C3\%B3n\%202012_Dist rito\%20Federal.pdf (consultado el 18 de noviembre de 2017). 
"Ley sobre libertad de cultos 4 de diciembre de 1860", Disponible en http://www.anfade.org.mx/docs/ponencias/Leysobrelibertadcultos_Anexo13.pdf (consultado el 20 enero de 2018).

Lutero, Martín, Las 95 tesis, disponible en http://www.fiet.com.ar/articulo/95_tesis.pdf (consultado el 15 de febrero de 2018).

Pele, Alina, Las distribuciones vocales en coros Góspel: percepción de coristas y oyentes, (tesis doctoral) en https://riunet.upv.es/bitstream/handle/10251/30775/Tesis\%20completa\%20Alina\%20Leuci an $\% 20$ Pele $\% 20$ con $\% 20$ resumenes.pdf?sequence $=1$ (consultada el 2 de noviembre de 2018).

Schuster, Juan, "Antecedentes históricos de la penetración protestante en México", Disponible en http://cdigital.uv.mx/bitstream/123456789/2263/2/198658P12.pdf (consultado el 20 de enero 2018). 
Hablan Biblia: el lenguaje religioso de los cristianos más allá de la Biblia y del Templo.
En la Ciudad de México, se presentaron a las 10:00 horas del día 11 del mes de enero del año 2019 en la Unidad Iztapalapa de la Universidad Autónoma Metropolitana, los suscritos miembros del jurado:

DRA. LAURA ADRIANA HERNANDEZ MARTINEZ

MTRO. ROBERTO AGUNDEZ MARQUEZ

DRA. MA. DEL REFUGIO PEREZ PAREDES

Bajo la Presidencia de la primera y con carácter de Secretaria la última, se reunieron para proceder al Examen de Grado cuya denominación aparece al margen, para la obtención del grado de:

MAESTRA EN HUMANIDADES (LINGUISTICA)

DE: DULCE MARIANA CORONEL AGUILAR

$y$ de acuerdo con el artículo 78 fracción III del Reglamento de Estudios Superiores de la Universidad Autónoma Metropolitana, los miembros del jurado resolvieron:

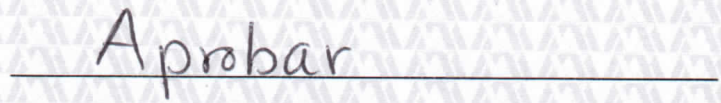

Acto continuo, la presidenta del jurado comunicó a la interesada el resultado de la evaluación y, en caso aprobatorio, le fue tomada la protesta.
MTRA/ROSALIA SERRANO DE LAPAZ DIRECTORA DE SUST FMAS ESCOLARES
DULCE MARIANA CORONEL AGUILAR ALUMNA

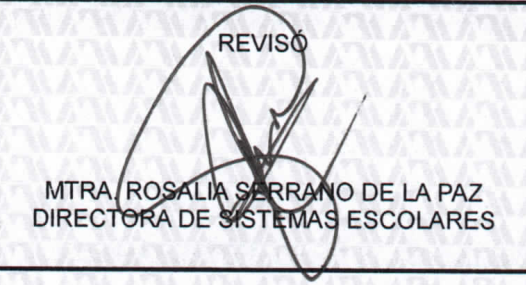

DIRECTOR DE LA DIVISIÓN DE CSH
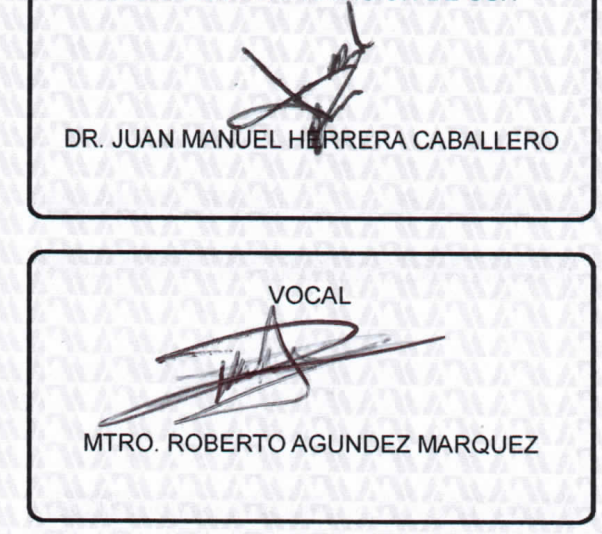
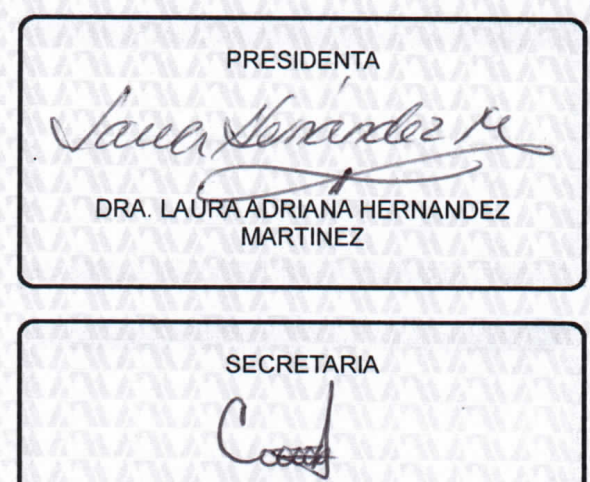

DRA. MA. DEL REFUGIO PEREZ PAREDES 